VIVIANE FRAGOSO DE MOURA LANE

\title{
ANÁLISE EPIDEMIOLÓGICA DA LEISHMANIOSE VISCERAL HUMANA NO BRASIL: CONTRIBUIÇÃO ÀS POLITICAS DE CONTROLE
}




\author{
Universidade de Brasília \\ Faculdade de Medicina \\ Programa de Pós-Graduação em Ciências Médicas
}

VIVIANE FRAGOSO DE MOURA LANE

\title{
ANÁLISE EPIDEMIOLÓGICA DA LEISHMANIOSE VISCERAL HUMANA NO BRASIL: CONTRIBUIÇÃO ÀS POLITICAS DE CONTROLE
}

Tese de Doutorado apresentada ao Programa de Pós-Graduação em Ciências Médicas como requisito parcial para obtenção do Título de Doutor em Ciências aplicadas à Saúde pelo Programa em Ciências Médicas da Universidade de Brasília-UNB

Orientador: Prof. Dr. Vitor Laerte Pinto Júnior 
Ficha catalográfica elaborada automaticamente,

com os dados fornecidos pelo(a) autor(a)

Fragoso de Moura Lane, Viviane Fragoso de Moura Lan Analise Epidemiologica da Leishmaniose Viscer

Viviane Fragoso de Moura Lane Fragoso de Moura Lane; orientador Vitor Laerte Pinto Júnior. .. Brasillia. 2016.

$158 \mathrm{p}$.

Tese (Doutorado - Doutorado em Ciências Médicas) - Universidade de Brasilia, 2016.

1. Judicialização da saúde; Leishmaniose Visceral Humana; Epidemiologia. 2. Atenção Primaria à Saúde; Prevençăo e Controle. 3. Urbanização. I. Laerte Pinto Júnior, Vitor, orient. II. Título. 


\section{ANALÍSE EPIDEMIOLÓGICA DA LEISHMANIOSE VISCERAL HUMANA NO BRASIL: CONTRIBUIÇÃO AS POLÍTICAS DE CONTROLE}

Tese de Doutorado apresentada ao Programa de Pós-Graduação em Ciências Médicas como requisito parcial para obtenção do Título de Doutor em Ciências aplicadas à Saúde pelo Programa em Ciências Médicas da Universidade de Brasília-UNB

Aprovado em 26/02/2016

\section{BANCA EXAMINADORA}

(Presidente)

Vitor Laerte Pinto Júnior

(Fiocruz)

Dra. Mariana Machado Hecht

(UnB)

Dra. Maria Célia Delduque

(Fiocruz)

Dra. Isabele Barbieri dos Santos

(Fiocruz)

Dr. Adriano Almeida de Lima

(UnB)

Dra. Maria do Socorro Natua Evangelista (UnB)

(Suplente) 


\section{DEDICATÓRIA}

Dedico este trabalho aos meus pais, Francisca Fragoso de Moura e Pedro José de Moura, por serem o alicerce necessário e aplausos em minhas conquistas. 
"Por vezes sentimos que aquilo que fazemos não é senão uma gota de água no mar. Mas o mar seria menor se lhe faltasse uma gota" (Madre Teresa de Calcutá) 


\section{AGRADECIMENTOS}

Agradeço a todos que de alguma maneira contribuíram para elaboração deste trabalho:

Ao meu orientador, Prof. Dr. Vitor Laerte Pinto Júnior, pelos valiosos ensinamentos, paciência e dedicação no decorrer da elaboração da tese. A ele, minha admiração, por ser um exemplo de profissionalismo.

À Diretoria de Atenção Primária-DIRAPS do Hospital Regional de Sobradinho, em especial ao Dr. Cleiton e a Enfermeira Iris Silva, por oportunizar a execução de parte deste trabalho.

Às equipes da estratégia Saúde da Família-ESF, da região administrativa da Fercal - DF: comunidades do Engenho Velho,Queima Lençol e Rua do Mato, pelo apoio técnico no trabalho de campo.

À Dra Isabele Barbieri Santos, pelas discussões e incentivo na elaboração deste trabalho.

Ao Prof. Dr. Cesar Carranza-Tamayo, pelas discussões e apoio ao trabalho.

À Dra Denise Furlanetto, pelo apoio e incentivo na reta final deste trabalho.

À CAPES, pelo financiamento, com a concessão de bolsa de estudos.

Aos membros da banca, pela cordialidade, de terem aceitado participar da discussão da minha tese.

Às minhas amigas, Norma Paes Santos e Cristiane Citadin, pela amizade verdadeira de sempre.

Aos meus pais, pelo apoio incondicional e por sempre ter valorizado a minha formação.

Aos meus irmãos, Pedro José de Moura Júnior e Alexandre Fragoso de Moura pelo apoio necessário.

Ao meu esposo, Marcus Vinícius Lane de Abreu, pelo companheirismo. Amo-te!

Ao meu filho e príncipe, Arthur Fragoso de Abreu, que apesar de pequeno, é luz em muitos momentos e de uma compreensão admirável.

Por fim, a Deus pela oportunidade de executar este trabalho, vencer obstáculos e superar os desafios. 


\section{RESUMO}

Esta tese tem como objetivo contribuir para o entendimento dos aspectos determinantes da Leishmaniose visceral como problema de saúde pública no Brasil. Para este fim, foram delineados quatro estudos: o primeiro se propôs a descrever a judicialização das ações direcionadas ao reservatório canino, um dos pilares de controle da LV no Brasil. Analisou-se Termos de Ajustamento de Conduta e de Ações Judiciais relativas à LV. Constatou-se um comportamento hiperendêmico da LV nas capitais de Belo Horizonte, Campo Grande, Fortaleza e Palmas. Além disso, verificou-se que a interferência do Ministério Público direcionadas ao reservatório doméstico, colabora para a descontinuidade das ações de controle da doença. No segundo estudo, analisou-se o conhecimento e práticas profissionais no âmbito da atenção primária e a atenção aos casos diagnosticados em um território endêmico do Distrito Federal. Realizou-se um descritivo exploratório e quantitativo. Aplicou-se um questionário estruturado aos profissionais de saúde pertencentes às unidades de atenção básica. Apesar dos participantes revelarem a importância epidemiológica da LVH na região, demonstrou-se que essas regiões apresentam dificuldades operacionais, as quais dificultam a execução de ações direcionadas aos casos de LV. No terceiro estudo realizou-se uma série de casos, entre 2011 a 2014, em um território endêmico do Distrito Federal, cuja finalidade foi acompanhar a evolução da doença em pacientes com teste Montenegro positivo, além de analisar a dinâmica de transmissão no local. Conclui-se, portanto, que o entendimento acerca da progressão de indivíduos assintomáticos, em áreas endêmicas, não depende apenas da confirmação de casos por meio de testes diagnósticos, mas também da dinâmica de transmissão no local. Por fim, o último estudo teve o intuito de compreender o processo que consolidou a urbanização da LV no Brasil, criou-se uma narrativa histórica da epidemiologia da doença agregando informações que possam criar hipóteses para o entendimento da LV urbana e também medidas de controle mais efetivas. $\mathrm{O}$ advento da industrialização no país motivou o êxodo rural permitindo mudanças demográficas com o crescimento populacional. O fenômeno atual deveu-se a criação de condições ideais para a manutenção do ciclo de transmissão nas cidades brasileiras. Além deste fato, a descontinuidade das ações de controle foi relevante para a determinação de epidemias urbanas. Ao considerar o cenário epidemiológico atual da LV, é necessário que seja considerado um planejamento urbano nas cidades e não apenas estratégias centradas na dinâmica de transmissão da doença para que se tenha um impacto positivo na epidemiologia da LV. 
Palavras-Chave: Leishmaniose Visceral, Judicialização, epidemiologia, Atenção Primária à Saúde, inquéritos epidemiológicos, Urbanização. 


\begin{abstract}
This thesis aims to contribute to the understanding of the determinants of the Visceral leishmaniasis as a public health problem in Brazil. To this end, four studies were outlined: the first proposed to describe the legalization of actions directed to the canine reservoir, one of the LV control pillars in Brazil. It analyzed Terms of Conduct Adjustment and lawsuits related to LV. It found a hyperendemic behavior of LV in the cities of Belo Horizonte, Campo Grande, Fortaleza and Palmas. Moreover, it was found that the interference of the prosecution aimed at the domestic reservoir, contributes to the discontinuance of the disease control measures. In the second study, we analyzed the professional knowledge and practice within primary care and attention to cases diagnosed in an endemic area of the Federal District. We conducted an exploratory and quantitative descriptive. Applied a structured questionnaire for health professionals belonging to the primary care units. Although the participants reveal the epidemiological importance of LVH in the region, it was shown that these regions present operational difficulties, which hinder the implementation of actions directed to cases of VL. In the third study a number of cases took place between 2011 to 2014 in an endemic area of the Federal District, whose purpose was to monitor the evolution of the disease in patients with positive Montenegro test, and analyze the dynamics of transmission in place. It follows therefore that the understanding of the progression of asymptomatic individuals in endemic areas, not only dependent on the confirmation of cases by diagnostic tests, but also the dynamic transmission on site. Finally, the latest study aimed to understand the process that consolidated the urbanization of VL in Brazil, created a historical narrative of the epidemiology of the disease adding information that can create hypotheses for understanding the urban LV and also control measures more effective. The advent of industrialization in the country motivated the rural exodus allowing demographic changes with population growth. The current phenomenon was due to the creation of ideal conditions for maintaining the transmission cycle in Brazilian cities. In addition to this fact, the discontinuity of control actions was relevant to the determination of urban epidemics. When considering the current epidemiological situation of the LV, it must be considered an urban planning in cities and not just centered strategies in the transmission dynamics of the disease in order to have a positive impact on the epidemiology of VL.
\end{abstract}

Keywords: Leishmaniasis, Visceral, judicialization, epidemiology, Primary Care, Health Surveys, Urbanization. 


\section{ÍNDICE DE FIGURAS}

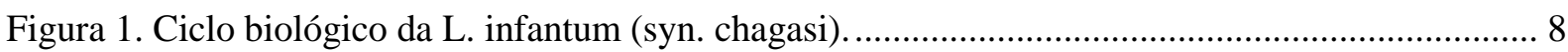

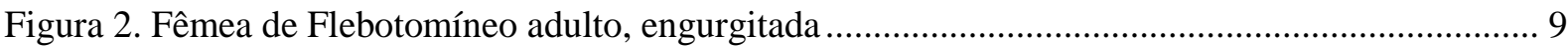

Figura 3. Distribuição dos vetores da Leishmaniose Visceral na região Centro-Oeste do Brasil ......... 11

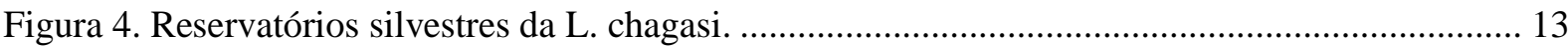

Figura 5. Distribuição Geográfica de Leishmaniose Visceral-LV no Mundo, 2012 ............................. 17

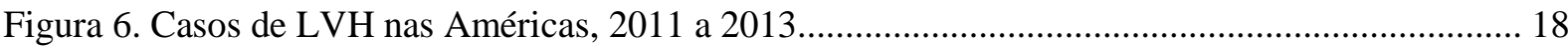

Figura 7. Expansão da Leishmaniose Visceral Humana no Brasil (1981-2009)................................... 21

Figura 8. Eco-epidemiologia da LV no estado do Pará, norte do Brasil................................................ 23

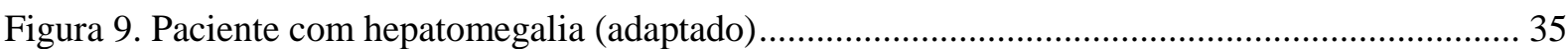

Figura 10. Localização das regiões de Sobradinho I e II e a região da Fercal ...................................... 55 


\section{LISTA DE ABREVIATURAS E SIGLAS}

\begin{tabular}{|c|c|}
\hline APA & Área de Proteção Ambiental \\
\hline CAPES & Coordenação de Aperfeiçoamento de Pessoal \\
\hline CEP & Comitê de Ética em Pesquisa \\
\hline DF & Distrito Federal \\
\hline ELISA & Ensaio imunoenzimático \\
\hline ESF & Estratégia Saúde da Família \\
\hline gp63 & Proteína de Membrana de Superfície \\
\hline CRK3 & Ciclina dependente de quinase \\
\hline CR1/3 & Receptor para complemento do tipo 1 e 3 . \\
\hline CD4 & Linfócito $\mathrm{T}$ auxiliares \\
\hline CD8 & Linfócito T citotoxico \\
\hline HIV & do inglês, Human Immunodeficiency Virus \\
\hline $\mathbf{H}_{2} \mathbf{O}_{2}$ & Peróxido de Hidrogênio \\
\hline IDRM & Intradermoreação de Montenegro \\
\hline IgG/E/M & Imunoglobulinas das classes G,E e M. \\
\hline IL/2 & Interleucina 2 \\
\hline IL/8 & Interleucina 8 \\
\hline IL/10 & Interleucina 10 \\
\hline IL/12 & Interleucina 12 \\
\hline iNOS & Óxido Nítrico Sintetase \\
\hline IFN $\lambda$ & Inferferon-gama \\
\hline IFNa & Interferon-alfa \\
\hline Kda & Kilodalton \\
\hline kDNA & DNA circular do cinetoplasto \\
\hline
\end{tabular}


LVH

LVC

LV

LTA

L.chagasi

L. major

L. evansi

L. donovani

L.amazonensis

L. brasizilienses

L. chagasi

L.(L.)chagasi

L.(L) infantum

L. longipalpis

Lu. forratini

Lu. almerioi

Lu. ayrozai

Lu. neivai

Lu. fischeri

KArex

Lamp

LPG

NASBA

OMS

WHO

ONG's

PCR
Leishmaniose Visceral Humana

Leishmaniose Visceral Canina

Leishmaniose Visceral

Leishmaniose Tegumentar Americana

Leishmania chagasi

Leishmania major

Leishmania evans

Leishmania donovani

Leishmania amazonenses

Leishmania braziliensis

Leishmania braziliensis

Leishmania. Leishmania chagasi

Leishmania. Leishmania infantum

Lutzomyia longipalpis

Lutzomyia forratini

Lutzomyia almerioi

Lutzomyia ayrozai

Lutzomyia neivai

Lutzomyia fischeri

do inglês, Latex Agglunation Test

do inglês, loop-mediated isothermal amplification

lipofosfogligano

do inglês, Nucleic Acid Sequence-Based Assay

Organização Mundial de Saúde

do inglês, Word Health Organization

Organizações não governamentais

Reação em Cadeia de Polimerase 
PAMPs

PPRs

MCP1

SFM

SUS

SINAN

MIP-1及

NTD

NO

RFC

RV1/RV2

RIFI

PPRs

rK 39

Th1/Th2

TGFß

TAC

IT-Leish

DAT

RFC

RAPD

UF

UB's

VL
Proteínas Moleculares associadas ao patógeno

Receptores de reconhecimento de patógenos

Proteína quimiotática de monócito 1

Sistema Fagocitário Mononuclear

Sistema Único de Saúde

Sistema Nacional de Agravos de Notificação

Proteínas inflamatórias de macrófagos- $1 \beta$

do inglês, Negleted Tropical

Óxido Nítrico

Teste de fixação de complemento

Iniciadores RV1 e RV2 (segmentos de ácidos nucleícos).

Reação de Imunofluorescência indireta

Receptores de reconhecimento

Proteína recombinante 39

Linfócitos T auxiliares

Fator de crescimento e transformação $\beta$

Termo de Ajustamento de conduta

Teste imunocromatográfico rápido

Teste de Aglutinação Direta

Teste fixação de complemento

Polimorfismo de DNA amplificado ao acaso

Unidade Federada

Unidades Básicas de Saúde

do inglês, Visceral Leishmaniasis 


\section{SUMÁRIO}

1 INTRODUÇÃO

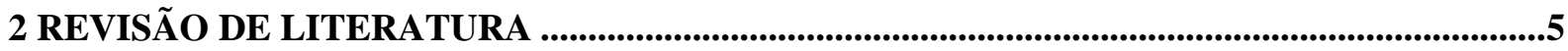

2.1 LEISHMANIOSE VISCERAL: ASPECTOS GERAIS ……………................................... 5

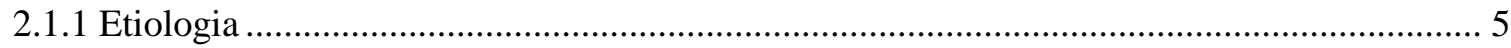

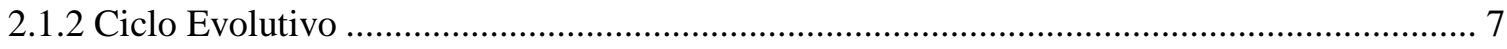

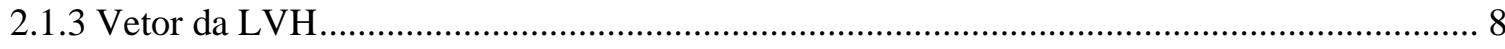

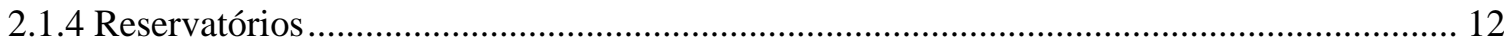

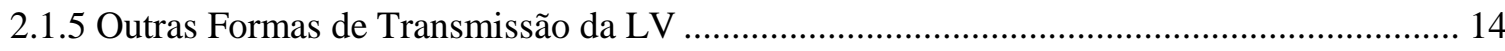

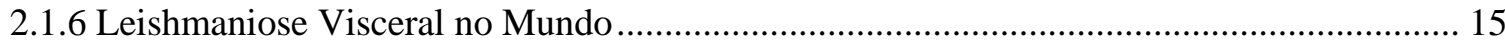

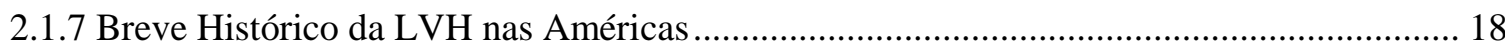

2.1.8 Evolução Histórica e Epidemiológica da LV ......................................................................... 19

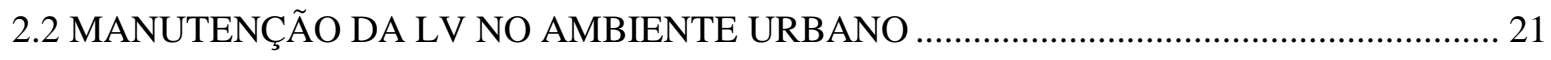

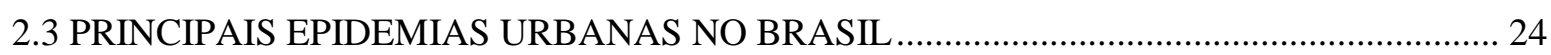

2.3.1 Características Epidemiológicas da LVH no Distrito Federal ...................................... 28

2.4 ASPECTOS GERAIS DA RESPOSTA IMUNOLÓGICA CONTRA LEIHSMANIA .............. 28

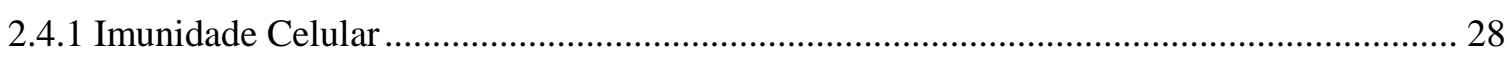

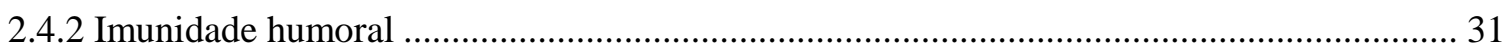

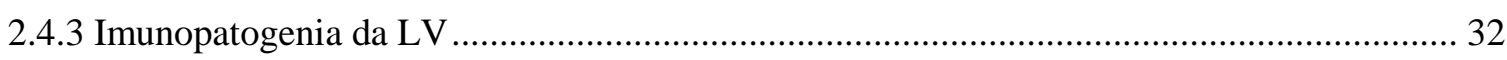

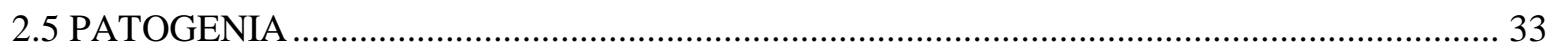

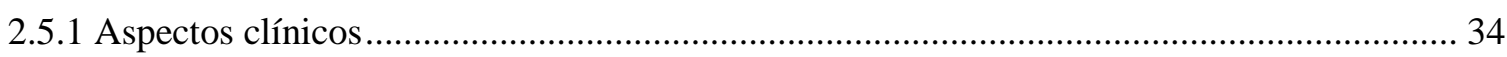

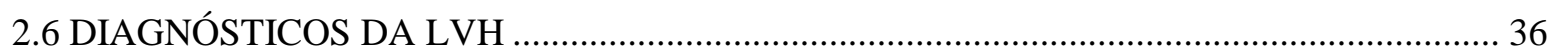

2.6.1 Teste Intradérmico de Montenegro (IDRM) e Suas Aplicações ........................................... 37

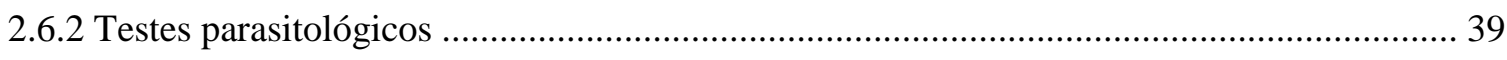

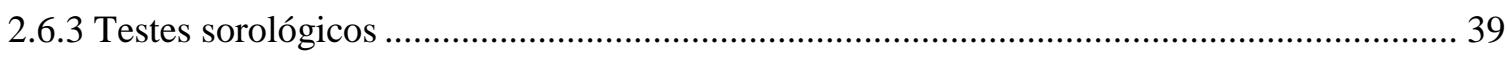

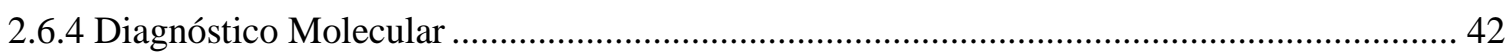

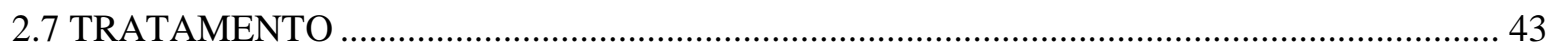

2.8 AS ESTRATÉGIAS DE CONTROLE DA LV E AS POLÍTICAS DE SAÚDE......................... 46

2.9 A LV NO ÂMBITO DA ATENÇÃO PRIMÁRIA À SAUDE................................................ 48

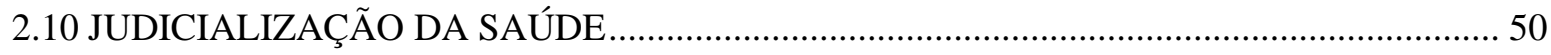

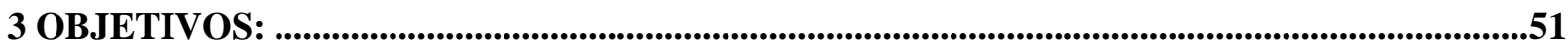

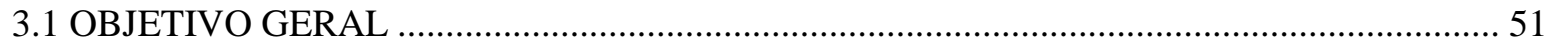

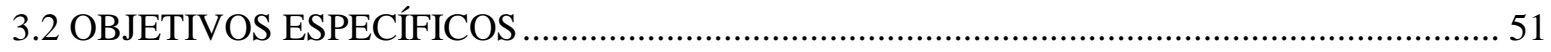

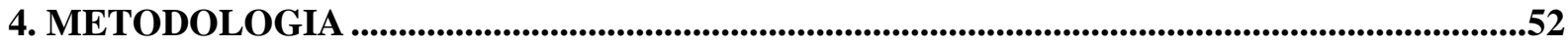

4.1 ESTUDO 1: JUDICIALIZAÇÃO DAS AÇÕES DE VIGILÂNCIA EM SAÚDE: O CASO DA

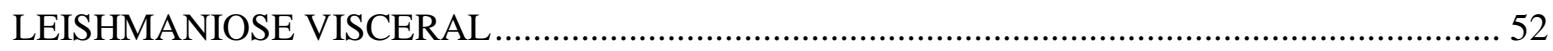




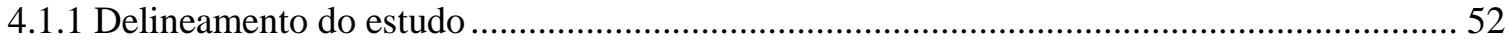

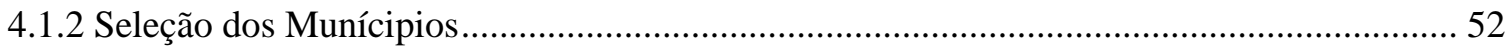

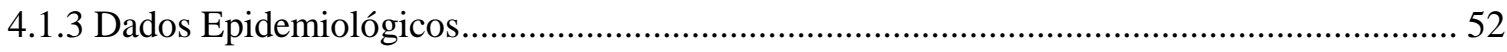

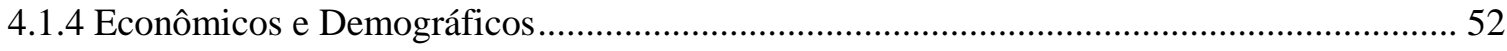

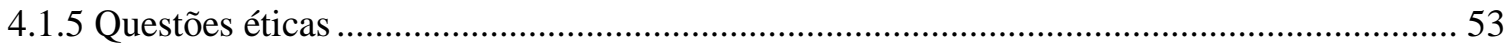

4.2 ESTUDO 2: A INSERÇÃO DA LEISHMANIOSE VISCERAL HUMANA NO ÂMBITO DA

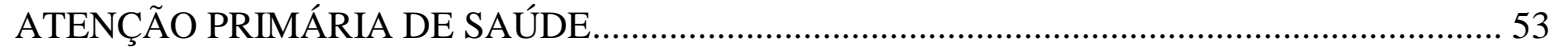

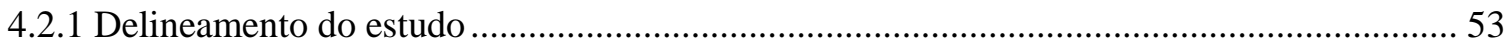

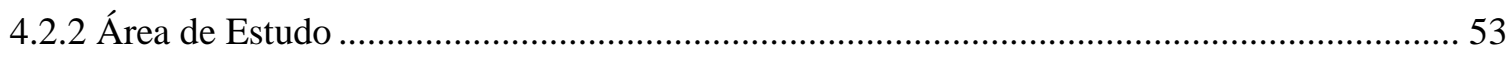

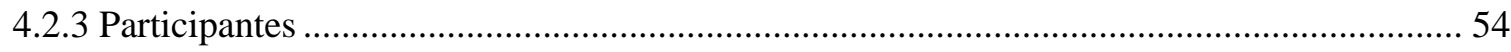

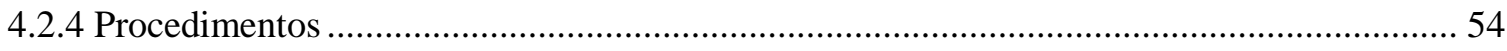

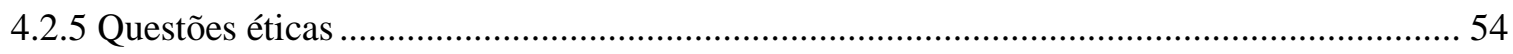

4.3 ESTUDO 3: EVOLUÇÃO DE CASOS ASSINTOMÁTICOS EM UMA ÁREA ENDÊMICA

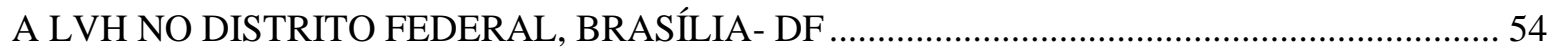

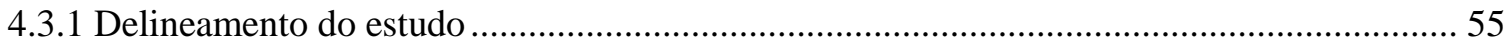

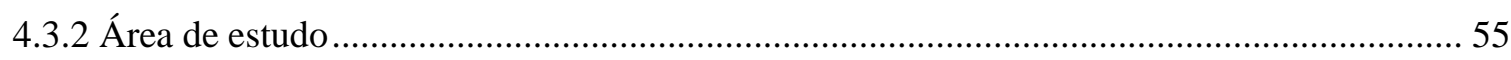

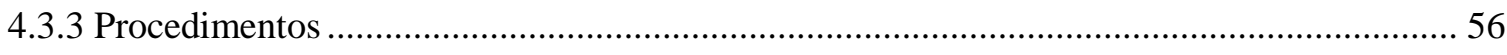

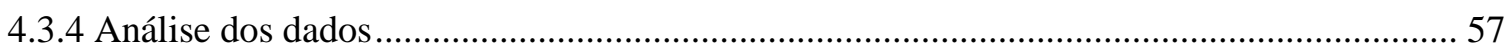

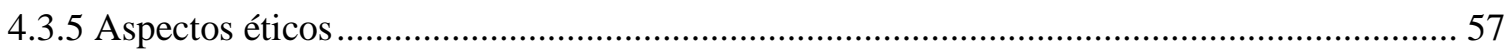

4.4 ESTUDO 4: Visceral Leishmaniasis epidemiologic evolution in timeframes based on demographic changes and scientific achievements in Brazil........................................................... 57

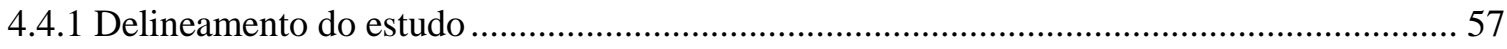

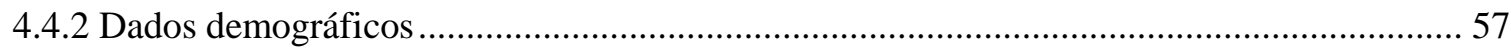

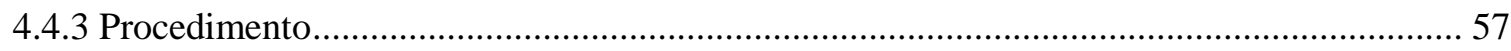

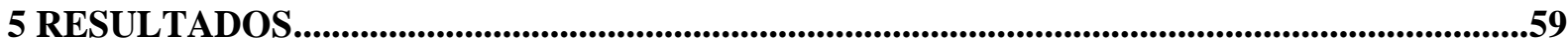

ARTIGO 1: Judicialização das Ações de Vigilância em Saúde: o caso da Leishmaniose Visceral . 77 ARTIGO 2: A inserção da atenção primária à saúde nos casos de Leishmaniose Visceral Humana . 86

ARTIGO 3: Evolução de casos assintomáticos de Leishmaniose visceral Humana em uma área endêmica do Distrito Federal-DF.

ARTIGO 4: Visceral Leishmaniasis epidemiologic evolution in timeframes based on demographic

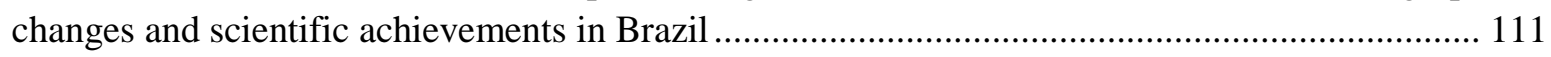

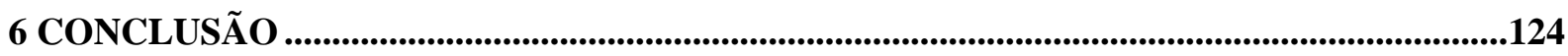

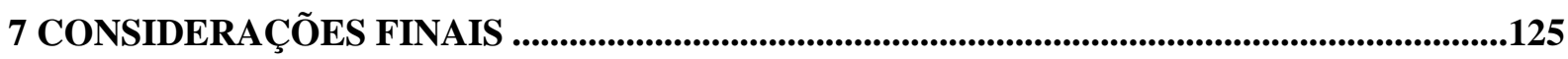

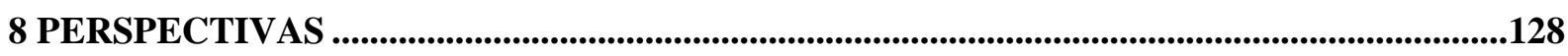

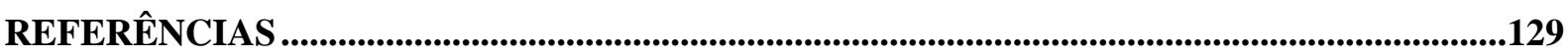

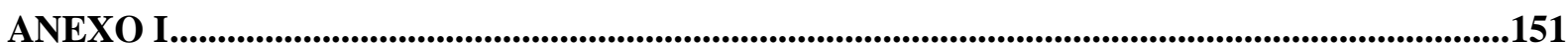




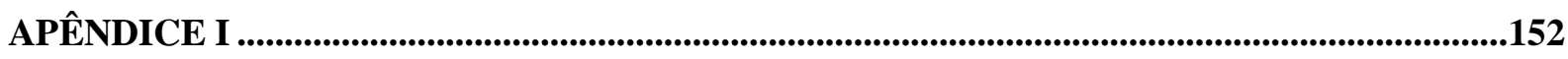

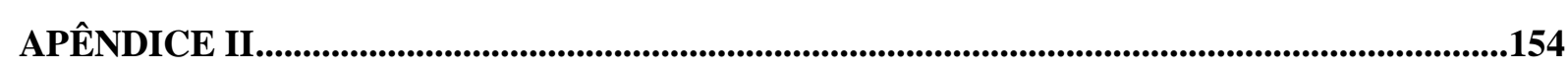

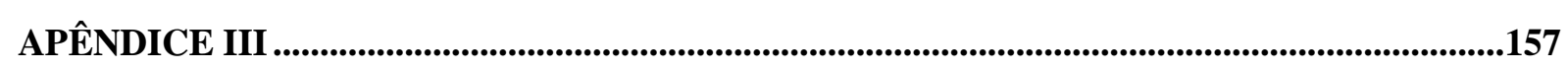

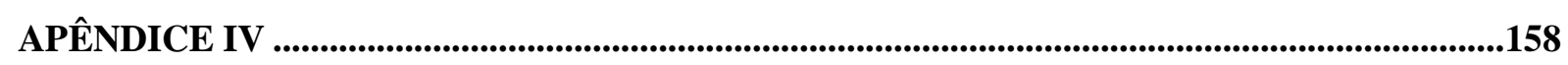




\section{INTRODUÇÃO}

A Leishmaniose Visceral Humana (LVH), ou Kala-azar, é uma zoonose de caráter sistêmico, caracterizada por evolução clínica crônica e potencialmente fatal ao homem quando não tratada. Seus agentes etiológicos são espécies do gênero Leishmania sp., pertencentes ao complexo L. donovani. Espécies deste complexo causam a LVH na África ( $L$. d. donovani) e Índia e a espécie L. infantum na Europa, norte da África e América Latina. ${ }^{1,2}$

A transmissão da doença se dá por meio da picada de insetos flebotomíneos, sendo o Lutzomia longipalpis a principal espécie envolvida no Brasil. O protozoário circula em dois ciclos distintos, mas intercomunicáveis. No ciclo urbano, o cão doméstico (Canis familiares) é o reservatório mais importante e no ciclo silvestre as espécies de raposas (Cerdocyon thous e Lycalopex vetulus) e os marsupiais (Dipelphis albiventris), são considerados reservatórios naturais da doença. Outras formas de transmissão foram descritas, tais como congênita, por meio do uso de drogas injetáveis e transfusão de sangue. ${ }^{3-5}$

Segundo a Organização Mundial de Saúde (OMS), a LVH é considerada uma das doenças parasitárias de maior impacto para a saúde pública mundial, com cerca de 500.000 casos estimados anualmente e 310 milhões de pessoas em risco de adquirir a doença no Mundo. Dados acerca da letalidade da doença são imprecisos, estimando-se que seja de cerca de $10 \%$, portanto, o número de mortes anualmente pode alcançar até 50.000 pessoas. ${ }^{6}$ É endêmica em 98 países e cerca de 90\% dos casos se concentram em Bangladesh, Nepal, Sudão, Índia e Brasil. ${ }^{7-9}$

A doença afeta principalmente populações que vivem em situação de pobreza e além de estar a ela ligada, também promove a sua perpetuação, aplicando-se a ela, portanto, o termo de doença negligenciada. Além deste fato, a dificuldade de acesso ao diagnóstico precoce, tratamento adequado e a efetividade das medidas de controle, caracterizam a LVH como uma das principais doenças negligenciadas do mundo. ${ }^{10-12}$

Em áreas endêmicas, o aumento do risco da infecção é ampliado pelas más condições de habitação, saneamento ambiental e processos migratórios. De acordo com a $\mathrm{OMS}^{6}$ além desses elementos, a subnutrição, com dietas pobres em Ferro, Vitamina A e Zinco, comprometem a resposta imunológica dos indivíduos, aumentando o risco da infecção evoluir para a doença. ${ }^{13-14}$

A OMS preconiza o fortalecimento das ações de vigilância e controle, com o objetivo de reduzir as formas graves da $\mathrm{LVH}$, por meio do acesso ao diagnóstico precoce, 
tratamento adequado dos casos e redução do contato-homem-vetor. Além da organização dos serviços e capacitação técnica dos profissionais, nas áreas de diagnóstico e tratamento. ${ }^{15}$

A LVH foi detectada pela primeira vez no Brasil no início da década de 1930, a partir da positividade de exames histopatológicos de material de viscerotomias oriundas de pacientes com suspeita de óbito por Febre Amarela das Regiões Sudeste, Norte Nordeste. ${ }^{16}$

A doença já havia sido detectada duas décadas antes no Paraguai em um doente que adquiriu a doença no Brasil. Com a descoberta do parasito no Brasil, houve a iniciativa do Instituto Oswaldo Cruz em enviar uma missão Chefiada por Evandro Chagas para investigação dos casos em estados onde havia se detectado casos. Até a década de 50 pouca importância foi dada para LV em decorrência das conclusões divulgadas pela dita comissão, que deu conta que a doença tinha caráter silvestre e, portanto, restrito às áreas rurais. ${ }^{4,17}$

Somente com o trabalho de Deane e Deane, ${ }^{18}$ em meados da década de 50, a doença foi diagnosticada no Estado do Ceará, no Munícipio de Sobral-CE. O aparecimento de um surto alertou as autoridades de saúde acerca da doença. Tal ocorrência impulsionou Evandro Chagas e a sua equipe a outras investigações epidemiológicas pelo Ceará e também por outros estados nordestinos. A partir daí, casos novos foram detectados principalmente na Região do Nordeste, sendo atualmente endêmica em quatro das cinco regiões do País. São reportados casos de LV em São Luís (Maranhão), Teresina (Piauí), Natal (Rio Grande do Norte), Aracajú (Sergipe), Fortaleza (CE), Rio de Janeiro, Corumbá (Mato Grosso do Sul) e em Minas Gerais. Essa possiblidade de expansão, já tinha sido alertada por Deane, fato que só viria se tornar um problema de saúde pública 30 anos depois (1962).

Para Belivacqua \& Alves, ${ }^{19}$ em algumas regiões brasileiras, a LV é apontada como reemergente, o que reforça as mudanças no padrão epidemiológico da doença a partir da década de $80 .{ }^{4,20-21}$

Atualmente, o número de casos de LV encontra-se em plena expansão com o aumento do número de casos nas últimas três décadas. Este aumento é associado a uma mudança da epidemiologia da doença, reconhecido na literatura como urbanização da LV. Isso decorre do fato que a maioria dos casos vem ocorrendo nas grandes cidades, uma vez que anteriormente era considerada uma endemia tipicamente rural. ${ }^{21-23}$

No intuito de elucidar o processo que concebeu a urbanização da LV, foram considerados os grandes movimentos migratórios ocorridos no Brasil em decorrência dos fatos políticos ou econômicos como relevantes para o entendimento da mudança epidemiológica da LV. ${ }^{24-25}$ 
Clinicamente a doença se caracteriza por um quadro febril arrastado com hepatoesplenomegalia e hipoplasia medular. $O$ paciente evolui com caquexia e imunodepressão, o óbito geralmente ocorre por infecções bacterianas secundárias caso não seja instituído o tratamento específico. ${ }^{26-29} \mathrm{O}$ diagnóstico se baseia em exames indiretos, principalmente sorológicos (ELISA, Imunofluorescência) e diretos como cultivo de espécimes biológicos, métodos moleculares (PCR) e análise histopatológica de órgãos como baço, fígado, medula óssea e linfonodos. Estes últimos são considerados métodos de referência para a confirmação diagnóstica de LV. Apesar de fornecer a certeza da infecção, por possibilitarem a visualização dos parasitos, esses testes pressupõem procedimentos invasivos e não apresentam uma sensibilidade ideal. ${ }^{30-31}$

O teste de hipersensibilidade tardia, intradermoreação de Montenegro (IDRM), é comumente usado para detectar uma resposta mediada por células. $\mathrm{Na}$ fase ativa da doença, o IDRM é negativo e após semanas da infecção ou após o tratamento, torna-se positiva. Na literatura, o IDRM é apontado como um teste útil no diagnóstico da forma assintomática ou inaparente da doença em áreas endêmicas. ${ }^{32-33}$

Os fármacos recomendados para o tratamento da LV são os antimoniais pentavalentes que são extremamente tóxicos para os seres humanos. ${ }^{34-35}$ A anfotericina B e a Milfetosina surgem como opções terapêuticas menos tóxicas e como opção ao fenômeno de resistência aos antimoniatos. Contudo, ainda não há um tratamento considerado como adequado para a LV, sendo esta uma questão importante nas falhas observadas no controle da doença, principalmente nas regiões em que o homem é o principal reservatório. ${ }^{35-36}$

As estratégias de controle recomendadas pelo Programa Nacional de Controle da LV são direcionadas nos seguintes eixos de atuação: a detecção precoce e tratamento de casos humanos, investigação sorológica de cães domésticos, controle vetorial e também programas de educação em saúde. Considerando que a doença ainda apresenta uma situação epidemiológica preocupante marcada por uma alta letalidade, muitos autores discutem a eficácia dessas medidas, principalmente no tocante à política de eliminação de animais infectados e doentes. ${ }^{13,37-38}$

O Ministério da Saúde incluiu a LVH como prioritária no programa de doenças negligenciadas. Sugere-se, portanto, que para o controle efetivo da doença é necessário investimento público no tratamento e no controle, contribuindo, com isso, para diminuição na incidência da doença e por consequência, na melhoria das condições de vida dos indivíduos e comunidades afetadas. ${ }^{8,11,39-40}$ 
A importância da LV no Brasil se deve à sua expansão territorial e a sua capacidade de gerar epidemias, podendo assumir formas graves e letais principalmente quando acomete populações mais pobres. As medidas de controle propostas pelo programa nacional se mostraram insuficientes para evitar o alastramento da doença pelo território, adicionando-se a isso a gravidade do quadro e as dificuldades terapêuticas.

A falência das medidas de controle, associada à expansão da doença, tornam necessários esforços por parte da comunidade científica em explicar e entender este novo fenômeno e consequentemente propor novas medidas de controle e avaliar as estratégias que estão sendo postas em prática pela saúde pública. Dado o aspecto multifatorial e a complexidade destas relações com os aspectos clínicos e parasitológicos da doença, este estudo se propôs a realizar algumas incursões analíticas nas áreas da vigilância em saúde, epidemiologia e da saúde pública, de forma a contribuir para esta discussão.

O primeiro estudo teve o objetivo de descrever a judicialização de um dos pilares do controle da LV no Brasil, considerando que vários munícipios afetados pela doença foram proibidos de executar as ações de controle do reservatório canino em decorrência da ação do Ministério Público provocado por organizações de proteção aos animais. No segundo estudo, foram realizadas entrevistas com profissionais de saúde da atenção primária à saúde de um território endêmico do Distrito Federal, com o objetivo de analisar outro pilar do programa de controle, o diagnóstico precoce e o tratamento da LVH. No terceiro estudo, realizou-se um estudo de série de casos entre os anos de 2011 a 2014, com a finalidade de descrever a evolução de indivíduos com IDRM positivo em um território endêmico de LV no Distrito Federal, com a proposta de acompanhar a progressão da doença e a dinâmica de transmissão no local. Por fim, no último estudo, foi realizada uma análise histórica da epidemiologia LV no Brasil, a fim de compreender o processo que consolidou a urbanização da doença, contribuindo dessa forma para a discussão de novas estratégias de abordagem da doença. 


\section{REVISÃO DE LITERATURA}

\subsection{LEISHMANIOSE VISCERAL: ASPECTOS GERAIS}

\subsubsection{Etiologia}

Os protozoários do gênero Leishmania (Ross, 1903) se referem à ordem Kinoplastida, membros da família Trypanosomatidae, e membros do complexo Leishmania donovani. São classificadas em quatro espécies: Leishmania archibaldi, L. chagasi, L. donovani e infantum. 1,2, $41^{-}$

Na literatura são descritas aproximadamente 30 espécies de Leishmanias, destas, 20 são consideradas patogênicas e causadoras de infecção em espécies de mamíferos e em humanos. ${ }^{2,41-43}$

A taxonomia das espécies de Leishmanias ainda é controversa. Em meados de 1987, a classificação deste parasito baseou-se em características biológicas do parasito em função do seu aparelho digestório, do perfil imunológico e bioquímico dos parasitos. ${ }^{44}$

As diversas espécies de Leishmanias são responsáveis pelas formas variadas de leishmanioses que infectam mundialmente milhares de pessoas. As características clínicas dependem da interação entre a resposta imune do hospedeiro vertebrado e da invasividade, tropismo e patogenicidade deste parasito. Desta forma, representam um complexo de doenças: leishmaniose cutânea, cutânea difusa, muco-cutânea e a visceral, caraterizada como fatal quando não tratada adequadamente. ${ }^{8,41,43,45}$

As espécies reconhecidas como causadoras da LV se distribuem de acordo com a área geográfica. A L. infantum (sny L. chagasi) no Novo Mundo e na área do Mediterrâneo. E a L. donovani, no Oriente, África Central e Oriental e Índia. ${ }^{12,23,41,46}$

De um modo geral, as leishmanioses se apresentam como uma zoonose, doença primariamente de animais que afetam o homem, mas que também podem se comportar como antropozoonoses, quando é transmitida do animal para o homem. ${ }^{4,8,33}$

A Leishmania chagasi é comumente encontrada no Novo Mundo. Na Colômbia e na Venezuela a espécie incriminada é a L. evansi. Além da L. chagasi, no Brasil, existem também a distribuição de outras espécies de L. amazonenses e L. brasizilienses identificadas como causadoras da leishmaniose cutânea. ${ }^{38}$ 
O agente etiológico da LV foi descrito pela primeira vez por Cunha \& Chagas, 1937, tendo recebido o nome específico de Leishmania chagasi, um parasito pertencente à família Tripassomatidae Doflein (1901) e ao gênero Leishmania (Ross, 1903). A decisão de considerá-lo como uma nova espécie de Leishmania deveu-se, principalmente, aos repetidos resultados negativos que se seguiram às tentativas de infecção experimental de cachorros com o parasito. A partir disso, foi possível diferenciá-lo de outro agente etiológico de leishmaniose da LV já conhecido em outros países europeus da bacia do Mediterrâneo, a L. infantum (Nicolle, 1908). ${ }^{47}$

Após cinquenta anos de descrição da $L$. chagasi, realizou-se uma profunda revisão do gênero, de acordo com a nova reclassifica a Leishmania como membro do subgênero, Leishmania (Saf'Janova, 1982 Ross, 1903), espécie L. chagasi. ${ }^{48}$

Essa espécie foi apresentada por Cunha et al. ${ }^{49}$ como a principal responsável pela LV nas Américas. Essa nomenclatura permaneceu em uso por muito tempo. Para Laison and Shaw $^{48}$, a razão para considerar a origem do parasito nas Américas, está associada principalmente a sua origem em animais selvagens nativos, especialmente raposas.

A partir das considerações feitas por Killick-Kendrick, ${ }^{50}$ prevaleceu a proposta que a L. infantum teria sido importada para América Latina durante a colonização europeia. Para Maurício ${ }^{1}$, a espécie chegou antes mesmo da separação do Continente Americano com a África. ${ }^{47,51}$

Um estudo comparativo entre cepas de L. chagasi, isoladas de diferentes origens e países da América do Sul, particularmente do Brasil, (de humanos, cães domésticos e da raposa selvagem Cerdocyon thous e também cepas de L. infantum originadas da área endêmica para leishmaniose visceral em países europeus da Bacia do Mediterrâneo, tais como Portugal e Espanha, foi possível concluir por meio de técnicas moleculares de RAPD e de RFLP que as sequências de DNA de ambos as espécies de parasitos eram idênticas. Para tanto, os autores propuseram a separação taxonômica dos dois parasitos. Contudo, Lainson et al. ${ }^{48}$ consideram a $L$. chagasi sinônimia de L. infantum e que ambas não deveriam ser consideradas espécies diferentes.

Para Lainson et $a l .{ }^{52}$, entretanto, a espécie deveria permanecer em nível subespecífico como Leishmania (L) infantum chagasi, haja vista suas características etiológicas, como o habitat silvestre de seu flebotomíneo vetor, Lutzomyia longipalpis, e seu reservatório natural, a raposa selvagem (Cerdocyon thous). Outra razão apresentada pelos autores refere-se às diferenças moleculares estabelecidas entre os perfis de fragmentos de 
kDNA de L. chagasi e L. infantum, demonstradas pelo uso de técnicas de digestão por endonuclease de restrição, análise da principal proteína de superfície (gp63) e de suas formas promastigotas, da geração de anticorpos monoclonais contra superfícies de promastigotas e de estudos comparativos de radiorrespirometria. ${ }^{53}$

Por fim, há várias suposições documentadas na literatura acerca do surgimento da $L$. chagasi e o possível agente etiológico da LVH nas Américas. Para alguns autores, o fato de existirem pequenas diferenças filogenéticas, enquadram a L. chagasi e L. (infantum) como sinônimas. ${ }^{48,54}$

Os estudos de diversidade genômica dos membros do complexo L. donovani realizadas por Maurício et al. ${ }^{1}$ permitiram concluir que não há motivos separação das duas espécies. Rangel ${ }^{55}$ e Laison \& Shaw ${ }^{4}$ aventam que a nomenclatura L. (infantum) chagasi é considerada em função da identidade molecular entre as duas espécies. ${ }^{53,56}$

De acordo com a literatura, a revisão das espécies pertencentes ao complexo $L$. donovani ainda permanece em debate, por essa razão, este trabalho considerou a $L$. chagasi como sinonímia de L.infantum. ${ }^{1,4,47,51}$

\subsubsection{Ciclo Evolutivo}

Os protozoários do gênero Leishmania caracterizam-se por serem organismos unicelulares com a presença de um flagelo e uma estrutura rica em DNA, o cinetoplasto. A sua multiplicação ocorre por fissão binária, tanto nos hospedeiros vertebrados quanto invertebrados. Apresentam um ciclo heteroxênico, alternando entre um hospedeiro mamífero e insetos vetores do gênero flebotomíneo (figura 1). ${ }^{23,43,45,57}$

O ciclo do parasito se desenvolve quando flebotomíneos fêmeas se infectam durante o repasto sanguíneo em reservatórios com a ingestão de macrófagos infectado por Leishmania. O inseto-vetor adquire as formas amastigotas que, dentro da membrana peritrófica, transformam-se em promastigotas, forma infectante e ,desta forma, se multiplicam no intestino médio do vetor. A partir de então, tornam-se promastigotas infectantes de 8 a 20 dias após invasão. No tubo digestivo do inseto-vetor, o ciclo dura em torno de 72 horas. ${ }^{41,43 \text {, }}$ 58

Esse evento ocorre após os promastigotas terem sofrido modificações bioquímicas em sua superfície, perdendo assim, sua capacidade de adesão ao epitélio do intestino médio do flebotomíneo. Durante um novo repasto sanguíneo em um hospedeiro humano ou em outro 
mamífero, as fêmeas inoculam a saliva contendo os parasitos, formas promastigotas, e, além disso, substâncias anticoagulante, vasoativa, com papel relevante na infectividade e imunossensibilização do hospedeiro. Esses parasitos serão fagocitadas pelas células do Sistema Fagocitário Mononuclear-SFM (macrófagos, neutrófilos e células dendríticas imaturas, células de kupffler do fígado, células reticulares, macrófagos do baço e medula óssea do hospedeiro vertebrado) transformando-se em amastigotas. Há uma reprodução por fissão binária e subsequentes multiplicações desses parasitos no interior das células infectadas ocasionam o rompimento celular com a liberação de amastigotas. $\mathrm{Na} \mathrm{LV}$, o parasito tem tropismo pelo sistema monofagocitário de tecidos linfoides, fígado, baço e medula óssea. ${ }^{58-60}$

Fonte: Harvay et al., 2011 (adaptado). ${ }^{23}$

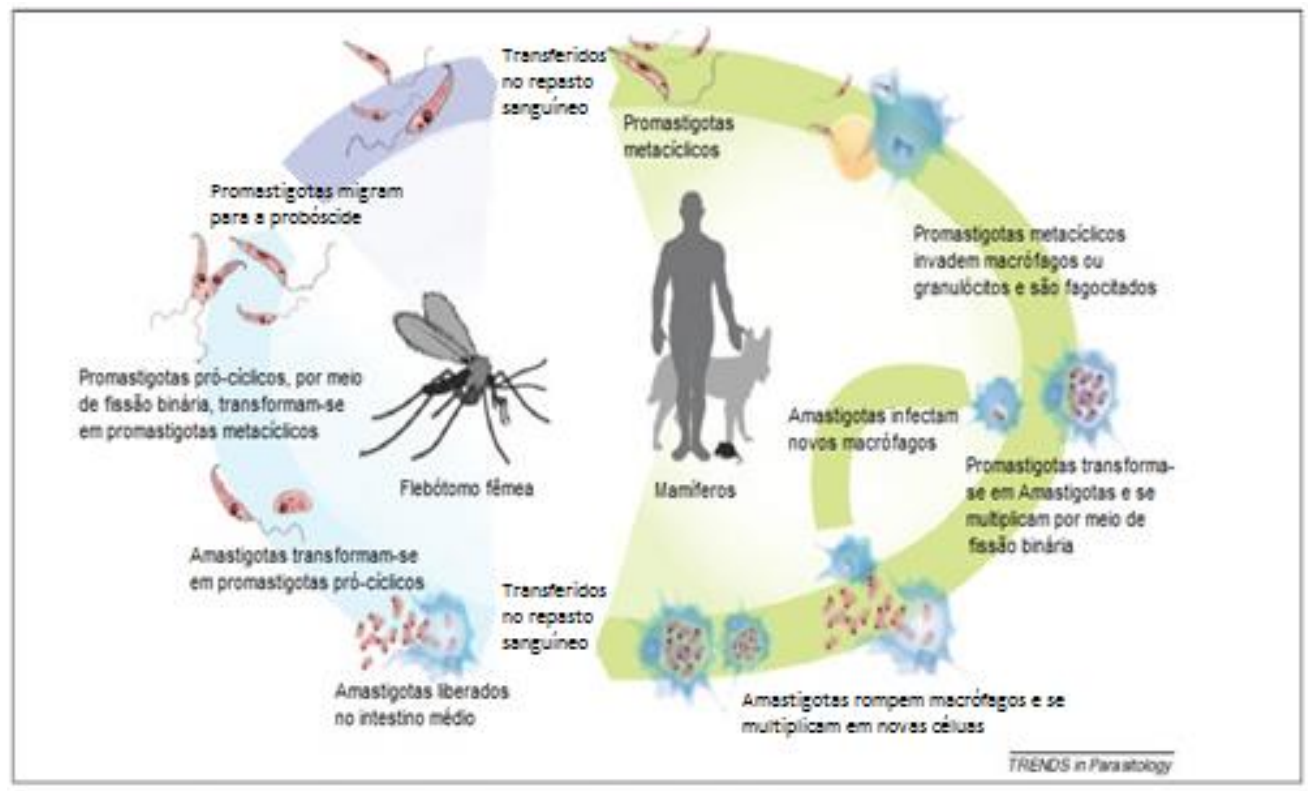

Figura 1. Ciclo biológico da L. infantum (syn. chagasi).

\subsubsection{Vetor da LVH}

Os vetores transmissores da LVH pertencem ao grupo dos flebótomos (Díptera: Psychodidae: Phlebotominae). Apresentam uma distribuição pantropical com algumas espécies encontradas nas regiões temperadas. Nas Américas, distribuem-se do extremo sul do Canadá até o norte da Argentina. Algumas espécies são de distribuição restrita, regional ou 
local, outras são de ampla distribuição continental, resultando em largas faixas de superposição. ${ }^{61-62}$

Caracterizam-se por serem insetos pequenos que medem aproximadamente de 1 a 3 mm com um corpo amarelado revestido de cerdas e são de coloração clara (castanho claro ou cor de palha). São facilmente reconhecíveis, tendo em vista o seu comportamento, ao voar em pequenos saltos e pousar com as asas abertas. Apresentam hábitos vespertinos e noturnos. Há indícios de que o período de maior transmissibilidade da doença ocorra, durante ou logo após o período de chuvas, quando há um aumento da densidade populacional de insetos (figura 2). 13

As fêmeas de flebotomíneos, a cada ovoposição, depositam entre quarenta e setenta ovos em solo. A eclosão ocorre após 6 a 17 dias, dando origem às larvas. Estas, por sua vez, evoluem no solo para o estado de pupa em 15 a 70 dias. Após uma a duas semanas dão origem aos adultos, que vivem de 15 a 30 dias. O ciclo completo, de ovo a adulto, dura em média 30 a 90 dias dependendo da temperatura, requerendo mais três dias para se tornar infectante. ${ }^{63}$

Fonte: Public Health Library

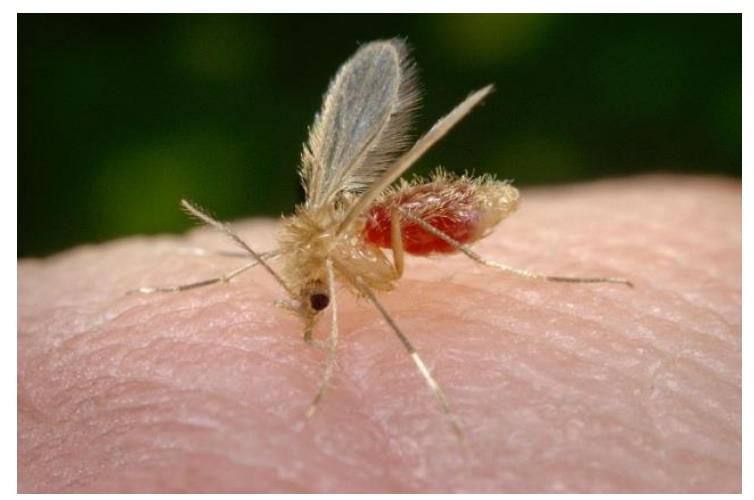

Figura 2. Fêmea de Flebotomíneo adulto, engurgitada.

$\mathrm{Na}$ fase adulta, esses insetos estão adaptados a diversos ambientes terrestres, de caráter úmido e rico em matéria orgânica necessitando de baixa incidência luminosa para o seu desenvolvimento. Ambos os sexos necessitam de carboidratos como fonte energética. Apenas as fêmeas são hematófagas, cujo hábito é importante para o desenvolvimento de seus ovos. $^{13}$

Mundialmente já foram identificadas 989 espécies de flebotomíneos distribuídas entre o Novo e Velho Mundo, dos quais 531 foram registrados nas Américas. ${ }^{64,65}$ 
De acordo com a área geográfica, as espécies se distribuem em Phlebotomus argentipes e Phlebotomus (Larrousius) perniciosus; Flebotomus (Larrousius) ariasi e neglectus (Velho Mundo), Sergentomyia (Novo e Velho Mundo). O Lutzomyia é o gênero responsável pela transmissão no Novo Mundo das leishmanioses e também de bartoneloses e arborviroses. $^{61,66-68}$

Há aproximadamente 70 espécies desse gênero consideradas importantes causadores de doenças humanas. O conhecimento da fauna flebotomínica é de grande importância, tendo em vista a sua versatilidade em transmitir diversos agentes patogênicos para homens e animais e porque seu controle é recomendado como medida para se evitar essas doenças ${ }^{61,69-}$ 70.

$\mathrm{Na}$ fauna brasileira de flebotomíneos são descritas aproximadamente 230 espécies. A Lutzomyia longipalpis, (Díptera: Psychodidae) reconhecida por Lutz \& Neiva, ${ }^{71}$ é o principal vetor responsável pela transmissão da Leishmania chagasi na América Latina, apresentando ampla distribuição pelo Brasil, estando envolvida em mais de $90 \%$ dos casos. ${ }^{72}$

Um levantamento entomológico registrou, em Pernambuco, a presença de 37 espécies de flebotomíneos desse gênero. De acordo com o estudo, a razão para a existência dessa espécie seria principalmente devido à sua adaptação às condições climáticas extremas na região. O levantamento ainda demonstra que essa diversidade de espécies é menor quando comparado com outros estados brasileiros como Alagoas, Ceará, Paraíba, Rio Grande do Norte e Sergipe, que apresentam densidade ainda maior dessas espécies. ${ }^{73-74}$

Esse flebotomineo pode ser encontrado em quase todas as regiões brasileiras, principalmente nas regiões Norte, Nordeste, Sudeste e Centro-Oeste. Típico de vegetação rasteira ou arbustiva, essa espécie é conhecida popularmente como mosquito palha, birigui ou tatuquiras. ${ }^{69-70,75}$

No Brasil, a presença da espécie $L u$. cruzi foi incriminada por Missawa et al. ${ }^{76}$ como vetora da L. infantum (syn. chagasi) no munícipio de Juciara, na região de Corumbá e Ladário, nas quais não havia registros do L. longipalpis. Segundo os autores, o Lu. cruzi foi encontrado naturalmente infectado por L.infantum (syn. chagasi). Pita-Pereira et $\mathrm{l}^{77}$ discutem que além do Lu. longipalpis, em Corumbá, há predominância do Lu. forattinni contribuindo para a transmissão da doença. A presença desta espécie e a alta incidência de casos humanos na região sugerem que ela participaria na cadeia de transmissão. ${ }^{76 ; 78-79}$ 
Outros estudos realizados em diversas áreas do território brasileiro revelam também a possibilidade da transmissão da LV por outras espécies vetoras: Lu. forratini, Lu. almerioi, Nyssomyia neivai, Nyssomyia antunesi, Migonemyia migonei e Nyssomyia neivai. ${ }^{80,81}$

Embora a Região Sul do país não apresente uma incidência significativa de casos da LVH, Marcondes et al. ${ }^{82}$ apresentam um estudo da fauna de flebotomíneos na parte leste de Santa Catarina, no município de Pirraças. Neste levantamento, foram identificados três espécies de Lutzomyia: Lu. ayrozai, Lu. neivai; Lu. fischeri, transmissores da leishmaniose tegumentar na região.

De acordo com o MS (2014), ${ }^{13} L u$. longipalpis e Lu. cruzi são as principais espécies transmissoras da LVH no Brasil, sendo a primeira a mais importante. Marcondes \& Rossi ${ }^{7}$ discutem que além da alta capacidade adaptativa desses vetores ao ambiente, outros fatores contribuem significativamente para a dispersão geográfica dessas espécies, dentre eles destacam-se as mudanças na ecologia do vetor oriunda do fenômeno de urbanização da doença. ${ }^{61-62,64}$

Almeida et al., apresentam um estudo acerca dos aspectos epidemiológicos e ecológicos dos flebotomíneos na região Centro Oeste do Brasil. De acordo com ao autores, as espécies de flebotomíneos estão localizadas no Mato Grosso-MT (106 spp), MS (57 spp), GO (41 spp) e DF (27 spp). ${ }^{64,83}$ Contudo, apenas 20 espécies estão envolvidas com a transmissão da Leishmania no Brasil. De acordo com o estudo, o Lu. longipalpis é encontrado em todos os biomas da região Centro-Oeste, confirmando a adaptabilidade desses flebotomíneos a diferentes ambientes (figura 3).

De um modo geral, os flebotomíneos se adaptam preferencialmente ao ambiente peridomiciliar alimentando-se de uma grande variedade de hospedeiros vertebrados, entre aves, homem e outros animais silvestres e domésticos. Uma das razões para essa adaptação reside na proximidade do homem às áreas de floresta remanescente e a criação de animais domésticos que permitem a atração de flebotomíneos ao peridomicilio. Esta condição poderia ser indicada como um determinante para o aumento no número de casos da LVH nas áreas urbanas. $^{84-86}$ 

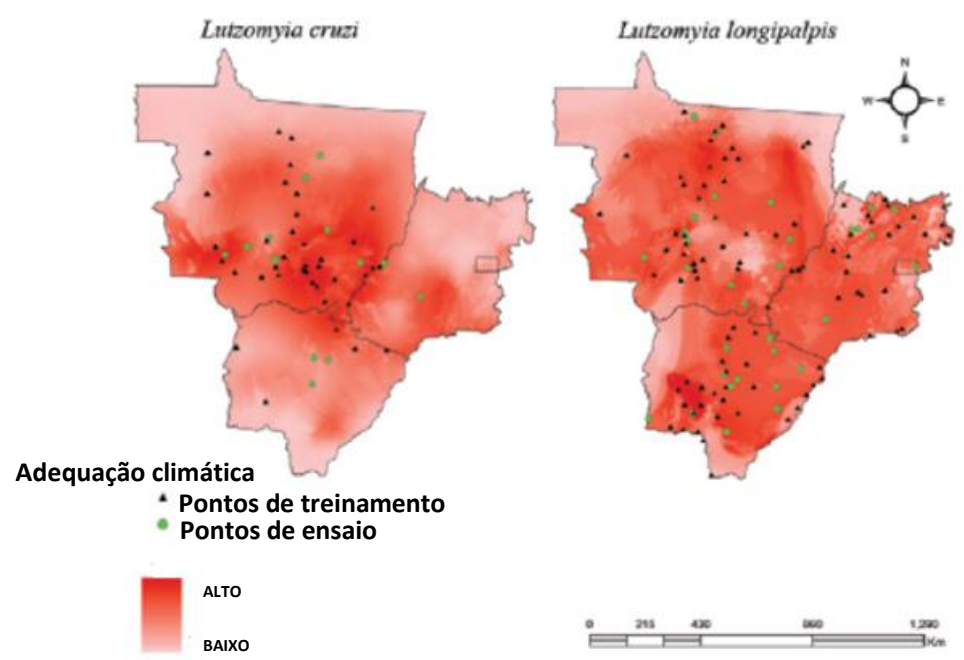

Figura 3. Distribuição dos vetores da Leishmaniose Visceral na região Centro-Oeste do Brasil

\subsubsection{Reservatórios}

As raposas da espécie Cerdocyon thous e gambás Dipelphis albiventris são encontrados naturalmente infectados na natureza e atuam como os principais reservatórios da LV no ambiente silvestre. ${ }^{12} 87$ A raposa do gênero Dusicyon vetulus foi o primeiro canídeo silvestre no continente americano implicado como reservatório da leishmaniose sendo descrita a infecção por Leônidas e Maria Deane na década de $1950{ }^{88}$

No estado da Bahia, em 1984, foram registrados gambás Dipelphis albiventris, naturalmente infectados. ${ }^{89}$ Este foi o primeiro registro no Novo Mundo de um reservatório silvestre marsupial por L. chagasi. Essa infecção pode também ser identificada em outros gêneros de marsupias, como Cerdocyn Thous, no estado do Pará. No Ceará, isolou-se a $L$. chagasi em algumas espécies de raposas Lycalopex vetulus.

O cão doméstico (Canis familiaris) é o principal reservatório da LV na área urbana, e atua como um elo na transmissão da doença. ${ }^{13,90}$ A enzootia canina tem sido relatada como precursora dos casos humanos. Apesar disso, em algumas áreas, ele não é visto como fonte preferencial de alimentação para o L. longipalpis. Um estudo realizado em uma área de transmissão de LV demonstrou-se que 38,8\% dos flebotomíneos se alimentavam de aves, 21,2 de roedores, 13,5 de sangue humano e em menor proporção, em amostras sanguíneas, de gambás, bois e cavalos. ${ }^{85}$ Essa preferência do vetor também foi comprovada através do 
repasto sanguíneo em ovelhas, e cabras. Contudo, esses animais atuariam como reservatórios da doença. ${ }^{93}$

Outros resultados semelhantes foram observados com flebotomíneos capturados em municípios de três estados da Região Nordeste do Brasil, onde se verificou que os vetores se alimentaram preferencialmente de sangue de aves e, em segundo lugar, de cães. Também foi comprovada a ocorrência de repasto sanguíneo. ${ }^{93}$

Eventualmente a LV pode acometer gatos Felis catus sendo estes mais susceptíveis a leishmaniose tegumentar. A descoberta da leishmaniose em felinos ocorreu em 1912, na Algéria, quando foram encontrados em um ambiente doméstico um gato e uma criança infectada por L.infantum, ambos portadores de LV. O diagnóstico baseou-se no achado de formas amastigotas do parasito em medula óssea, sem a identificação da espécie causadora de enfermidade. Após o registro do primeiro caso clínico, a literatura mundial registra a positividade por Leishmania nos felideos em países, como Estados Unidos, Espanha, Itália, Portugal e Brasil. ${ }^{94-96 .}$

Nas Américas, o primeiro caso de leishmaniose visceral em gatos, ocorreu em 2001, no Estado de São Paulo. ${ }^{97}$ Algumas pesquisas em áreas endêmicas demonstraram que essa espécie de animal é capaz de se infectar e desenvolver os sintomas da doença. ${ }^{98-99}$

O papel dos felinos no ciclo de transmissão ainda é controverso. Há uma escassez de trabalhos que discutem o papel biológico desses animais em locais onde há a presença de flebotomíneos. Para alguns autores, esses animais atuariam como reservatórios secundários da doença. Em xenodiagnósticos, foi comprovado que os gatos infectados por L. infantum foram capazes de infectar o vetor. ${ }^{7}$

Acredita-se que haja uma determinada resistência natural de felídeos domésticos a infecções por Leishmania spp. De acordo com os alguns autores, isso se deve provavelmente a determinados fatores genéticos. ${ }^{100-101}$

Por fim, autores aventam a necessidade de se desenvolver pesquisas que discutam o envolvimento de felídeos e com isso definir o seu papel na dinâmica de transmissão da parasitose. A grande suscetibilidade desse animal a certas doenças tornou-se de grande importância o estabelecimento de um ciclo doméstico de infecção como a Leishmaniose. ${ }^{102-}$ 103

O papel das aves no ciclo de transmissão da LV também é controverso. Em Pernambuco, comprovou-se que as criações de aves ao redor de moradias poderiam atuar como uma barreira profilática para infecção por L. infantum, diminuindo a população de 
flebotomíneos no interior das residências e elevando a quantidade nos galinheiros. Porém, estudos apontam que a presença de galinhas nas residências está relacionada a uma maior proliferação do vetor da LV. Por fim, acrescentam ainda que a presença de patos, roedores e pássaros aumenta o risco de ocorrência da doença na área urbana. ${ }^{104}$

Fonte: (MS, 2014) $)^{13}$

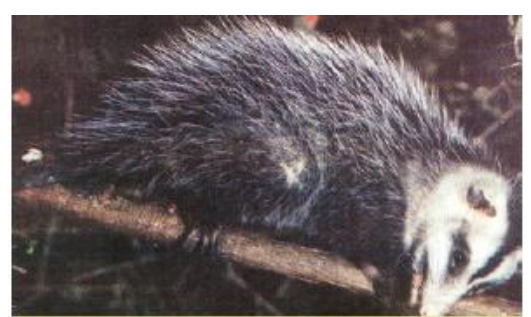

Gambás: Dipelphis albiventris

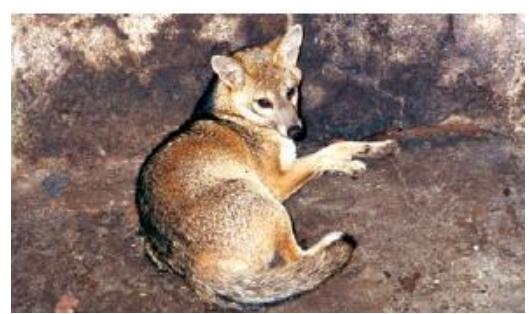

Raposa silvestre: Cerdocyon thous

Figura 4. Reservatórios silvestres da L. chagasi.

\subsubsection{Outras Formas de Transmissão da LV}

A forma de transmissão predominante da LV é a vetorial. Contudo, há outras formas de transmissão, como por exemplo, a transfusão de sangue, acidentes de laboratório e compartilhamento de seringas contaminadas no uso de drogas injetaveis, sendo esta, a mais frequente em pacientes infectados com HIV., 7, 105

Em um caso clínico, foi revelada a LV em um paciente pós-transplante renal, com resultados negativos contra a Leishmania, mas que evoluiu para o óbito. Contudo, os autores sugerem a pesquisa de LV em doadores e preceptores de órgãos provenientes de áreas endêmicas. ${ }^{106}$

O primeiro caso documentado de LV em gestantes ocorreu na Índia, com a passagem de amastigotas pela barreira transplancentária, como relatam Low e Cooke. ${ }^{107}$ Esses autores discutem a dificuldade de diagnostico na paciente e no recém-nascido, embora na época a doença tenha sido identificada em amostra esplênica da gestante. Em 1955, há o relato na Inglaterra de uma gestante que residiu na Índia, onde a criança manifestou aspectos clínicos da doença e confirmação laboratorial no sétimo mês de vida. ${ }^{108-109}$

Em 1999, Meinecke et al. ${ }^{110}$ demonstram a ocorrência de oitos casos de LV congênita no Mediterrâneo. Em todos esses casos a mãe apresentara sintomas da doença. Contudo, relatou-se o caso da doença transmitida por uma mãe assintomática que residiu em uma área endêmica de LVH e com sorologia e teste Montenegro positivo. 
Durante uma epidemia de LV no Sudão, Eltoum et al., ${ }^{111}$ relatam casos de LVH congênita, no qual foram registrados dois casos. No primeiro caso, a criança apresentou febre, linfoadenopatia e hepatoesplenomegalia com os parasitos detectados na medula óssea. E no segundo, foram encontrados parasitos na placenta de um feto de cinco meses de idade.

Para Paglinano et al., ${ }^{112}$ as mudanças fisiológicas que ocorrem na gestação com consequente diminuição da resposta imune celular e aumento da imunidade adquirida (predominância de uma resposta Th1) aumentam o risco da gestante em adquirir determinadas infecções parasitárias, tal como a LV.

$\mathrm{Na}$ América do Sul, a LVH na gestação é considerada rara, haja vista à escassez de trabalhos que relatam esses casos. Em relação ao Brasil, o primeiro caso foi relatado, em 1993, com ocorrência registrada em áreas urbanas e periurbanas. Sequencialmente, outros casos foram relatados.

Ao analisar casos de LV em crianças de 0 a 8 meses, Maciel et al. ${ }^{14}$ concluíram que os casos de LV em mães assintomáticas também devem ser considerado, pois nessas condições, condicionam o desenvolvimento de LV em crianças em áreas indenes. Para os autores, esse tipo de transmissão vertical desempenha um papel relevante na disseminação e manutenção da LV em áreas endêmicas do Brasil.

Para a LVC, alguns autores admitem a possibilidade de transmissão canina através da ingestão de carrapatos infectados e mesmo através de mordeduras, cópula, ingestão de vísceras contaminadas, porém não existem evidências científicas acerca da importância epidemiológica destes mecanismos para humanos ou na manutenção da enzootia ${ }^{13,113-114}$.

\subsubsection{Leishmaniose Visceral no Mundo}

A LV tem ampla distribuição geográfica ocorrendo principalmente na Ásia, Europa, no Oriente Médio, na África e nas Américas. Os casos da doença abrangem 98 países localizados ems regiões tropicais e subtropicais ${ }^{6,41,115-116}$

Estima-se que 200.000 a 400.000 novos casos de LV ocorram no mundo a cada ano. Mais de $90 \%$ dos casos globais são notificados em regiões pobres da Índia, Blangladesh, Nepal, Sudão, Etiópia e Brasil. Além destes, há casos reportados também no Afeganistão, Algéria, Iran, Peru, Árabia Saudita e Síria. ${ }^{6,8,13,116-118}$ 
A LVH também foi descrita no Paraguai, Argentina, Colômbia, México até o Norte da Argentina, atingindo ainda a Guatemala, Honduras, Nicarágua, Colômbia e Venezuela. 6, 38, 116

Segundo a OMS, a LV é considerada uma das doenças parasitárias de maior impacto para a saúde pública mundial. Estima-se a ocorrência global de 58.000 casos anuais de LVH e cerca de 350 milhões de pessoas expostas em áreas de risco de transmissão. ${ }^{119}$

Em 2010, havia um total de 200 milhões de pessoas em risco para aquisição da doença, sendo registrados cerca de 300.000 casos novos e mais de 20.000 mortes anuais no Mundo. Os grupos mais acometidos são crianças desnutridas, imunodeprimidos e indivíduos infectados com HIV. A letalidade por LV pode alcançar 90\% em indivíduos não diagnosticados e/ou tratados inadequadamente. ${ }^{6,13,120-121 .}$

A suscetibilidade a LVH é universal, atingindo pessoas de todas as idades e sexo. ${ }^{13,}$ 122 Entretanto, a maioria dos estudos na literatura aponta o sexo masculino como o mais sucetível à doença. Ao descrever casos de LVH em Campo Grande, Botelho \& Natal ${ }^{123}$ demonstraram que dos 44 óbitos notificados, 33 (75\%) pertenciam ao grupo masculino e uma letalidade de $15 \%$ em homens dos 20 aos 49 anos. Além disso, apresentavam um risco maior de adoecimento.

$\mathrm{Na}$ literatura, essa frequência de casos de LV no sexo masculino ainda não está totalmente esclarecida. A distribuição da doença entre os sexos é semelhante durante a infância, mas predomina em homens a partir da adolescência. Sugere-se, contudo, um fator hormonal ligado ao sexo ou à exposição. Estudos em animais sugerem que hormônios sexuais como a testosterona ${ }^{124}$ ou estrôgenos ${ }^{125}$ alteram a susceptibidade à infecção por parasitos intracelulares. Além disso, hábitos de vida relacionados à maior permanência fora dos homens fora do domícilio, com maior superfície corporal exposta, aumentam a vulnerabilidade à infecção. ${ }^{21,126-127}$

Esse perfil epidemiológico também é registrado entre co- infectados, passando de 25 no ano de 2001 para 85 casos em 2005. Em uma avaliação apresentada pelo SINAN, 78\% dos casos de co-infeção Leishmania/HIV refere-se ao sexo masculino. Entre as categorias, os heterossexuais corresponderam a 53\% em relação aos casos analisados.

A LV acomete principalmente crianças entre 10 anos de idade ou até menor. Isto decorre em função da imaturidade imunológica, entretanto, outros fatores, como exposição a animais, possivelmente infectados, e a deficiência nutricional são mencionados como relevantes para a ocorrência da LV nessa faixa etária. ${ }^{122,128-129}$ 
Ao considerar casos de óbitos por LVH, Ortiz \& Anversa $^{117}$ demonstraram uma alta taxa de letalidade com crianças menos de um ano. Além disso, um estudo com 431 crianças na faixa etária de 4 meses a 14 anos, revelou a ocorrência da doença nos primeiros 5 meses de vida, o que correspondeu a uma faixa etária de $68,2 \%$ dos doentes. ${ }^{130}$ A LV é apresentada por Desterro et al., ${ }^{129}$ como a principal causa de morbimortalidade em crianças no Nordeste Brasileiro.

Ao analisar os dados de 51 pacientes de zero a 12 anos, Xavier-Gomes et al. ${ }^{131}$ demonstram a maior incidência da doença em pacientes menor ou igual a 5 anos, o que correspondeu a $(78 \%)$ dos casos. Esses achados corroboram com o estudo de Pedrosa \& Rocha $^{128}$ no qual 55,3\% dos casos acometiam crianças abaixo de 5 anos de idade e de Brustolini et al. ${ }^{132}$, em que a doença predominou em $69,9 \%$ nos primeiros cinco anos de vida.

A LV está entre as principais doenças infecciosas de maior prevalência. 133-134 Discute-se ainda que o número de casos registrados podem ser ainda maiores, pois em alguns países a doença não é de notificação compulsória, o que dificulta o controle de investigações de casos. Além disso, os casos assintomáticos ou indivíduos expostos são superiores aos registrados. $^{\text {7,25 }}$

O panorama epidemiológico da LVH também é destaque em casos de co-infecção/ HIV. Desde 1980, a LVH é reconhecida como uma infecção oportunista associada a estados de imunodepressão, particularmente o HIV. Desde o primeiro caso de LVH associado à infecção pelo HIV, em 1985, a sua frequência vem aumentando rapidamente, principalmente no sul da Europa. Há registro de casos em 35 países ${ }^{116,118,135}$

A pandemia de HIV/AIDS tem modificado a história natural da LV, aumentando o risco de adoecimento em áreas endêmicas. ${ }^{118,136}$ De acordo com a OMS, dos 1.700 casos reportados de co-infecção LV/HIV até 1998, em 33 países, 85\% foram observados na Espanha, Itália, França e Portugal. Mais de $70 \%$ dos casos de LV em adultos estão relacionados com HIV-AIDS e 9\% de todos os pacientes sofrem de LV recém-adquirida ou reativada a partir de uma infecção antiga. ${ }^{137-139}$

O significado epidemiológico dessa expansão simultânea, discutidas em vários estudos, reside no fato de que os pacientes com HIV/AIDS, que vivem em áreas endêmicas de leishmanioses, apresentam maior risco de manifestá-la e que a co-infecção entre HIVLeishmania acelera o curso clínico da infecção por HIV. ${ }^{138-139}$ 
Fonte: WHO/NTD, 2015. ${ }^{6}$

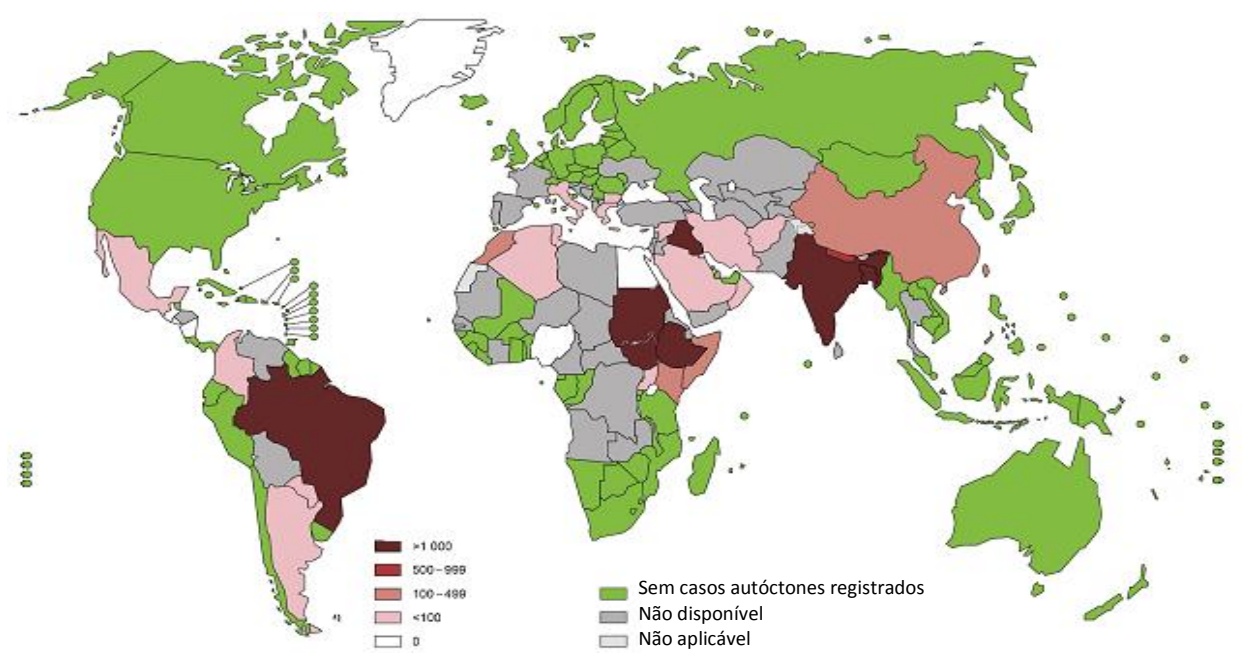

Figura 5. Distribuição Geográfica de Leishmaniose Visceral-LV no Mundo, 2012.

\subsubsection{Breve Histórico da LVH nas Américas}

As primeiras evidências da LV na América do Sul ocorreram em 1912, por Carlos Chagas, no Vale do Rio Amazonas, ao encontrar crianças com esplenomegalia sem causa justificada. $^{49}$

Nas Américas, a LV foi diagnósticada pela primeira vez por um médico paraguaio em Assumpção, em 1911, em um paciente oriundo de Corumbá/MS, no Brasil. ${ }^{140}$ (Oddone, 2012).

Alguns anos depois, a doença foi identificada na Argentina por Mazza, em 1926, com o relato dos primeiros casos na província de Salta, Inda, Vivoli e Vaccareza. Em 2006, o país apresentou o primeiro caso autóctone da LVH na cidade de Posadas. Deste ano até 2012, foram reportados 103 casos de LV. ${ }^{141-142}$

A LVH também foi descrita na Colômbia, México até o Norte da Argentina, atingindo ainda a Guatemala, Honduras, Nicarágua e Venezuela. ${ }^{13,38,116,143}$

De acordo com a WHO a LV é autóctone em 12 países das Américas, sendo registrado no período entre 2001-2013, um total de 45.490 casos com média anual de 3.499 casos. Em 2013, um total de 3.389 casos foi registrado em oito países distribuídos em 798 municípios. Os países que mais concentraram casos são Brasil, com 96\% (3.253) dos casos, seguidos do Paraguai 3,2\% (107) e Colômbia 0,4\% (13), (figura 6). ${ }^{7,13,25}$ 


\subsubsection{Evolução Histórica e Epidemiológica da LV}

O primeiro relato humano da LV no Brasil foi feito por Penna em $1934^{16}$ ao encontrar Leishmania Donovani em 41 fragmentos hepáticos analisados post-mortem em viscerotomias realizado em pacientes mortos com febre amarela oriundos das regiões Norte e Nordeste do Brasil.

Nessa ocasião, Carlos Chagas, até então, diretor do Instituto Oswaldo Cruz no Rio de Janeiro, incumbiu a Evandro Chagas uma investigação epidemiológica pelo Nordeste, pois os resultados de Penna sugeriram que esta região poderia ser o principal foco da $\mathrm{LV}$, particularmente o Ceará. ${ }^{4}$

De fato, em 1936, Evandro Chagas apoiado a sua comissão identificaram a prevalência da LV na região do Nordeste e ao Norte do país. Ainda neste período, a referida comissão, descreveu o primeiro caso vivo de LV no Brasil em um rapaz de 16 anos, irmão de outro caso falecido pela doença, cuja análise histopatológica do material de viscerotomia havia sido dada como positivo por Penna em 1934.

A comissão fez diagnóstico em alguns pacientes com a doença e encontrou a infecção em oito animais domésticos (sete cães e um gato). Chagas também aventou o envolvimento de animais silvestre no ciclo de transmissão, considerando-os como os principais reservatórios e excluiu a participação do homem e do animal doméstico na manutenção da doença no homem. ${ }^{49,144}$

Com vistas as suas investigações, a comissão assinalou a Leishmaniose Visceral Americana, como entidade mórbida e concluiram que a doença era restrita a ambientes rurais localizadas próximos a sítios com mata silvestre remanescente e caracterizada de transmissão esporádica. ${ }^{49,144}$

Nas décadas de 1930-1950, houve crescente fluxo de imigrantes europeus para os Estados do Rio de Janeiro e São Paulo, que sofriam o impacto demográfico em função da expansão da economia cafeeira e da incipiente industrialização, em detrimento da Região Sul, cujo fluxo imigratório teve característica de povoamento. Neste período, ao ser descrita pela primeira vez, a LV foi considerada como uma epidemia rural sem importância para a saúde pública, por causar casos esporádicos em regiões de baixas densidades populacionais e distante dos grandes centros urbanos. ${ }^{4,24,144}$

Na década de 1950, médicos da cidade de Sobral, no Ceará, por meio da detecção de um número anormalmente elevado de casos, alertaram a comunidade científica acerca do comportamento da LV que poderia ser diferente do que já sido descrito. ${ }^{4}$ 
Até esta década, pouco mais de 40 casos vivos foram diagnosticados e 240 exames histopatológicos de viscerostomia se mostraram positivos. No entanto, o frequente diagnóstico de imigrantes nordestinos com LV atendidos em grandes centros urbanos, como o Hospital das Clínicas da Universidade de São Paulo em 1954 e as comunicações de clínicos do Ceará relatando a existência de diversos casos naquele estado a partir de 1953. Isto motivou a Deane e colaboradores a investigar, na cidade de Sobral, a situação da doença entre 1953-1954. ${ }^{18,145}$

Tendo em vista o aparecimento de casos, neste período, iniciou-se a implementação de políticas de controle da doença no Ceará e em Minas Gerais, direcionadas ao controle do vetor e do reservatório doméstico em áreas rurais. ${ }^{146}$

A partir da década de 1960, há um intenso processo de urbanização, com a população urbana, ultrapassando a rural. Desde período até 1980, observa-se um considerável fluxo migratório rural-urbano em direção às grandes cidades em decorrência das condições ambientais (secas na Região Nordeste) e sociais desfavoráveis. Estima-se que neste período, saíram do campo em direção às cidades quase 43 milhões de pessoas, incluído o efeito indireto da imigração, ou seja, os filhos tidos pelos migrantes rurais nas cidades. ${ }^{24}$ Neste período há o surgimento de casos urbanos de LV. Além do fato, as medidas direcionadas ao controle haviam sido interrompidas. ${ }^{146}$

Em meados dos anos de 1980, constatou-se uma mudança drástica na distribuição geográfica da LV, ao atingir os grandes centros urbanos (figura 7). Neste período, surgem os casos nas periferias das grandes cidades: Rio de Janeiro (RJ), Corumbá (MS), Teresina (PI), Aracajú (SE), Natal (RN), São Luís e depois Belo Horizonte (BH), Montes Claros (MG), Camaçari (BA) e Recife (PE).

A expansão da doença, na década de 1980, incentivou a Superintêndencia de Campanhas de Saúde Pública-SUCAN, Ministério da Saúde, à retomada da implementação de estratégias de controle. ${ }^{146}$

O estabelecimento da LV nas cidades brasileiras é descrito a partir da década de 1980. O ano de 1981 marca a primeira epidemia urbana da LV no país, em Teresina, capital do estado do Piauí, na qual foram notificados 1059 casos em um período de 6 anos e com incidência, no período, de 190 casos/ 100.000 habitantes. Anteriormente, a este período, os casos identificados da doença restringiam-se a áreas rurais e pequenas aldeias da região. ${ }^{22,147}$ Após esta epidemia, a transmissão da doença expandiu-se para as demais capitais do Nordeste. $^{20-21}$ 
O registro da LV é reconhecido no estado do Piauí, desde 1934, sendo um dos principais focos da doença no Brasil. Apesar de não haver registros de epidemia neste período, foi observado um maior número de casos de 1953 a 1962, contudo, estes números são produto de investigação científica. Ao contrário das informações referentes a outras épocas que dizem respeito, em sua maior parte, a munícipios proximos à cidade de Sobral, Estado do Ceará, sede de investigações epidemiológicas da LV. ${ }^{21}$

A literatura reconhece a urbanização da LV a partir da epidemia de 1981, no Estado do Piauí. Porém este fenômeno é mais antigo. ${ }^{21,22}$ Deane, em 1955 comprovou a existência da transmissão da LV no meio urbano e que os principais fatores para a ocorrência da doença são a concentração da população e as condições favoráveis para a manutenção do ciclo de transmissão da LV. ${ }^{18}$

Fonte: Harvay et al., 2011 (adaptado). ${ }^{23}$

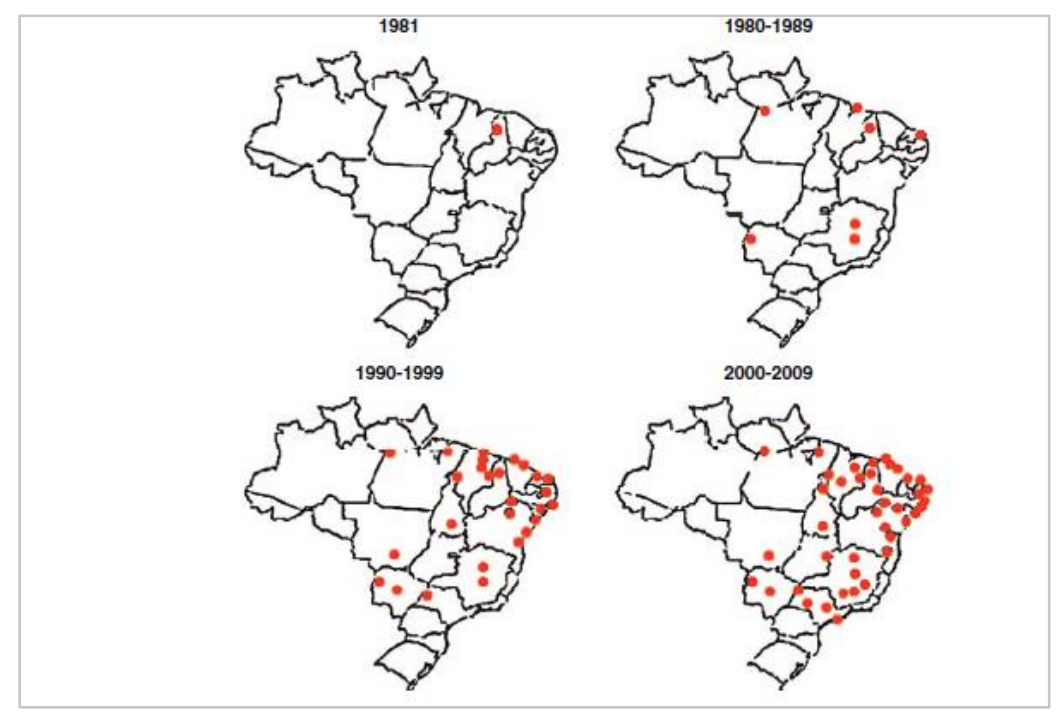

Figura 6. Expansão da Leishmaniose Visceral Humana no Brasil. 1981-2009. Pontos em vermelhos indicam cidades com mais de 100.000 habitantes e mais de 10 casos de Leishmaniose Visceral.

\subsection{MANUTENÇÃO DA LV NO AMBIENTE URBANO}

Considerando o acelerado processo de urbanização verificado no Brasil na segunda metade do século XX e a elevação da complexidade do espaço urbano, há uma intensificação demográfica, marcada pela elevada concentração humana em cidades de forma desordenada, especialmente em regiões suburbanas, comprometendo, dessa forma, as condições de infraestrutura e saneamento básico. ${ }^{148}$ 
O impacto negativo do crescimento das cidades se deve principalmente às alterações antrópicas no meio ambiente. Destaca-se, neste contexto, o desmatamento e a construção de casas sem infraestrutura em locais próximos a matas remanascentes. A criação de animais no peridomicilio propiciaria a adaptação do vetor, alterando o ciclo natural do L. longipalpis, o qual se alimenta de uma grande variedade de hospedeiros. Além do hospedeiro humano, há o envolvimento de algumas espécies de aves, animais domésticos e silvestres. ${ }^{23}$ Sousa et. al, ${ }^{149}$ aventam que a mudanças na ecologia do L. longipalpis resultam, por exemplo, no aumento da população de insetos vetores e reservatórios do parasito na área urbana, o que serviria para explicar as características epidemiológicas do meio urbano. ${ }^{91,150}$

A falta de saneamento e a disposição inadequada do lixo também são consideradas nesse âmbito, por atrair o vetor e ou reservatórios selvagens ao peridomicilio, contribuindo dessa forma para o aumento do risco de infecção das populações humanas e caninas susceptíveis. ${ }^{91,151}$

Para o entendimento da manutenção do ciclo da transmissão da LV, sugere-se uma interdependência entre os ciclos, as quais envolvem a existência de uma transmissão silvestre associada ao meio urbano e promovida por mamíferos silvestres, como raposas, cães e gambás, que habitam vizinhanças da área urbana (Figura 8). ${ }^{4,20,23}$ Dantas-Torres discute o papel do cão e os demais animais domésticos, os quais atuam como amplificadores da infecção para o humano, e estes, por sua vez, ao habitarem em condições precárias, permitem a manutenção da transmissão da doença na área urbana. ${ }^{153}$

Fonte: Laison \& Rangel (2005) ${ }^{4}$

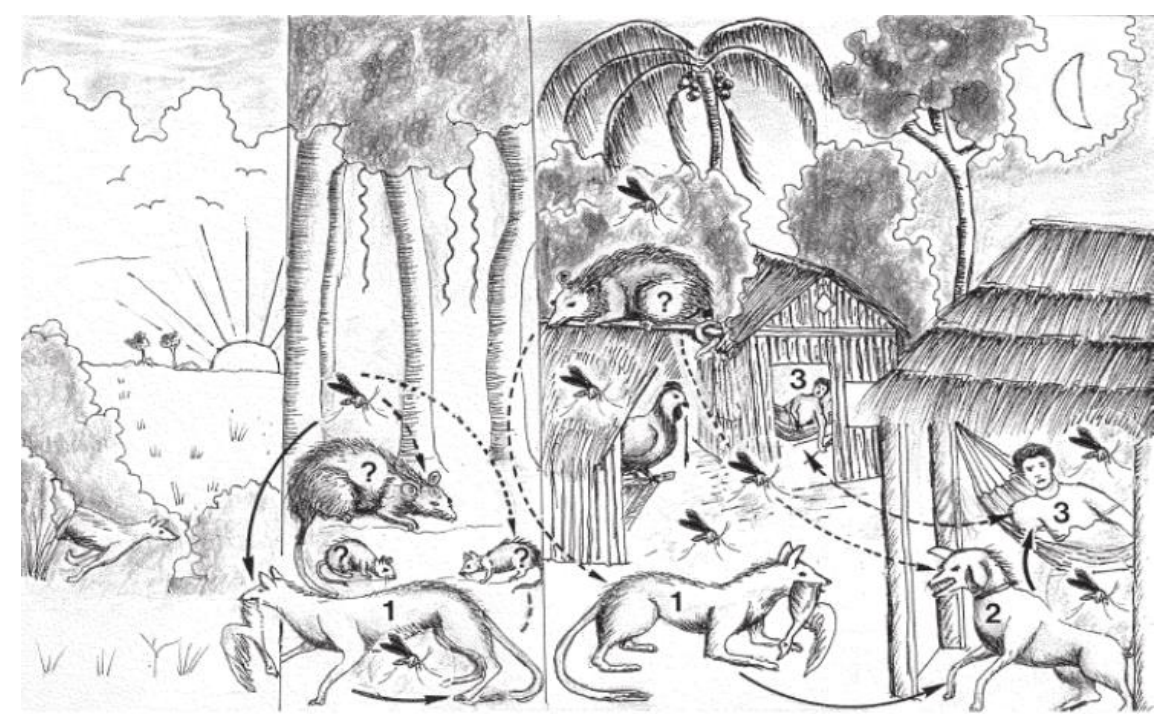

Figura 8. Eco-epidemiologia da LV. O parasito Leishmania infantum, enzoótico proveniente de raposas silvestres e também de outros animais selvagens (1), é mantido em uma população silvestre do mosquito palha Lutzomya longipalpis. Invasão de moradores na borda de floresta por este flebotomineo permite o 
estabelecimento da infecção canina e humana (2,3), e o cão doméstico torna-se a principal fonte para o parasito. Linhas contínuas rotas definadas de transmissão. Linhas tracejadas representam possível transmissão com outros animais selvagens, e o próprio homem servindo como fonte de infecção pata flebotomíneos.

O cão doméstico (Canis familiaris) é o principal reservatório da LV na área urbana, e atua como um elo na transmissão da doença. ${ }^{13,90}$ A enzootia canina tem sido relatada como precursora dos casos humanos. Bevilacqua et al. ${ }^{19}$ demonstraram que os casos caninos em Belo Horizonte precederam aos dos casos humanos, confirmando a importância do cão como reservatório da doença no ambiente urbano. Isso indica que ambos os casos podem apresentar fontes de infecção comuns. Entretanto, esse processo ainda não está elucidado. ${ }^{23,34,91,152}$ Embora a presença do cão infectado na área urbana seja um dos principais fatores responsáveis pelo aumento dos casos de infecção humana, Marcondes \& Rossi ${ }^{7}$ discutem que o elevado número de casos de animais assintomáticos, que pode chegar a $80 \%$ da população infectada, serve como reservatórios para o vetor e que a ausência de sintomas dificulta a identificação desses cães. Nesse sentido, Baneth et al. ${ }^{154}$ aventam que essa condição canina pode estar associada aos resultados falsos negativos nos testes sorológicos. Por essa razão, a alta prevalência de cães assintomáticos é apontada como determinante para a manutenção do ciclo de transmissão da LV. Laurent et al. ${ }^{155}$ comprovaram que os cães assintomáticos são altamente competentes para estabelecer a infecção em flebotomíneos, demonstrando o seu papel no ciclo epidemiológico da LV no ambiente urbano. 


\subsection{PRINCIPAIS EPIDEMIAS URBANAS NO BRASIL}

A LVH é uma doença de caráter endêmico no Brasil. No período de 1984 a 2002 aproximadamente 66\% dos casos ocorreram nos Estados da Bahia, Ceará, Maranhão e Piauí. Em 2003, os estados que apresentaram as maiores taxas de incidência foram em Tocantins, Piauí, Maranhão, Mato Grosso do Sul e Roraima. ${ }^{61}$ Atualmente, com a urbanização da LV, a doença tornou-se endêmica nas capitais brasileiras de Fortaleza (CE), Araguaína (TO), Belo Horizonte (BH) e Campo Grande (MS).

Entre 1980 a 2005, o Brasil registrou 59.129 casos da doença, com uma média anual de 2.274 casos novos e 2.911 mortes. De todos os casos, 82,5\% ocorreram na Região Nordeste. Em contrapartida, nas regiões Norte, Centro Oeste e Sudeste, os casos correspondiam a 15\%. Já em 2005, essas regiões apontam um aumento de $44 \% .^{23,157}$ Elkhoury apresenta o registro de 1.904 casos (34,2\%) quanto a populações indígenas em diferentes munícipios brasileiros. ${ }^{5}$

Entre 1992 a 1995, registrou-se mais de 1.140 casos da doença em Teresina. Para Drummond \& Costa, ${ }^{147}$ o pior cenário da doença na região ocorreu em 1993, quando se observou uma variação cíclica, com taxas de incidência baixas que duraram até 1998. Após esse período, houve um aumento significativo de casos, com expansão da doença pelas demais áreas urbanas da região nordestina.

Após o surto nessa região, ocorreram outras epidemias urbanas em Natal, Montes Claros (MG), São Luís (Maranhão), Belo Horizonte (MG), Várzea Grande (MT), Palmas (TO), Araçatuba (SP), Fortaleza (CE) e outras. ${ }^{22}$

Além destes estados, outros também apresentaram casos notificados de LVH: Alagoas, Bahia, Piauí, Rio Grande do Norte, Rio de Janeiro, Roraima, Sergipe, São Paulo, Tocantins, São Paulo, Espírito Santo, Goiás e Distrito Federal-DF. ${ }^{61,157}$

Em um estudo que retrata a urbanização da LV no estado do Ceará realizado por Cavalcante \& Vale, ${ }^{119}$ observou-se que a região metropolitana de Fortaleza detém o maior número de casos da doença no Estado e a cidade de Fortaleza é o munícipio com o maior número de caso do País.

Os casos urbanos de LVH em Belo Horizonte são registrados desde 1993, introduzidos a partir de um munícipio vizinho. De acordo com a literatura a ocorrência de casos humanos precedeu aos casos caninos. Em 1992, foram diagnosticados cães positivos no município e, em 1994, surgiram os primeiros casos urbanos nas regiões limítrofes do 
munícipio de Sabará, onde um caso havia sido confirmado em 1989. A LVH, que apresentava uma endemia local, tornou-se amplamente distribuída na capital. ${ }^{152,158-160}$

Desde então, a doença se expandiu por todo o município. Em Paracatu-MG, por exemplo, de 2007-2010, foram registrados 128 casos. Segundo os autores, o munícipio apresentou alta incidência, necessitando desta forma de uma reavaliação local das estrategias de medidas de controle. ${ }^{161}$

Por fim, Gonçalves et al. ${ }^{162}$ relatam que em 19 anos de história desde o caso índice, já foram reportaram 1568 casos humanos e 225 óbitos. Para Silva et al. ${ }^{163}$ os movimentos migratórios da população para as periferias da cidade, adaptação do L. longipalpis e determinadas mudanças ambientais, favoreceram a manutenção da LV na região.

No período de 2000-2004, foram reportados 83 casos e 133 casos/ano entre os anos de 2005-2010. Esses dados corroboram com as evidências de um estudo de caso apresentado por Harvay et al. ${ }^{23}$ no qual demonstrou-se um aumento significativo de casos para esse período. ${ }^{164}$

Um estudo realizado por Luz et al. ${ }^{165}$ revela que de uma análise parcial de 168 fichas de notificação de LV no Munícipio de Belo Horizonte, mostra que 91,4\% dos casos autóctones residiam de áreas urbanas.

Essa situação epidemiológica revela que não houve redução na letalidade no Estado apesar das medidas adotadas pela vigilância local. A letalidade variou de 8,2\% em 2007 a 22\% em 2009. ${ }^{164,166,167}$ Em Montes Claros, fatores como pobreza, desnutrição, grande número de cães infectados, alta densidade de flebotomíneos, condições sanitárias precárias e baixos índices sócio-econômicos foram considerados relevantes para ocorrência da LVH na região. ${ }^{150}$

A avaliação dos casos de LV ano de 2004, permitiu a Borges ${ }^{168}$ concluir que dentre os principais fatores de risco da LVH em Belo Horizonte destacam-se a quantidade de cães no domicilio, condição de moradia da população e a presença de animais e plantas no peri e intradomicilio.

No Estado de Sergipe, desde a primeira descrição de um caso humano de LV feita por Evandro Chagas em 1938, há o registro periódico de novas ocorrências da doença na região. Nas décadas de 30,40 e 50 foram registrados 28 casos, no período de 1972 a 1998 foram notificados 1.874 casos. $^{91}$

Em relação ao ano de 2003, Goes et al. ${ }^{91}$ discutem que houve uma tendência de queda no número de casos. No entanto, a incidência da doença mostrou-se ascendente. Um 
levantamento realizado por Góes et al. ${ }^{118}$ no período de 2007-2011 apresenta a notificação de 128 casos de LVH no munícipio de Aracajú com uma média de casos de 25,6 casos por ano.

Acredita-se que em 1934, o estado do Maranhão observava o seu primeiro caso de LV, sendo o diagnóstico feito por através de viscerotomia por Madureira Pará. ${ }^{169}$ Em 1961, Alencar afirmava que a migração de outros estados Nordestinos, tornaria o estado como um novo foco da doença. Fatos até então constatados, pois até 1967, haviam sido diagnósticados e notificados 53 casos por viscerotomia e dois casos autóctones do Município de São José de Ribamar, localizado na Ilha de São Luis, relato feito por Fiquene. ${ }^{170}$

Em 1974, Brandão ${ }^{171}$ escreveu o primeiro caso autoctone da doença. Desde período até 1981, não houve relato da ocorrência da LV no estado. Até que, em 1982, Silva et al., ${ }^{172}$ diagnosticaram a doença em quatro crianças de uma mesma família residente na periferia de São Luís, descrevendo no mesmo ano um total de 39 casos autóctones de LV, instalando uma um situação epidêmica com expansão da doença para outras áreas da Ilha de São Luís. ${ }^{172}$

Ao investigar o comportamento da LV no Maranhão, no período de 1982-1993, Desterro et al. ${ }^{129}$ discutem a predominância de casos da doença na Ilha de São Luís, em áreas periurbanas. O surto nessa região é explicado principalmente pela estiagem do período, o que provocou um intenso processo migratório. Essa condição é semelhante a outros estados nordestinos, como o Piauí e Ceará. ${ }^{21,174-175}$ Estudos esclarecem que de 1982 a 1986 a situação epidêmica da LV se manteve com o registro de 1.124 casos. Após esse período, houve um declínio da doença. Questionam-se os fatores que promoveram a diminuição da incidência de casos na região: efetividade das medidas profiláticas ou há a influência de outros fatores (periodicidade, sazonal, esgotamento de sucetíveis, declínio de espontâneo).

De 1988 a 1993, houve uma expansão principalmente das áreas suburbanas da Ilha cujas características também foram identificadas em outras áreas endêmicas nordestinas e do restante do país, estabelecendo, assim, o quadro de LV urbana, diferentes da doença observada em casas de pés de serra. Os casos de LVH espalharam-se nos locais onde se concentrou o fluxo migratório. ${ }^{175-176}$ Para Costa et al. ${ }^{173}$, a partir de 1988, o estado do Maranhão, juntamente com o Piauí e Ceará, se transformaram em áreas de maior problema da LV no Brasil.

Em Mato Grosso, os primeiros casos autóctones ocorreram em 1973 no munícipio de Guiratinga, com o registro de oito casos humanos. Durante duas décadas, questionou-se a transmissão da LV e a sua autoctonia no respectivo Estado. Contudo, em 1998, quatro novos casos surgiram no Centro Sul do País. Em 1998, registrou-se o primeiro caso em Cuiabá. ${ }^{177}$ 
Em Jaciara, Brito et al. ${ }^{178}$ 2014) demonstram no período entre 2003-2012 a ocorrência de 128 casos no munícipio.

Em 2000, a L. longipalpis foi identificado pela primeira vez em Campo Grande. Por conseguinte, no ano de 2002, foram notificados os primeiros casos autóctones de LVH na região, caracterizando o início da epidemia na capital do Estado, a qual se estendeu até 2006 com o registro de 568 casos humanos da doença. ${ }^{127,179}$

Inicialmente a doença estava restrita a dois munícipios, Corumbá e Ladário, e após 1995, a LVH disseminou-se por outras áreas urbanas, sendo registrado em 34 dos 78 munícipios do Estado. Há destaque para um caso de epidemia em Três Lagoas no ano de 2001. ${ }^{179}$

Na região Norte do País, Guerra et al. ${ }^{180}$ descreve o perfil epidemiológico da LV entre Indios no estado de Roraima. Em 1989, foi revelado o primeiro caso autoctone da doença. Contudo, o maior número de casos foi registrado em 1991 com 26 ocorrências $(31,7 \%)$. Em seis municipios, dentre os oito existentes à epoca no Estado de Roraima, registraram-se 82 casos de LV.

Em um estudo epidemiológico, no período entre 2001 a 2006, Botelho et al. ${ }^{123}$ analisaram 577 fichas de notificação de LV. Os resultados demonstraram uma incidência de 1,47 casos/100.000 hab em 2001, chegando a 20,98 casos/100.000 hab em 2006, com notificações todos os meses a partir de 2002.

As modificações ambientais que permitiram a adaptação do vetor à área urbana, associada à migração da população, foram determinantes para a epidemia de LV no Estado de Mato Grosso do Sul. ${ }^{61}$

Um panorama epidemiológico apresentado por Werneck et al. ${ }^{22}$ demonstra que em 30 anos da doença no Brasil foram reportados por ano um aumento de 1.601 (1985-1989) para 3.816 (2008-2012). Para esse período, o Nordeste ainda é destaque em número de casos em relação às demais capitais brasileiras. A proporção de casos autóctones correspondeu a $80 \%$. É visto que em 2007, registrou-se 50\% dos casos, o qual permaneceu estável até essa data. Werneck et $a l^{22}$ discutem que a diminuição de casos nesse período ocorreu em razão da introdução da doença nas demais capitais do país com população de mais de 100.000 habitantes como Belo Horizonte (MG), Campo Grande (MS), Teresina (PI) e Palmas (TO). 


\subsubsection{Características Epidemiológicas da LVH no Distrito Federal}

De acordo com o Ministério da Saúde, no Distrito Federal-DF, havia registros de casos desde 2000. Entretanto, registros do Hospital Universitário de Brasília - HUB revelaram a ocorrência da doença desde 1983. Carranza-Tamayo et al. ${ }^{157}$ discutem que os casos reportados são de transmissão autóctone oriundo a municípios que circundam a cidade cuja ocorrência é registrada antes de $2005^{157}$. No entanto, Cardoso ${ }^{181}$ discute que a transmissão da LV ocorreu neste período na região Norte da cidade, na qual foi diagnosticado o primeiro caso suspeito autóctone.

A maioria dos casos registrados no DF é oriunda de regiões próximas à cidade de Goiás, Bahia e Minas Gerais. De acordo com Almeida et al. ${ }^{64}$ no período entre 2001-2012, foram confirmados 3.321 casos de LV na região Centro-Oeste, incluindo Mato Grosso do Sul (MS), Goiás (GO) e DF. Já 2014, foram confirmados três casos de LVH no DF, dos quais apenas um foi considerado autóctone, proveniente da região administrativa do Jardim Botânico, Brasília-DF. Os outros dois casos foram importados da Bahia e Piauí. ${ }^{13,157,182}$

\subsection{ASPECTOS GERAIS DA RESPOSTA IMUNOLÓGICA CONTRA LEIHSMANIA}

\subsubsection{Imunidade Celular}

A resposta imune a LVH inicia-se pela ativação do sistema fagocitário mononuclear, após a entrada do parasito às células do hospedeiro e sua consequente multiplicação, principalmente no fígado e baço, promovendo assim a ativação da resposta imunológica à infecção por Leishmania. As formas promastigotas do parasito são fagocitadas por neutrófilos, que são as primeiras células a migrarem para o local da infecção. ${ }^{44}$

Os patógenos, dentre eles os protozoários, podem ser reconhecidos por fagócitos através das proteínas moleculares associadas ao patógeno (PAMPs) que interagem com os receptores de reconhecimento (PPRs) expressos nos fagócitos. Como não conseguem penetrar ativamente, dependem da ação fagocítica das células, principalmente através da interação entre receptores celulares do hospedeiro (CR1, CR3, manose-fucose) e moléculas de superfície do micro-organismo, principalmente as lipofosfoglicanos (LPG) e a protease de superfície (gp63). ${ }^{183}$ 
Acredita-se que essa ação de reconhecimento esteja envolvida com a ativação da imunidade inata e também como sinalizadora para a cascata de eventos mediada pela imunidade adquirida. ${ }^{184}$

Os TLRs são famílias de transmembranas com estrutura altamente conservada que reconhecem produtos do metabolismo (PAMPs), que ativam uma resposta imunológica específica ao patógeno. Esse reconhecimento pode envolver a produção de múltiplos TLRs. Um das funções desses receptores é mediar à maturação de células dendríticas. Contudo, a interação entre TLRs com PAMPs desencadeará a ativação de fatores de transcrição envolvidos com a ativação de genes que codificam diversas citocinas e síntese de outras moléculas. ${ }^{185-188}$

As espécies de Leishmania apresentam algumas classes de proteínas que estão envolvidas com a virulência e a resposta imunitária do hospedeiro ao parasito. As proteínas A2 e LMPK são expressas em promastigotas. Vistas como fatores de virulência em várias espécies de Leishmania, desempenham um papel importante na sobrevivência do parasito na célula hospedeira. $^{189}$

Outros fatores de virulência, como LPG, cisteína proteinase, gp63 e CRK3 são determinantes para a sobrevivência do parasito na célula hospedeira. ${ }^{190-193}$

A localização da Leishmania spp é predominantemente no vacúolo parasitóforo (VP) podendo residir individualmente ou em grandes vacúolos com várias formas amastigotas. Uma vez dentro dos fagócitos mononuclear, as promastigotas sofrem significantes alterações bioquímicas e metabólicas, as quais resultam na forma intracelular obrigatória amastigota. Essas formas do parasito desenvolvem mecanismos de escape dos macrófagos, podendo reinvadir células dendriticas e fibroblastos, bem como novos macrófagos. ${ }^{194-195}$

A principal forma de liberação das formas amastigotas no meio extracelular é por ação mecânica com a elevada multiplicação dos parasitos no ambiente intracelular. ${ }^{196}$

$\mathrm{Na}$ fase inicial da infecção por Leishmania, os neutrófilos são importantes para controlar a disseminação da infecção. Isso se deve principalmente ao fato de que essas células secretam quimiocinas como IL8 e MIP-1 $\beta$, que são moléculas importantes para atrair mais neutrófilos e macrófagos para o sítio da infecção. ${ }^{197}$

Estudos recentes demonstram que a entrada e a sobrevivência de Leishmania spp dentro de macrófagos ocorrem apenas quando há a prévia infecção de neutrófilos recrutados como uma resposta normal à picada do inseto. Outras análises discutem que Leishmania spp 
são capazes de infectar os neutrófilos, sendo estes fagocitados por macrófagos, e desencadear um processo nos macrófagos conhecido como modelo "Cavalo de Tróia". 198

As formas promastigotas são fagocitadas pelos neutrófilos, que são as primeiras células a migrarem para o local da infecção e podem ser destruídas pela ação do metabolismo oxidativo, o peróxido de hidrogênio $\left(\mathrm{H}_{2} \mathrm{O}_{2}\right)$, atividade enzimática e oxido nítrico. Os neutrófilos, por sua vez, secretam quimiocinas, tais como IL8 e MIP $\beta$ e outras moléculas importantes que atrair mais neutrófilos e macrófagos para a infecção. (Bacellar \& Carvalho, 2005).

Nas leishmanioses, em geral, a resposta imune celular é considerada a mais importante em relação à resistência e a susceptibilidade. No tocante à $\mathrm{LVH}$, a resistência à infecção está associada à ativação de células $\mathrm{CD}^{+}, \mathrm{CD}^{+}$e a produção de citocinas como IL2, IFN- $\lambda$, e IL12. Já a susceptibilidade por sua vez envolve a síntese de IL10 e o fator de necrose tumoral- $\lambda(\mathrm{TNF}-\alpha)$ e, desse modo, ativam os macrófagos a destruírem as formas amastigotas intracelulares via produção de óxido nítrico. ${ }^{200}$

Em camundongos resistentes, as células $\mathrm{CD}^{+}$ativam a óxido nítrico sintetase (iNOS ou NOS2), levando estímulo à ação microbicida mediada por óxido nítrico (NO). Em LVH, o NO dentro do macrófago é considerado um importante leishmanicida, por meio de sua ação citotóxica e citostástica promovem a destruição da Leishmania, auxiliando no controle da infecção. ${ }^{200}$ A liberação do NO leva à morte do parasito em macrófagos humanos, que podem também ser estimulados pela ação de quimiocinas como MCP1 e MCP-1 $\alpha$.

$\mathrm{Na}$ infecção parasitária, os macrófagos apresentam múltiplas funções: serve como células hospedeiras na multiplicação do parasito, como célula apresentadora de antígenos e como células produtoras de citocinas moduladoras da resposta mediada pelo linfócito $\mathrm{T}$. A atividade leishmanicida do macrófago está na dependência da produção do fator de crescimento e transformação $\beta$ (TGF $\beta$ ), a ação dessas citocina está relacionada com a desativação do macrófago, inibição do IFN入 e redução da molécula da expressão $\mathrm{MCH}$ classe II. Além disso, medeia a ativação de células Th1 que agem sobre os macrófags oinfectados como efetores para a morte intracelular do parasito. ${ }^{197,201}$

No processo de infecção, a Leishmania consegue evadir aos eventos microbicidas do sistema imune do hospedeiro, utilizando-se dos mecanismos como inativação do sistema complemento, modulação da produção de citocinas e quimiocinas; interferência nos processos de migração; apoptoses celulares e modificação do ambiente intracelular. ${ }^{183}$ 


\subsubsection{Imunidade humoral}

A resposta humoral é reconhecida no processo infeccioso pela elevada produção de anticorpos e também de células $\mathrm{T}$, que podem surgir no início da infecção, ou até mesmo, antes das alterações na resposta imune celular. ${ }^{199,202}$

Em um estudo experimental, com antígenos específicos de leihsmania foi revelado principalmente à presença de anticorpos das classes $\operatorname{IgG}, \operatorname{IgM}$ e $\operatorname{IgE}$ na fase ativa da doença. Nascimento et al. ${ }^{203}$ sugerem que a produção desses anticorpos estejam envolvidos com a patogênese da doença. Para Saha et al. ${ }^{202}$ a elevação de anticorpos pressupõe uma resposta imune natural, principalmente em indivíduos assintomáticos que residem em áreas endêmicas.

Nos estudos de Atta et al. ${ }^{204}$ foi observada níveis séricos de $\operatorname{IgE}$ total e frações específicas de IgE em indivíduos com LVH em diferentes formas clínicas da doença, associando os seus níveis a gravidade da doença e a resposta terapêutica.

No processo de infecção por Leishmania, a imunidade humoral também é destaque por uma alta produção de gamaglobulinas no soro e pelas reações sorológicas positivas. Em humanos, o IgG aumenta rapidamente e pode representar $50 \%$ do total de proteína séricas. Logo que os sinais e sintomas desaparecem, caem os títulos também, mantendo-se positivos por muitos anos, na grande maioria dos casos tratados. ${ }^{203}$

A imunossupressão é descrita como a principal disfunção imunológica. Essa resposta celular pode ser avaliada por meio de teste de hipersensibilidade tardia antígeno específico (Teste de Montenegro) bem como por proliferação de células mononucleares de sangue periférico. Os responsáveis por essa imunossupressão na LV, presença de células aderentes, fator sérico supressor receptor solúvel de IL-2, defeitos nas células apresentadoras de antígenos, TGF $\beta$ que 0estaria inibindo a função do macrófago, moléculas co- estimuladoras e por fim a diminuição na produção de óxido nítrico NO. ${ }^{200,205}$

Em indivíduos acometidos por LV, a atuação da imunidade humoral é reconhecida por uma alta produção de gamaglobulinas no soro e pelas reações sorológicas positivas. Há superprodução de imunoglobulinas da classe $\operatorname{IgG}$ devido uma desregulação no sistema imunológico e também produção de anticorpos específicos. Em humanos, o título de Ig aumenta rapidamente e pode representar $50 \%$ do total de proteína séricas. Logo que os sinais e sintomas desaparecem, caem os títulos também, mantendo-se positivos por muitos anos, na grande maioria dos casos tratados. ${ }^{203}$ 


\subsubsection{Imunopatogenia da LV}

A interação da L.chagasi e a resposta imune celular resultam em um amplo espectro de manifestações clínicas da doença. A sucetibilidade à doença é marcada por uma resposta do tipo Th2 com a produção de IL4 e IL10, inibição de macrófagos e consequente proliferação dos parasitos. Em contrapartida, alguns estudos experimentais, sugerem que uma resposta imune do tipo Th1 com a produção de IFN $\delta$, caracterizam um mecanismo Leishmanicida de resistência. ${ }^{206,207}$

$\mathrm{Na}$ interface da resposta imune Th1 e Th2, alguns indivíduos podem apresentar uma condição clínico-imunológica oligossintomática, cujos achados clínicos e imunológicos não estão claramente definidos. ${ }^{208}$

Admite-se que a espécie de Leishmania influencie o padrão de resposta do linfócito T, deprimindo a atividade macrofágica. Assim, linfócito T-CD4 parasitos específicos (Th1), secretam interferon-gama, o que estimula os macrofagos a produzirem fator de necrose tumoral alfa. E este, ativa os fagócitos para eliminarem parasitos via metabólitos tóxicos (peroxido de hidrogenio e ácido nítrico). Já o linfócito T-CD4 (Th2), secretan interleucina 4, que inibe a ativação de macrofagos, via interferon-gama,com consequente inibição do fator de necrose tumoral alfa. Em função disso, poucos pacientes infectados desenvolvem a doença. ${ }^{209}$

Análises experimentais em humanos demonstram uma resposta imunológica, após a infecção por Leishmania, com predomínio dos linfócitos $\mathrm{T}$ auxiliares (Th2) e inadequada produção de interleucina-2 (IL2) e gama-interferon na fase sintomática doença. No estudo, observou-se uma restauração de seus níveis após tratamento adequado. ${ }^{210}$

Ainda, um estudo realizado após a inoculação de promastigotas de L. major na derme de murinos, demonstrou-se um processo inflamatório na área inoculada, sendo observada uma quantidade considerável de neutrófilos no local da lesão. ${ }^{211}$

A depressão da resposta imunológica mediada por células é marcante na LVH. Indíviduos na fase ativa da doença são incapazes de produzir IFN $\delta$ e IL2, quando estimulados com antígenos de Leishmania, inativando os mecanismos de destruir do parasito pelos macrófagos, mas fatores séricos presentes na doença ativa são capazes de suprimir a resposta proliferativa. A incapacidade do hospedeiro de desenvolver uma resposta imunológica eficaz à infecção por Leishmania está relacionada a diversos aspectos da imunidade celular: diferenciação dos linfócitos, apresentação dos antígenos, produção de citocinas e ativação dos mecanismos de lise dos macrófagos. ${ }^{32}$ 


\subsection{PATOGENIA}

A patogenia da LVH é influenciada por fatores inerentes ao hospedeiro, como as suas características genéticas e imunológicas; por fatores relacionados à Leishmania spp, como sua patogenicidade e virulência; e pelo vetor com a sua capacidade vetorial. Em decorrência dessa interação, a um espectro de manifestações clínicas, histo e imunopatológicas que podem ser observados no homem. ${ }^{212}$

O período de incubação da doença é bastante variável, 10 dias a 24 meses, com média entre dois a seis meses e, geralmente apresentando evolução indiciosa. O primeiro sinal de visceralização é febre baixa recorrente com dois ou três picos diários que persiste com remissões durante toda a infecção. Associado a esse estado febril, a esplenomegalia é outro sintoma que caracteriza um individuo suspeito de LVH. ${ }^{8,13,117,206}$ Em pacientes não tratados, ocorre progressiva desnutrição multifatorial devido à inapetência. ${ }^{20,13}$

Os sinais sistêmicos típicos estão associados a um estado febril intermitentes, palidez cutâneo-mucosa, esplenomegalia associada ou não à hepatomegalia, um estado progressivo de emagrecimento e enfraquecimento geral do indíviduo. Na doença abrupta, os pacientes com HIV, podem ir a óbito antes mesmo dos sintomas terem se desenvolvido. Os sinais mais frequentes são hemorragias gástricas e ictéricas. ${ }^{210,212,214}$ A disseminação das Leishmanias ocorre via hematogênica e/ou linfática. Esse parasito, com tropismo por células do SFM, penetra no macrófago e se transforma em amastigota e concentra o seu parasitismo em órgão onde essas células são numerosas, como medula óssea, baço e fígado. ${ }^{20-15}$

Na medula, é visto uma hipoplasia medular e consequente pancitopenia periférica. No baço, é observada uma esplenomegalia devido à congestão do sinusoides e hiperplasia do SER, principalmente de macrófagos e plasmócitos. No fígado, observa-se hepatomegalia com hipertrofia e hiperplasia difusa das células de Kupffer. ${ }^{215-217}$

O agravamento renal em indivíduos com LVH é marcado por uma glomerulonefrite e lesões nos túbulo intersticiais severas. Em função disso, há ocorrência de albuminúria e hematúria. Salgado-Filho ${ }^{218}$, ao analisar 10 pacientes com LV na fase aguda, observou a presença de síndrome nefrítica aguda em dois pacientes, constituindo, dessa forma, um achado clínico de grande relevância para o diagnóstico clínico da doença. ${ }^{219-220}$

A análise de exames laboratoriais em pacientes com LV demonstram alterações na concentração de proteínas. Este fato correlaciona o envolvimento renal com o quadro clínico de edema, um sinal característico da doença. ${ }^{221,218}$ 
A respeito dos indíviduos co- infectados Leishmania-HIV, as manifestações clínicas são febre, esplenomegalia e hepatomegalia, semelhantes as dos casos dos indivíduos imunocompetentes. Embora Pintado \& Colaboradores ${ }^{222}$ reforcem em seus achados que nos pacientes co-infectados Leishmania-HIV, a esplenomegalia apresentou menos incidência quando comparado à dos indivíduos HIV negativos (80,8\% versus 97,4\%), sendo esta estatisticamente significativa $(\mathrm{p}=0,02){ }^{135,223}$

A importância da LV em indíviduo infectado pelo HIV se dá pelo fato da parasitose, acelerar a progressão desta infecção, ao promover a replicação viral, agravando ainda mais o estado de imunodepressão. Estudos in vitro demonstram que o HIV induz a replicação de Leishmania pela diminuição de células $\mathrm{T}$ que são capazes de reconhecer os antígenos desse parasito. Além da Leishmania, o HIV pode invadir os macrófagos, mesmo sendo as células $\mathrm{CD}^{+}$, as preferenciais. Por fim, acredita-se em uma atuação sinérgica desses patógenos na potencialização dessas infecções em pacientes co-infectados. ${ }^{127,224}$

\subsubsection{Aspectos clínicos}

A LVH é uma doença de evolução crônica com período de incubação de 3 a 6 meses, podendo chegar a anos. Em áreas endêmicas, a maior parte dos indivíduos é reconhecida como assintomáticas curando-se espontâneamente restando apenas o IDRM como evidência de infecção prévia. ${ }^{225}$ Cerca de 20 a $30 \%$ podem desenvolver manifestações clínicas que variariam desde indivíduos oligossintomáticos até com a sintomatologia mais intensa. ${ }^{36,226}$

A LVH apresenta-se clinicamente como doença de evolução arrastada, caracterizada por febre baixa recorrente, tosse seca, sudorese e prostração. Outras manifestações clínicas se desenvolvem com a progressão da doença, em especial a diarréia, ícterícia e edema periférico. $13,130,210,221,227$

No exame clínico, é possível verificar-se hepato e/ou esplenomegalia discreta a moderada (figura 9). Com a evolução do quadro desenvolve-se desnutrição, incluindo, cabelos quebradiços, cílios alongados, alterações de pele e das unhas. ${ }^{13,210}$ 
Fonte: WHO/NTD, $2015^{6}$

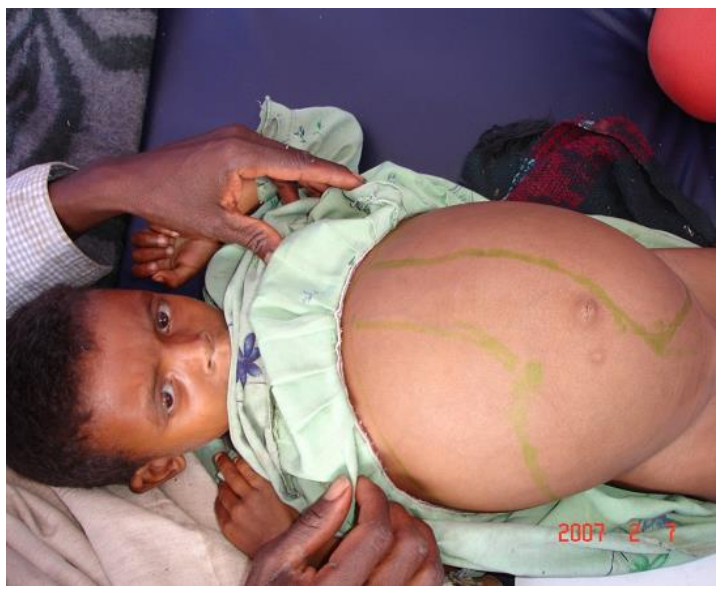

Figura 7. Paciente com hepatomegalia (adaptado)

Em relação ao quadro hematológico, a LV pode evoluir para formas graves com desordens hematológicas expressivas, incluindo: pancitopenia (anemia, trombocitopenia e leucopenia com neutropenia, marcada eosinopenia e uma relativa linfocitose e monocitose), hemólise, fibrinólise, entre outras. ${ }^{228}$

A depressão da produção de leucócitos, principalmente os granulócitos, pode levar a estados de imunossupressão secundários à doença e, por consequência, a incidência de doenças bacterianas como pneumonia, sendo esta a principal causa de morte de pacientes. ${ }^{28}$ Dos 54 pacientes portadores de LVH, analisados por Kadivar et al. ${ }^{229}$, demonstrou-se a predominância de infecções bacterianas em 22 pacientes, causadas por bactérias da família Enterobacteriaceae, colonizando principalmente a pele, o trato urinário, respiratório e circulatório.

A associação de comorbidades como a presença de infecções bacterianas principalmente por Staphylocococcus aureus e Pseudomonas aeruginosa concorrem para o aumento da letalidade da doença. A condição de comorbidades é frequente em pacientes com LV. $^{128,161}$

Além disso, a desnutrição tem sido considerada com um dos principais fatores de risco para o desenvolvimento da forma sintomática da doença. ${ }^{225}$ 230-231 Diversos autores mencionam que a deficiência nutricional afeta particularmente a função fagocítica, produção de anticorpos, citocinas, afinidade de anticorpo com o antígeno e o sistema complemento, o que aumentaria o risco de morte. 
Contudo, há controvérsias na literatura, se a desnutrição é um fator predisponente por fazer parte do estado geral do paciente ou consequência da doença pela ação do parasito por exarcebar o quadro clínico do indíviduo com LV. ${ }^{232}$

Ao considerar 55 prontuários de pacientes como causa de morte por LV, Oliveira et $a l .^{221}$ concluiram que dentre as principais causas que contribuíram para o óbito, as infecções bacterianas foram as principais, ocorrendo em 27 (49\%) dos pacientes. Além de quadros de insuficiência respiratória 17 (30,9\%), insufiência renal aguda 11 (20\%) e hemorragia (digestiva, pulmonar epistaxe e gengivorragia) em 6 (10\%) foram considerados nos casos. Infecções fatais incluíram pneumonia e choque séptico.

\subsection{DIAGNÓSTICOS DA LVH}

Até a década de 1930, o diagnóstico humano e os inquéritos caninos eram realizados por meio dos exames diretos como a punção de fígado, de baço e o raspado da pele. Esses exames são seguros quanto à positividade dos casos, mas não eficazes para realizar uma cobertura total dos indivíduos positivos. ${ }^{138}$ A suspeita diagnóstica é baseada em dados epidemiológicos, achados clínicos e especialmente em exames laboratoriais. ${ }^{210}$

O diagnóstico clínico da LVH é realizado a partir de sinais e sintomas, como a febre baixa e recorrente, envolvimento linfático, hepatoesplenomegalia e esplenomegalia, combinados com a história de residência ou passagem em áreas endêmicas. ${ }^{13,212,233}$ Alguns exames complementares evidenciam em diferentes graus anemia, trombocitopenia, leucopenia, hipoalbunemia e hipergamaglobulinemia. ${ }^{29,117,128}$

A confirmação da doença requer a demonstração do parasito em esfregaço e cultura de tecido, principalmente medula óssea e o baço. Contudo, o método utiliza procedimentos invasivos, e a sensibilidade varia entre $70 \%$ para os aspirados de medula óssea a $90 \%$ dos aspirados do baço. Todavia, na cultura de parasitos, há um aumento na sensibilidade, acima de $80 \%$, mas pode retardar o diagnóstico em semanas. ${ }^{31,115,234}$ Por essa razão, testes diagnósticos menos invasivos e mais precisos têm sido desenvolvidos a fim de aprimorar o diagnóstico da LVH. ${ }^{210}$ 


\subsubsection{Teste Intradérmico de Montenegro (IDRM) e Suas Aplicações}

Com a finalidade de auxiliar o diagnóstico clinico da leishmaniose tegumentar, Montenegro, em 1926, introduziu em estudos clínicos um teste intradérmico com a suspensão de promastigotas mortas de L. braziliensis. A facilidade de execução, a alta especificidade, sensibilidade e o baixo custo, tornaram esse teste amplamente difundido e bastante utilizado como o principal exame de rotina, no Brasil e no Mundo. ${ }^{225,235}$

O teste consiste na inoculação, por via intradérmica, $0,1 \mathrm{~mL}$ de antígeno de Leishmania na face anterior do antebraço do indivíduo a ser examinado. Após um período de 48 a 72 horas é realizado uma leitura a partir do tamanho diâmetro do endurecimento no antebraço. A reação é considerada positiva se, na leitura feita 48 horas após aplicação, detectar-se enduração no local de mais de 5 milímetros de diâmetro, caracterizando indivíduos imunodeprimidos, sendo dessa forma, muito útil no diagnóstico da forma assintomática ou inaparente da LV em áreas endêmicas. ${ }^{234,236}$

A negatividade da IDRM se refere não apenas a indivíduos que não tiveram contato com o parasito, mas não apresentaram reatividade ao teste. São vistos como imunocompetentes acusando a fase ativa da doença. ${ }^{32,237}$

Bearman et al. ${ }^{287}$ mostraram a grande variabilidade entre os observadores existentes quando o tuberculínico é lido diretamente no braço do paciente, por palpação. Com os estudos de Bearmam, Sokal ${ }^{239}$ propôs a metodologia de demarcação da área endurada com uma caneta esferográfica, sugerindo assim a facilidade do teste por qualquer profissional treinado, reduzindo a variabilidade entre os observadores. Essa metodologia logo foi incorporada à IDRM.

Posteriormente, passou a se documentar a reação por meio de aposição umedecido com álcool sobre o contorno da enduração desenhando com a caneta esferográfica, no braço do paciente, produzindo um decalque do local da aplicação do teste. Esse papel decalcado funciona como registro permanente do resultado do IDRM, e o decalque do contorno da enduração também podem ser medidos. Contudo, Fagundes et al. $^{235}$ aventam que não há estudos disponíveis na literatura que comparando as medições in vivo no local da aplicação do teste e aqueles registrados no papel. ${ }^{239}$

O teste de Montenegro foi confirmado por Buss em $1929^{240}$ e outros autores com o número limitado de pacientes. Utilizando de soluções alcalinas fenoladas de promastigotas de L.brazilienses, Salles Gomes testou 120 pacientes, dos quais 25 estão confirmados com o teste parasitológico, encontrando, contudo, 117 (97,5\%) positivos respectivamente. As reações 
eram classificadas de 1 a 4 cruzes, com reações duvidosas até fortemente positivas e lidas de 48 a 72 horas após a aplicação.

Os dados de Salles Gomes ${ }^{240}$ foram confirmados por Pessoa \& Pestana ${ }^{243}$. Segundo os autores, a intensidade do IDRM associava-se com a lesão da mucosa e que permanecia a positividade da reação em indivíduos curados. A partir disso, concluíram que o IDRM constituiria uma ferramenta importante também no diagnóstico retrospectivo para leishmanioses e de grande utilidade em inquéritos epidemiológicos.

De um modo geral, considera-se a IDRM como altamente específica a LTA, apresentando sensibilidade em torno de 86 a $100 \%$ e especificidade de aproximadamente $100 \%$, fato que consagrou o teste como um das provas, mais usadas na confirmação da doença em sua fase ativa, no diagnóstico retrospectivo e em inquéritos epidemiológicos. ${ }^{235} \mathrm{Em}$ estudos prospectivos Marink et al., ${ }^{244}$ demonstraram a ocorrência da negativação do IDRM em indivíduos inicialmente positivos, cerca de cinco anos após o teste inicial. ${ }^{244}$

No diagnóstico da leishmaniose tegumentar, o resultado positivo do IDRM é encontrado fase ativa da doença. Contrariamente, na LV o IDRM tem outro comportamento, sendo negativa durante a fase ativa da doença e tornando-se positiva após semanas ou até anos de tratamento. Para essa forma clínica de Leishmaniose, o IDRM torna-se importante para estudos epidemiológicos, com o encontro de indivíduos positivos sem desenvolvimento da doença. ${ }^{32}$

A sintomologia da LVH é marcada por uma depressão na resposta imunológica mediada por células, pois os indivíduos não respondem aos testes de hipersensibilidade tardia com antígenos de Leishmania durante a fase ativa da doença. Em decorrência da ativação das células B, a LVH está associada a uma resposta ineficaz de células $\mathrm{T}$ que pode ser comprovada por testes cutâneos de Intradermoreação de Montenegro (IDRM). ${ }^{32}$

A utilidade do teste é demonstrada ainda em estudos que acompanham indivíduos curados de LV, bem como os inquéritos epidemiológicos para determinar a prevalência e a incidência de infecção assintomática e sem doença. A negatividade do teste, por exemplo, tem sido utilizada como critério de inclusão de indivíduos em estudos que visam caracterizar a resposta imune e a eficácia da imunização após utilização de vacinas contra a leishmaniose. $126,227$.

A reação é considerada positiva, quando há endurações com diâmetro superior a 5 $\mathrm{mm}$, caracterizando indivíduos imunodeprimidos, sendo dessa forma, muito útil no diagnóstico da forma assintomática ou inaparente da LV em áreas endêmicas. Em 
contrapartida, a negatividade da IDRM se refere não apenas a indivíduos que não tiveram contato com o parasito, mas não apresentaram reatividade ao teste. São vistos como imunocompetentes acusando a fase ativa da doença. ${ }^{32,237}$

\subsubsection{Testes parasitológicos}

O exame direto consiste na visualização das formas amastigotas e ou promastigotas do parasito em material obtido das lesões ou tecidos afetados. Consiste em um exame de primeira escolha. O teste histopatológico convencional com hematoxilina-eosina também é útil na detecção das formas amastigotas. Essas formas de vida do parasito podem ser visualizadas por meio de aspirado do baço, medula óssea, linfonodo e biópsia hepática. O material obtido é corado com corantes de rotina, tais como Giemsa, Wright e Panótico. ${ }^{152}$

Apesar de fornecerem a certeza da infecção, os testes parasitológicos são reconhecidos como métodos invasivos que requerem profissionais especializados a fim de evitar no procedimento a ocorrência de manifestações álgicas no local da coleta e hemorragia. $29,241,242$

Caracterizam-se por serem testes altamente específicos, mas de sensibilidade variável dependendo do tipo de tecido aspirado. A sensibilidade da pesquisa direta em lâmina varia 95 a $98 \%$ para o aspirado do baço; a medula óssea $60-80 \%$ e 50-60\% para os linfonodos, respectivamente. ${ }^{30,33,115}$

\subsubsection{Testes sorológicos}

Os testes sorológicos são favorecidos pela resposta imune celular que caracteriza a doença, cuja finalidade é a detecção de anticorpos específicos, anti-Leishmania. Em 1938, o teste de fixação de complemento (RFC) foi utilizado pela primeira vez como diagnóstico da LVH. $^{138}$

Atualmente é um dos testes disponibilizados no SUS para o diagnóstico da doença. Apesar da utilidade no diagnóstico, alguns estudos apresentam divergências acerca do teste, como a baixa especificidade, utilização de técnicas que demandam tempo, equipamentos (microscópio de imunofluorescência) e laboratoristas ${ }^{31 .}$ 
A técnica de imunofluorescência indireta (RIFI) foi utilizada a partir da década de 1960. É visto como um dos testes mais utilizados no Brasil. Na presença de dados clínicos e laboratoriais, um teste sorológico reagente, reforça o diagnóstico da LVH. ${ }^{13}$

Apresenta uma sensibilidade que varia em torno de 90 a $100 \%$ e especificidade aproximada de $78 \%$ a $92 \%$, dependendo da preparação antigênica e da espécie de Leishmania utilizada. Para Assis et $a l .{ }^{31}$ a especificidade desse teste prejudicada devido à presença de reações cruzadas com doenças causadas por outros tripanossomatídeos, como por exemplo, a doença de Chagas e a leishmaniose tegumentar americana (LTA).

O teste de ELISA é o mais utilizado para o imunodiagnóstico de LV. É um teste rápido, de fácil execução e leitura que permite a detecção de baixos título. ${ }^{31}$

O diagnóstico sorológico por hemaglutinação direta (DAT) caracteriza-se como testes mais simples e de baixo custo. Apresenta uma sensibilidade de $91 \%$ a $100 \%$ e tem sido validado em diversas áreas endêmicas. Para Boelaert ${ }^{245}$, apesar dessas vantagens, o teste apresenta dificuldade na padronização e controle do antígeno, além de não apresentar valor no prognóstico da doença.

Outras técnicas mais específicas e com maior sensibilidade fizeram surgir, a partir da década de 1970, variações das técnicas de ELISA (Ensaio Imuno-Enzimático) Dot-ELISA, fucose manose ligant-ELISA OU FML-ELISA, bovine mucin submaxillary - ELISA ou BSM-ELISA, fast-ELISA, micro-ELISA, entre outras. A técnica de Western blot é bastante preciso quando aplicado ao diagnóstico em casos de coinfecção HIV. No Brasil, os testes mais utilizados no diagnóstico de LV humana e canina são a RIFI e ELISA, sendo considerados testes de escolha para inquéritos populacionais. ${ }^{8,152}$

A baixa especificidade é a desvantagem comum aos métodos que utilizam antígenos não purificados, causada pela reatividade cruzada e persistência de anticorpos após cura. Em função disso, antígenos purificados sintéticos e recombinantes têm sido testados como ferramentas para uma validação satisfatória do diagnóstico. ${ }^{31}$

A proteína rK 39, é identificada como uma alternativa para o diagnóstico da LV. O antígeno rK 39 é membro da família das cinesinas constituída por uma sequência de 298 aminoácidos e com 39 Kilodaltons (KDa), clonada da região quinase de L. Chagasi do complexo L. donovani específico. A detecção de anticorpos IgG anti rK 39 tem se mostrado bastante sensível e específico para LV. ${ }^{242,246}$

A utilização da rk 39 baseados em métodos ELISA apresentou uma sensibilidade de 93 a $99 \%$ e uma especificidade de 93 a 100\%. É descrito também a utilização dessa proteína 
em plataformas imunocromotográficas, que permitem execução simples e interpretação visual das reações, que apresentam valores de sensibilidade e especificidade que variam de 67 a $100 \%$ e de $59 \%$ a $100 \%$, respectivamente. A avaliação desses testes apresentam resultados variáveis de acordo com a área geográfica do estudo, produto e da metodologia. ${ }^{247}$

O DiaMed IT-Leish, produzido pela DiaMed Latino América S.A., (Lagoa Santa, Minas Gerais e Brasil), é um teste imunocromatográfico cuja finalidade é a detecção rápida de anticorpos contra Leishmania ssp. Em uma membrana de nitrocelulose são absorvidos o antígenos rK 39, formando a linha teste, e o antígeno anti-IgG humano, contribuindo o antígeno a linha controle. O teste é considerado positivo quando for possível a visualização das duas linhas, teste e controle, e negativo quando for possível a visualização de apenas uma das linhas, o controle.

No Brasil, o IT-Leish foi avaliado pelo Ministério da Saúde em estudo multicêntrico, no qual foram incluídos 213 casos e 119 controles. O teste apresentou uma sensibilidade de $90 \%$ e especificidade de $97 \%$. Com base nesses resultados, Assis et al. $^{31}$ recomendaram a utilização do teste no diagnóstico da LV. Desde então, os testes rápidos foram avaliados quanto a sua sensibilidade e especificidade em várias regiões endêmicas. ${ }^{247,248}$

Além do IT-LEISH, outros testes rápidos são reconhecidos para o diagnóstico da LV, como o Kala-Azar detect e o teste de imunoflourescência- IF-LH. O Kala-Azar detect é um teste rápido de imunocromatografia fabricado pela InBios International, Seattle, WA, USA, destinado a determinação qualitativa no soro, contra o antígeno recombinante K39 L.L (Chagasi $^{242}$. Um estudo comparativo entre esses testes revelaram uma sensibilidade e especificidade de $88,1 \%$ e $88,6 \% ; 93,3 \%$ e $88,6 \%$, respectivamente, e $90,6 \%, 96,5 \%$ e $80 \%$, respectivamente. ${ }^{248}$

Análises realizadas com rK 39 com o soro de 128 pacientes com LV confirmam a utilidade do teste rápido para o diagnóstico, nos quais foram demonstrados uma especificidade de $100 \%$ e uma sensibilidade de $90 \% .^{242}$

Ainda segundo os autores, o desenvolvimento de testes rápidos com a rK 39 representa um avanço no diagnóstico da LVH. Um desempenho adequado do teste combinado com as suas facilidades de aplicação, proporciona um maior acesso a serviços de diagnósticos da doença principalmente em áreas endêmicas. Destacam ainda o uso dos testes rápidos nas unidades de atenção primária à saúde, haja vista a sua simplicidade, baixo custo e rapidez no resultado. $^{248}$ 
Recentemente novas técnicas têm sido amplamente avaliadas para o diagnóstico sorológico como, por exemplo, a loop-mediated isothermal amplification (LAMP), Nucleic Acid Sequence-Based Assay (NASBA) e Latex Agglunation Test (KArex). ${ }^{33}$

\subsubsection{Diagnóstico Molecular}

A partir da década de 8190, foram desenvolvidas diversas técnicas de biologia molecular para detectar e identificar parasitos do gênero Leishmania, sem a necessidade de isolar o parasito em uma cultura ${ }^{152 .}$

A reação em cadeia da polimerase (PCR) é uma técnica altamente sensível e específica, e por detectar o DNA ou RNA do parasito em diagnóstico humano, canino e do flebotomíneos. Dentre as ferramentas moleculares mais empregadas está a PCR, na identificação de gênero e espécie, bem em estudos sob diversidade genética e evolução de Leishmania. $^{241,249-250}$

O DNA do cinetoplasto, o kDNA, tem sido utilizado como ferramenta no diagnóstico pela PCR, devido a capacidade de identificar pequenas quantidades de DNA do parasito em materiais biológicos, o que se deve à presença de minicírculos. O alto grau da kDNA juntamente com estruturas conservadas favorecem sua utilização para fins taxonômicos e genéticos. $^{250}$

Para a técnica de PCR, iniciadores como RV1 e RV2, são aplicados com sucesso na identificação de Leishmania chagasi em humano. Lima-Junior ${ }^{250}$ avaliaram, por PCR, 39 isolados de sangue medular de humanos, dos quais 37 foram positivos a L. chagasi para esses iniciadores. Contribuindo, dessa forma, para a identificação da espécie em áreas endêmicas de LV no estado do Mato Grosso do Sul bem como no processo de diagnóstico da parasitose. Esses achados também corroboram a eficiência da técnica em outros estudos descritos na literatura. ${ }^{251-252}$

Paiva et al. ${ }^{253}$, utilizando PCR, observaram que, em Minas Gerais, $98 \%$ dos casos humanos estudados estavam infectados com espécies do gênero do subgênero L. Vianna, provavelmente L. brazilienses.

Desde o primeiro uso da PCR para detecção de Leishmania, vários métodos moleculares com base na PCR foram elucidados. ${ }^{254,250}$

O método de PCR em tempo real, técnica desenvolvida por Christian A. Heid em 1996, também é utilizado para o diagnóstico da LV. A finalidade dessa técnica consiste no 
monitoramento contínuo da amplificação do DNA do parasito, o que permite a quantificação parasitária em diferentes amostras. ${ }^{30,138}$

A eletroforese por enzimas, considerada padrão ouro para o diagnóstico, é utilizada para caracterização de cepas, principalmente de Leishmanias circulantes no Brasil. As análises de isoenzimas permitem a identificação de similaridades e diferenças entre os organismos possibilitando assim o entendimento acerca das relações genéticas empregadas na identificação e classificação taxonômica de diversos parasitos. Entretanto, as principais limitações se devem a necessidade de cultivo e isolamento de parasitos, o que impede a caracterização de algumas amostras. ${ }^{250,255}$

Dentre as aslternativas para o diagnóstico molecular estão a identificação de anticorpos monoclonais, técnicas variadas de PCR, PCR-RLP (polimorfismo no comprimento de fragmento de restrição), RAPD (polimorfismo de DNA amplificado ao acaso) e PCR multiplex.

Em relação a demais ferramentas moleculares, a PCR convencional é a que apresenta elevada sensibilidade, reprodutibilidade e especificidade. Um estudo conduzido na Índia com casos de LV demonstrou por meio da técnica de PCR uma sensibilidade de $90 \%$ e especificidade de $100 \% .^{223}$

\subsection{TRATAMENTO}

Por mais de sessenta anos, o tratamento da LV é realizado com antimoniais pentavalentes: antimoniato de N-metil glucamina, Glucantime ${ }^{\circledR}$, e estiboglucanato de sódio, Pentostan $^{\circledR}$, que são medicamentos de primeira escolha. Caracterizam-se por serem tóxicos e parcialmente efetivos. Na LV, são administrados em esquemas prolongados. ${ }^{152,256}$

Este fármaco age sob os mecanismos bioenergéticos das formas amastigotas do parasito, por meio da glicólise e $\beta$-oxidação, que ocorrem em organelas denominadas glicossomas. Outro mecanismo de ação discutido na literatura é o de ligação com sítios sulfidrílicos, deflagrando a morte destes protozoários. ${ }^{223}$

De um modo geral, os antimoniais pentavalentes têm representado a base de tratamento da Leishmanioses nas últimas décadas, com índice de curas de 60 a 90\%. A necessidade de administração parenteral e a toxicidade da droga, principalmente em crianças e cardiopatas e nefropatas dificultam o seu emprego. Embora raro, existem relatos de morte súbita desencadeada por antimoniais pentavalentes. ${ }^{256-257}$ 
Um dos principais efeitos colaterais do Glucantime é a sua ação no aparelho cardiovascular, sendo desaconselhável sua utilização durante os dois primeiros trimestre da gravidez. $^{8,115,152 .}$

Empregada primeira vez por Kit \& McDonald ,em 1940, no tratamento da LV, é a pentamidina. Refere-se a dois sais de pentamidina, disponível nos EUA e Europa e o mesilato de pentamidina, disponível apenas na Europa. Diferem quanto à dose e diabetogênico. Quanto ao mecanismo de ação, age sob o transporte de aminoácidos, compete com poliaminas pelos aminoácidos e pode ligar-se preferencialmente ao DNA do cinetoplasto. ${ }^{256,258}$

A anfotericina B é segunda opção da desoxicolato e as formulações lipossomais (Anfotericina B-lipossomal e Anfotericina B-dispersão coloidal), e as pentamidinas (sulfato e mesilato) e os imunomoduladores (interferon gama e GM-CSF). Esse fármaco é a droga leishmanicida mais potente disponível comercialmente, atuando nas formas promastigota e amastigota do parasito, tanto in vitro quanto in vivo. ${ }^{13,223}$

O mecanismo de ação se dá por meio da interação especificamente com o esteres (ergosterol, esteroide ou episterol) presentes na membrana das leishmanias, alterando a sua permeabilidade e morte do parasito. ${ }^{223}$

Apesar da reconhecida eficácia cono tratamento, a anfotericina B, apresenta alta toxicidade. Os efeitos colaterais são inúmeros e frequentes, todos dose-dependentes, sendo altamente tóxica para as células do endotélio vascular, causando flebite,considerada um parafeito comum. É visto que duração a infusão, poderá ocorrer cefaleia, calafrios, astenia, dores musculares e articulares, vômitos e hipertensão. ${ }^{13}$

O desenvolvimento da anfotericina B encapsulada em lipossomas (AmBisome) demonstrou bons resultados na Índia e Sudão. Essa forma lipossomal age especificamente sobre as células-alvo (macrófagos), sendo incorporada ao meio intracelular, e assim, reduzindo os efeitos colaterais com o maior índice de eficácia terapêutica, inclusive em pacientes sem respostas ao antimonial. ${ }^{256-257}$

$\mathrm{Na}$ Europa, é descrito como o medicamento de primeira linha por Murray. ${ }^{259}$ Apesar de sua efetividade, a resistência da Leishmania contra a anfotericina B alcança $65 \%$ dos casos tratados na Índia. Além disso, há ocorrência de eventos adversos graves.

A anfotericina B é a droga de escolha para o tratamento da LVH em gestantes, em razão da toxicidade a possibilidade de efeitos teratogênicos dos antimonais pentavalentes. É recomendado para pacientes que tenham contraindicações ou que manifestam toxicidade ou refratariedade relacionada ao uso dos antimoniais pentavalentes. ${ }^{90,105,152}$ 
O desenvolvimento da anfotericina B encapsulada em lipossomas (AmBisome) demonstrou bons resultados na Índia e Sudão. Nos Estados Unidos e no Sul da Europa é descrito como o medicamento de primeira linha. ${ }^{259}$ Apesar de sua efetividade, a resistência da Leishmania contra a anfotericina B alcança $65 \%$ dos casos tratados na Índia.

A miltelfosina, também conhecida como hexadecylphocholina, foi à primeira medicação oral descrita para a LVH. Refere-se a um derivado de fosfolipídio, de administração oral. Na Índia, esse fármaco tem sido amplamente utilizado no Programa de eliminação da LV no qual tem se mostrado eficaz no tratamento da doença. ${ }^{45,115}$

Comparada a pentamidina, a qual apresenta uma alta toxicidade e dificuldades na administração, o tratamento com a miltefosina, é visto como eficaz devido a sua meia vida o que permite uma maior resistência do fármaco. ${ }^{45} \mathrm{~A}$ sitamequina é uma alternativa farmacológica testada em estudos na Índia, Kenya e Brasil demonstrando uma taxa de cura de $27 \%$ a $87 \%$. No entanto, é sugerida uma a combinação terapêutica com os fármacos a fim de aumentar a eficácia no tratamento, amenizar efeitos colaterais e diminuir os custos com o tratamento. ${ }^{115}$

O tratamento convencional da LV com fármacos envolvem muitos impasses, relacionados à via de administração do fármaco, longo período de tratamento, severa toxicidade (nefro e cardio toxicidade entre outras), alto custo de tratamento, resistência e determinadas respostas fisiológicas dos pacientes ao tratamento. ${ }^{13,223 .}$

O desenvolvimento de vacinas para o tratamento da LVH é visto por Jain \& Jain ${ }^{260}$ e por Ready ${ }^{45}$ como a alternativa mais eficaz para o controle. Além disso, o desenho de novos quimioterápicos com pouco efeito adverso é indicado como alternativas que buscam fornecer um completo tratamento a doença.

De acordo com o Ministério da Saúde, as recomendações da escolha do medicamento da LV deve levar em consideração o perfil de toxicidade das drogas. ${ }^{39}$ Alguns estudos sugerem a combinação terapêutica com os fármacos indicados para o tratamento a fim de aumentar a eficácia no tratamento, possíveis mutações, amenizar efeitos colaterais e diminuir os custos com o tratamento. Ready ${ }^{45}$ apresenta alguns testes (Fase III) de combinações farmacológicas. Na Índia é testada a Ambisome, a fórmula lipossomal da Anfoterecina B, miltefosina, paromomycina. E no Sudão, o Stiboglucanato de sódio com paromicina no Sudão. ${ }^{115}$ 


\subsection{AS ESTRATÉgIAS DE CONTROLE DA LV E AS POLÍTICAS DE SAÚDE}

Historicamente, a campanha contra a Leishmaniose visceral (CCL) foi criada em 1953, tendo em vista o aumento no número de casos da doença no país. Durante os anos 60, essas campanhas foram interrompidas, sendo novamente retomado nos anos de 1980, cujo período foi marcado aumento de casos, principalmente na região Nordeste do País. 9,13, 146, 261, 162

As estratégias de controle recomendadas pelo Programa Nacional de Controle da LV são direcionadas nos seguintes eixos de atuação: a detecção precoce, tratamento de casos humanos, investigação sorológica de cães domésticos, controle vetorial e também programas de educação em saúde. ${ }^{13}$

Considerando o fato da LVH ainda apresentar uma situação epidemiológica preocupante, marcada por uma alta letalidade, muitos autores discutem a eficácia dessas medidas, refletindo a necessidade de novos estudos a fim de avaliar a eficácia e efetividade das medidas de controle, sobretudo em áreas prioritárias. 9, 37, 38, 51,

Teoricamente, tanto o controle vetorial quanto a eliminação de cães, podem ser consideradas medidas efetivas. O uso de inseticidas, por exemplo, diminui o tempo médio de vida do vetor, um dos principais determinantes da transmissão.

De um modo geral, no Brasil, a prática de controle que envolve essas estratégias não apresentou êxito, principalmente devido a questões relacionadas a problemas orçamentários e escassez de recursos humanos. ${ }^{23,37,152}$

As medidas de controle centradas na eliminação de cães infectantes permite a diminuição da expectativa de vida canina. No tocante, são discutidas a eutanásia de cães soropositivos e a impregnação de coleira com deltametrina $4 \%$ Esta, por sua vez, mostrou resultados satisfatórios em laboratório, com redução das taxas de alimentação sanguínea e efeito letal para as diferentes espécies de flebotomíneos testados em vários países. ${ }^{261-262}$

Os primeiros trabalhos de campo acerca dessa questão foram conduzidos no sudeste da Itália onde vetor é o Phlebotomus perniciosus. Com a finalidade de avaliar o impacto do uso dessas coleiras impregnadas com deltrametrina em cães, verificou-se uma proteção de $86 \%$ nos cães. ${ }^{263}$ No Irã, essa medida de controle também foi avaliada, a qual se verificou uma redução da incidência em cães com L. infantum (64\%), e em humanos, (crianças) um decréscimo de $43 \% .^{264}$

No Brasil, alguns autores concluíram que a utilização das coleiras impregnadas é mais efetiva para prevenir a transmissão, como uma forma de proteção individual dos cães 
contra a picada de flebotomíneos, quando comparada à eutanásia de cães soropositivos, por exemplo. Contudo, o Ministério da Saúde ${ }^{13}$ conclui que a adoção dessas medidas como programas de saúde pública, a fim de interromper o ciclo de transmissão doméstico, é necessária a implementação de estudos longitudinais que demonstrem sua efetividade como medida de controle. ${ }^{265}$

Do ponto de vista social, as ações de vigilância são as mais polêmicas, tendo em vista as ações de eutanásia de cães infectados e a contra indicação de tratamento canino como ferramenta de bloqueio na transmissão. ${ }^{10,13,37,38,152,266}$

O processo de urbanização da $\mathrm{LV}$ em áreas urbanas e a expansão territorial da doença conduziu o MS a reavaliar as medidas de controle adotadas, haja vista que elas não são capazes de eliminar os casos em algumas regiões endêmicas. Essas medidas têm se mostrado insuficientes para conter o avanço da doença e a ocorrências de novas epidemias e também o aparecimento de casos novos em áreas indenes ${ }^{152}$

A ineficácia das medidas de controle está centrada sob o ponto de vista operacional, quando aplicadas ao controle de vetores, reservatórios (cão) domésticos e também a distribuição de tratamentos. ${ }^{267-268}$

Sob o ponto de vista dos autores, Almeida et al. ${ }^{267}$ e Costa et al. ${ }^{267}$ a falência das medidas de controle estão centradas na baixa eficiência de alguns testes sorológicos para detectar a infecção em cães e na eliminação do cão infectado. Segundo os autores, isso permite a persistência da forma assintomática da doença e o convívio dos cães infectados com humanos.

No tocante ao controle vetorial, são discutidas questões como alto custo na utilização de inseticidas intra e peridomiciliar e os associados com ao limitado conhecimento ecológico do inseto vetor e fatores que favorecem a manutenção do ciclo biológico do parasito em determinadas regiões endêmicas. Todavia, o autor sugere uma identificação de áreas de risco a LV associadas às medidas de controle, e dessa forma, aumentaria sua eficácia e a otimização dos custos operacionais. ${ }^{9}$

O mapeamento de risco nas áreas afetadas por LV permite um acompanhamento e o controle em áreas endêmicas. ${ }^{157}$ Por outro lado, estudos baseados em modelos matemáticos apresentam um monitoramento para o entendimento da dinâmica da transmissão da LV. ${ }^{9}$

A modelagem matemática tem sido utilizada em alguns estudos sobre Leishmanioses a fim de compreender a dinâmica de transmissão dessas infecções. Para LVC, um modelo proposto por Haibeder, ${ }^{270}$ discute a possibilidade na natureza existir dois cães susceptíveis: 
Um tipo-A ,que ao se infectar permanece em um período de latência assintomático, esses cães são positivos aos testes sorológicos e não infectantes. Após esse período, se tornam sintomáticos e infectantes, a manifestação da doença ocasiona uma maior taxa de mortalidade desses cães. Em relação ao tipo-B, seriam cães que após o período de latência desenvolveriam pouco ou nenhum sintoma, podendo perder a positividade dos testes sorológicos, e nunca seriam capazes de transmitir o parasito ao vetor (não infectantes).

Palatnik de Sousa, ${ }^{9}$ utilizando o modelo base proposto por Dye ${ }^{271}$ observou a influencia da sensibilidade de testes diagnósticos na eficácia da eliminação como estratégia de controle.

A falta de efetividade dessas estratégias de controle está na ausência de um programa de vigilância permanente com a utilização extensiva de recursos humanos e financeiros. São apresentadas por Werneck et al. ${ }^{10}$ alguns fatores que contribuem para a não eliminação do cão infectante e consequentemente o aumento da prevalência da LV em cães. São eles: os cães que nem parecem doentes nos primeiros estágios da infecção, os animais assintomáticos que podem ser igualmente infectantes para os vetores e por fim, os cães eliminados quase que imediatamente substituídos por uma nova população passível de adquirir a infecção rapidamente em áreas altamente endêmicas. O autor destaca ainda a necessidade do delineamento de estudos brasileiros com o objetivo de avaliar conjuntamente a efetividade do controle vetorial, eliminação canina e redução da infecção humana.

\subsection{A LV NO ÂMBITO DA ATENÇÃO PRIMÁRIA À SAUDE}

Um dos traços fundamentais da atenção primária à saúde, em qualquer de seus modelos de organizações de ações, é a perspectiva da integralidade. Esse princípio é compreendido como um atendimento integral direcionado as atividades preventivas e de promoção à saúde. Uma das acepções de integralidade pode ser tomada como a articulação entre promoção, prevenção e recuperação que são instituídas para a realização do cuidado em saúde por meio de ações que se interpenetram. ${ }^{272,273}$

O eixo de estratégias contra as doenças endêmicas depende basicamente da disponibilidade de recursos econômicos e, necessariamente, do conhecimento das competências e atitudes da população diante dos problemas mórbidos, relevantes para a aceitação e participação efetiva nas ações profiláticas. Luis et al. ${ }^{274}$ citam a educação como controle cultural para a LVH, por tornar participantes diversas camadas da população e por 
democratizar atitudes capazes de beneficiar as práticas de controle. Foi realizado em Belo Horizonte, um estudo em que se avaliou o nível de conhecimento e de atitudes preventivas da população a respeito da LV, segundo os autores, a precariedade de informação sob a doença aponta para a necessidade de realização de práticas educativas em diferentes frentes, que podem contar com médicos, veterinários, durante consultas, professores e agentes de saúde em palestras e durante visitas domiciliares. ${ }^{275}$

\subsection{JUDICIALIZAÇÃO DA SAÚDE}

A judicialização da saúde é um fenômeno que expressa reivindicações e modos de atuação legítimos de cidadãos e instituições para a garantia e promoção do direito da cidadania amplamente firmados em leis nacionais e internacionais. Envolve aspectos políticos, sociais, éticos e sanitários. Trata-se da consolidação da jurisprudência e da intervenção do poder judiciário na gestão de saúde, principalmente no âmbito da assistência farmacêutica. Estudos apontam que grande parte da demanda se concentra nos processos judiciais individuais de cidadãos reivindicando por uma assistência farmacêutica. Um levantamento realizado no ano de 2006 demonstrou um gasto de 65 milhões em cumprimento a ações judiciais pela garantia de medicamentos a 3.600 pessoas. ${ }^{276-277}$

O fenômeno da judicialização ,no Brasil, ganhou forças na década de 1990, a partir de iniciativas de algumas organizações não governamentais (ONGs), pela responsabilização dos entes federativos no seu comprimento imediato de dever estatal no sentido de avançar as políticas públicas de saúde voltadas a assistência às pessoas com HIV/AIDS, sob a perspectiva de garantir acesso universal aos medicamentos retrovirais. A partir de então, esse mecanismo mobilizou outros grupos sociais e a população em geral a utilizar desse mecanismo a fim de garantir a ampliação das políticas públicas de saúde e a garantia de seus direitos preconizados em lei. A judicialização vem crescendo de forma vertiginosa e a cada ano há incremento das ações contra o Poder Público. ${ }^{276,278}$

Em meados de 2002, muitas discussões foram levantadas com referência ao controle da leishmaniose visceral canina (reservatórios). Das ações de vigilância e controle da LV, as relacionadas ao reservatório doméstico (cão) são consideradas, do ponto de vista social, as mais polêmicas, devido à indicação da eutanásia de cães infectados e a contraindicação do

tratamento canino como ferramenta para bloqueio da transmissão vetorial. ${ }^{279-280}$ 
A judicialização das ações de vigilância em saúde retira da esfera técnica as decisões de controle da doença, interferindo nas estratégias de controle da LV. Sob esse ponto de vista, a atuação do Ministério Público tem centrada no Termo de ajustamento de conduta-TAC em capitais que apresentam um amplo espectro epidemiológico da doença com a finalidade de direcionar as formas de eliminação dos reservatórios. (Lane et al., 2013). 


\section{OBJETIVOS}

\subsection{OBJETIVO GERAL}

Contribuir para o entendimento de aspectos determinantes da leishmaniose visceral como problema de saúde pública no Brasil no âmbito da situação epidemiológica e das medidas de controle da doença.

\subsection{OBJETIVOS ESPECÍFICOS}

- Descrever as ações legais existentes contra a eutanásia de animais infectados em capitais brasileiras com endemias de LV.

- Avaliar o conhecimento de profissionais de saúde da atenção primária de um território endêmico acerca das medidas de controle da LV.

- Analisar a evolução clínica de pacientes assintomáticos residentes em território endêmico para LV assintomáticos comprovados por meio de teste de Montenegro.

- Descrever a evolução epidemiológica da LV no Brasil, levando-se em consideração fenômenos demográficos e de desenvolvimento científico. 


\section{METODOLOGIA}

\subsection{ESTUDO 1: JUDICIALIZAÇÃO DAS AÇÕES DE VIGILÂNCIA EM SAÚDE: O CASO DA LEISHMANIOSE VISCERAL}

\subsubsection{Delineamento do estudo}

Foi realizado um estudo descritivo e retrospectivo dos Termos de Ajustamento de Conduta-TACs assinados ou propostos aos gestores públicos de saúde que continham orientações e mudanças nas ações de vigilância em saúde e controle da LV entre os anos de 2005-2009, em quatro capitais brasileiras.

\subsubsection{Seleção dos Munícipios}

Foram selecionadas as capitais que apresentavam os seguintes critérios de inclusão:

- Notificação de casos autóctones de LV;

- Inclusão na lista dos Municípios prioritários do Programa Nacional de leishmaniose visceral no Ministério da Saúde;

- Ter classificação de transmissão intensa de LV;

- Apresentar o TAC impetrando contra o gestor, com as solicitações direcionadas ao Programa de Controle Nacional de vigilância e controle da LV.

\subsubsection{Dados Epidemiológicos}

As informações sobre a epidemiologia da LV no Brasil foram extraídas do Sistema Nacional de Agravos de Notificação-SINAN.

\subsubsection{Dados Econômicos e Demográficos}

Os dados populacionais foram obtidos do censo de 2010 realizado pelo Instituto Brasileiro de Geografia e Estatística. Os dados foram inseridos em planilha do Excel 2010 
para Windows e foram realizadas análises estatísticas por meio de medidas de tendência central (média) e construídos indicadores de incidência, mortalidade e letalidade.

As informações sobre indicadores de desenvolvimento humano municipal e nacional foram extraídas do sítio na internet do Programa das Nacões Unidas para o DesenvolvimentoPNUD, e os dados sobre Produto Interno Bruto dos municípios e do Brasil das publicações do IBGE; Contas Nacionais e da Sinopse do Censo de 2010.

\subsubsection{Questões éticas}

Este estudo foi conduzido de acordo com as determinações legais sobre ética em pesquisa vigentes no Brasil e foi dispensado de avaliação por um Comitê de ética em Pesquisa por utilizar dados de domínio público.

\subsection{ESTUDO 2: A INSERÇÃO DA LEISHMANIOSE VISCERAL HUMANA NO ÂMBITO DA ATENÇÃO PRIMÁRIA DE SAÚDE}

\subsubsection{Delineamento do estudo}

Trata-se de uma pesquisa descritiva exploratória e quantitativa, aplicando-se um questionário semiestruturado aos profissionais de saúde lotados na atenção básica das regiões de Sobradinho I e II e Fercal, entre novembro e dezembro de 2014.

\subsection{2 Área de Estudo}

A assistência da atenção básica de Sobradinho I é composta por cinco Unidades Básicas de Saúde (UBS): Águia, Arara, Bem-te-vi, Beija-Flor, João Barro e Sabiá; uma Clínica da Família de Nova Colina e as equipes da ESF: Nova Colina, Nova Dignéia, Córrego do Arrozal, Rota do Cavalo, Lara e Uberaba.

Em Sobradinho II, há as ESF's: Buritizinho, Serra Azul e Morada da Serra; as UBS’s: Vale dos Pinheiros, Vale das Acácias, e uma Clínica da Família, composta por uma ESF (Bem-me-quer).

A Fercal é formada por 13 comunidades, das quais seis são rurais (Boa Vista, Catingueiro, Córrego de Ouro, Engenho Velho, Ribeirão-Pedreira) e as demais são urbanas. É 
vista como uma das áreas mais pobres do DF e se insere na Área de Proteção Ambiental (APA) de Contagem. O núcleo populacional se desenvolveu a partir da instalação de duas fábricas de cimento na década de 1980, causando a ocupação irregular do solo com consequente desequilíbrio ambiental. Nesta região administrativa há duas UBS's: Queima Lençol e Alto Belo Vista, e duas ESF's: Engenho Velho e Catingueiro.

\subsubsection{Participantes}

O critério de seleção dos profissionais de saúde (enfermeiros e médicos das especialidades de pediatria, clínica médica e médicos da família) considerou a atuação direta em atividades assistenciais nas UBS's, constatando-se 41 profissionais nessas condições, dos quais 23 concordaram em participar da pesquisa.

\subsubsection{Procedimentos}

Os questionários foram aplicados a 23 profissionais de saúde das regionais de Sobradinho I e II e da Fercal, sendo dez enfermeiros e os demais profissionais médicos, distribuídos nas especialidades: pediatria (dois), clínica médica (sete) e médicos da família (quatro) (vide anexo).

Os dados dos questionários foram inseridos em uma planilha e analisados por meio de ferramentas de estatística descritiva. Cabe salientar que as respostas não respondidas foram classificadas como ignoradas.

\subsubsection{Questões éticas}

O estudo obedeceu às normas de pesquisas envolvendo seres humanos, com sigilo de informantes, termos de consentimento de todos participantes e aprovação do comitê de ética em pesquisa da fundação de ensino e pesquisa em Ciências da Saúde-FEPECS, Brasília/DF, (parecer 820.097). 


\subsection{ESTUDO 3: EVOLUÇÃO DE CASOS ASSINTOMÁTICOS EM UMA ÁREA ENDÊMICA A LVH NO DISTRITO FEDERAL, BRASÍLIA- DF}

\subsubsection{Delineamento do estudo}

Foi realizado um estudo de série de casos entre os anos de 2011 e 2014, a partir de sujeitos que se apresentaram com IDRM positiva em inquérito realizado em população de área endêmica do Distrito Federal no ano de 2007.

\subsection{2 Área de estudo}

O estudo foi conduzido na região da Fercal. Esta área e composta por treze comunidades, das quais, quatro apresentam características tipicamente rurais com fazendas e ranchos e pouco habitantes (Boa Vista, Catingueiro, Córrego de Ouro, Ribeirão-Pedreira) e as demais são urbanas com a distribuição casas próximas a florestas de savana (Bananal, Curvas, Engenho Velho, Fercal Leste e Queima Lençol), figura 10.

Figura 10. Localização das regiões de Sobradinho I e II e a região da Fercal, com a descrição das 13 comunidades.
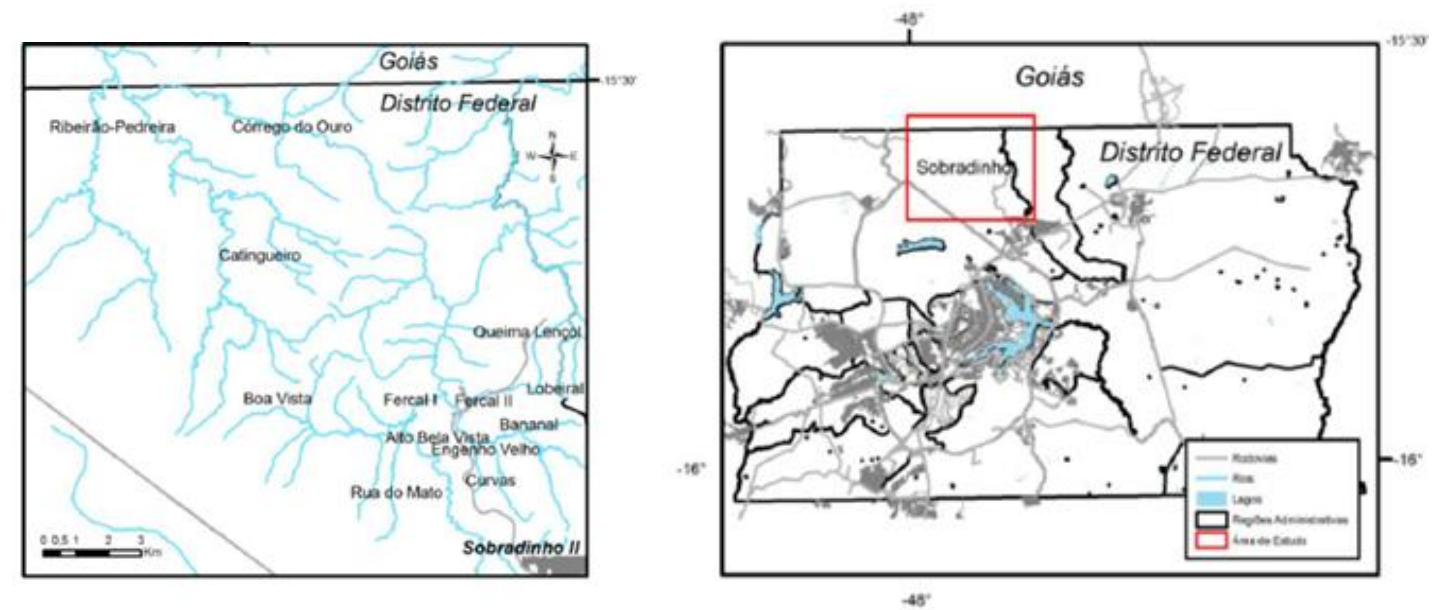

Fonte: Codeplan/DF; Adaptado por Carranza-Tamayo et al. ${ }^{157}$ 


\subsubsection{Procedimentos}

Foi realizado um inquérito populacional no ano de 2007 que envolveu 700 participantes desta região com a finalidade de se estabelecer a prevalência da LV. Na ocasião foram detectados 233 indivíduos com IDRM positiva.

\subsubsection{Visitas domicilares:}

Entre 2011 a 2014, foram realizadas visitas domiciliares às comunidades da Fercal juntamente com os agentes comunitários de saúde (ACS) que dão a cobertura de assistência básica no local, a fim de identificar os pacientes com o teste de IDRM positiva, sendo encontrados 120 destes indivíduos.

\subsubsection{Instrumento de coleta e Variáveis}

Os participantes da pesquisa foram convidados a uma entrevista pessoal, a qual foi conduzida por meio de um questionário semiestruturado com questões constituídas por: características individuais; socioeconômicas; aspectos gerais da comunidade, tópicos acerca da LV, condições socioeconômicas, saneamento básico, disposição do lixo e provisão da água tópicos acerca da LVH: (conhecimento sob a doença, forma de transmissão, sintomologia (sinais e sintomas da doença), e por fim a adoção de medidas de controle doença pelas autoridades de saúde (medidas de controle adotadas na comunidade) e acompanhamento dos indivíduos assintomáticos (IDRM positivos) pelas unidades básicas de saúde a fim de identificar o aparecimento de indivíduos que evoluíram para a forma clínica sintomática da doença (vide anexo).

Adicionalmente, foi feita uma correspondência manual entre os casos de LVH notificados para o Sistema Nacional de Agravos de Notificação (SINAN) do DF e os indivíduos que com a IDRM positiva em 2007 no intuito de se detectar a evolução para a doença entre os indivíduos assintomáticos. 


\subsubsection{Análise dos dados}

Foi criada uma base de dados no programa SPSS 19.0 (IBM statistics) e as variáveis foram analisadas por meio de uma estatística descritiva.

\subsubsection{Aspectos éticos}

O estudo obedeceu às normas de pesquisas envolvendo seres humanos, com sigilo de informantes, termos de consentimento de todos participantes e aprovação do comitê de ética em pesquisa da fundação de ensino e pesquisa em Ciências da Saúde-FEPECS, Brasília/DF, (parecer 820.097).

\subsection{ESTUDO 4: Evolução Epidemiológica da Leishmaniose Visceral em períodos de tempo com base nas alterações demográficas e as realizações científicas do Brasil.}

\subsubsection{Delineamento do estudo}

Foi realizada uma revisão narrativa de artigos publicados acerca da LV no Brasil desde a sua primeira descrição em 1937.

\subsubsection{Dados demográficos}

As informações demográficas foram obtidas no sítio na internet do Instituto Brasileiro de Geografia e Estatística-IBGE, principalmente da seção séries estatísticas e históricas (http://www.serieestatisticas.ibge.gov.br).

\subsubsection{Procedimento}

No intuito de explicar o processo de urbanização da leishmaniose, foram criados períodos em que houvesse consistência histórica entre os conhecimentos alcançados acerca da LV e as características demográficas do Brasil, principalmente considerando-se os grandes movimentos migratórios ocorridos no Brasil em decorrência de fatos políticos e econômicos. 


\section{RESULTADOS}

Esta tese será apresentada em forma de manuscritos e consiste em quatro artigos que descrevem: as ações de judicialização da saúde direcionados aos casos caninos de LV, como vistas aos pilares de controle da doença; a inserção da atenção primária à saúde nos casos de LVH; a evolução de casos assintomáticos de LVH em uma área endêmica do Distrito FederalDF; e, por fim, o último trabalho se propõe a uma narrativa histórica dos casos de LVH no Brasil que a consolidou como endemia urbana.

Artigo 1: Judicialização das Ações de Vigilância em Saúde: o caso da Leishmaniose Visceral.

Artigo 2: Inserção da Leishmaniose Visceral Humana no âmbito da atenção primária de saúde.

Artigo 3: Evolução de casos assintomáticos em uma área endêmica a LVH no Distrito Federal, Brasília-DF.

Artigo 4: Visceral Leishmaniasis epidemiologic evolution in timeframes based on demographic changes and scientific achievements in Brazil. 
ARTIGO 1: Judicialização das Ações de Vigilância em Saúde: o caso da Leishmaniose Visceral

Artigo publicado Revista Tempus-Acta de Saúde Coletiva-Universidade de Brasília-UNB. 


\title{
Judicialização das Ações de Vigilância em Saúde: o caso da Leishmaniose Visceral
}

\author{
Viviane Fragoso de Moura Lane ${ }^{1}$; Lucia Regina Montebelho Pereira ${ }^{2}$; Vitor Larte Pinto \\ Júnior $^{3}$
}

1. Bióloga, Mestre e Doutoranda do Programa de Pós-graduação em Ciências Médicas da Universidade de Brasília-UNB.

2. Médica Veterinária, Mestre em Saúde Pública. Consultora do Ministério da Saúde.

3. Médico, Mestre e Doutor em Medicina Tropical. Pesquisador da Fundação Oswaldo Cruz de Brasília e Universidade de Brasília.

\section{Resumo}

A leishmaniose visceral (LV) é uma zoonose de transmissão vetorial, evolução crônica e de elevada letalidade que se apresenta em franca expansão no território brasileiro. $\mathrm{O}$ objetivo do estudo foi descrever o perfil epidemiológico no período 2005-2009 das capitais de Belo Horizonte, Campo Grande, Fortaleza, Palmas e os instrumentos judiciais oriundos do Ministério Público direcionados ao controle da LV. Realizou-se um estudo descritivo e retrospectivo levantando-se dados epidemiológicos do Sistema Nacional de Agravos de Notificação, e analisando-se os Termos de Ajustamento de Conduta e das Ações Judiciais relativas à LV. Observou-se que há tendência ao aumento do número de casos da doença e que a atuação do Ministério Público se concentra nas ações de eliminação do reservatório doméstico. O processo de judicialização das ações de vigilância em saúde tira da esfera técnica as decisões sobre o controle da doença, interferindo nos eixos estruturantes da estratégia de controle da LV. Todavia novos estudos devem ser realizados para se avaliar o impacto dessa interferência nos indicadores epidemiológicos da LV.

Palavras-chave: Leishmaniose visceral, vigilância em saúde, judicialização.

\section{Introdução}

A leishmaniose visceral (LV) é uma zoonose de transmissão vetorial de evolução crônica e que pode levar ao óbito se não tratada, cerca de $90 \%$ dos casos mundiais de LV ocorrem em Bangladesh, Nepal, Brasil, Sudão e Índia. Atualmente a situação epidemiológica da LV no Brasil é preocupante pela sua crescente urbanização e expansão territorial $(1,2)$. 
As medidas de controle existentes para a LV são direcionadas para três eixos de atuação: detecção precoce e tratamento de casos humanos; controle dos reservatórios domésticos; e controle dos vetores da doença (3). Do ponto de vista social, as ações de vigilância relacionadas ao reservatório doméstico (cão) são as mais polêmicas, em decorrência da eutanásia de cães infectados e a contraindicação do tratamento canino como ferramenta para bloqueio da transmissão (4).

Apesar dos intensos esforços do poder público, as medidas de controle da doença têm se demostrado alcance muito aquém dos objetivos propostos (5, 6). Adicionalmente, verifica-se no país um processo de ajuste institucional, em que o Ministério Público adquire importância em decorrência da ampliação do acesso à justiça. Essa instância tem atuado como um defensor dos interesses coletivos assumindo um papel de controle e revisão da atuação dos poderes da República, principalmente do Poder Executivo. $(7,8)$.

A judicialização de questões ligadas ao direito constitucional à saúde tem assumido grande importância na relação entre a sociedade e gestores, principalmente nas áreas de assistência à saúde e farmacêutica. Esse trabalho tem o objetivo de descrever as orientações do MP contidas nos Termos de Ajustamento de Conduta (TAC) assinados ou propostas aos gestores municipais de quatro capitais brasileiras que interferem diretamente em ações da Vigilância em Saúde, especificamente no controle da LV.

\section{Metodologia}

Foi realizado um estudo descritivo e retrospectivo dos TACs assinados ou propostos aos gestores públicos da saúde que continham orientações de mudanças nas ações de vigilância e controle da LV entre os anos de 2005 e 2009 em quatro capitais brasileiras.

\section{Seleção dos Municípios}

Foram selecionadas as capitais que apresentavam os seguintes critérios: a) notificação de casos autóctones de Leishmaniose Visceral (LV); b) estar incluído na lista dos municípios prioritários do Programa Nacional de Leishmaniose Visceral do Ministério da Saúde (2007 a 2009); c) ser classificado como município de transmissão intensa de LV, ou seja, média de casos nos últimos cinco anos $\geq 4,4$ casos (diretrizes da vigilância epidemiológica e controle do Programa Nacional de Contro le da Leishmaniose Visceral - 
SVS/MS); e d) apresentar TAC (termo de ajustamento de conduta e/ou ação judicial) firmado ou impetrado contra o gestor, com as solicitações direcionadas ao programa nacional de vigilância e controle da LV.

\section{O Ministério Público (MP) e o Termo de Ajustamento de Conduta (TAC)}

O MP é uma instituição permanente, essencial à função jurisdicional do Estado, incumbindo-lhe a defesa da ordem jurídica, do regime democrático e dos interesses sociais e individuais indisponíveis (9). Tem como função privativa a ação penal pública, na forma da lei; o inquérito civil e a ação civil pública, para a proteção do patrimônio público e social, do meio ambiente e de outros interesses difusos e coletivos; dentre outras atribuições.

O TAC é um instrumento jurídico pelo qual a pessoa, reconhecendo implicitamente que sua conduta ofende ou pode ofender interesse difuso e coletivo, assume o compromisso de eliminar a ofensa ou o risco através da adequação de seu comportamento às exigências legais, mediante a formalização de termo com força de título executivo extrajudicial. É o termo, portanto, um contrato formado pelo interessado junto ao ente da administração pública legitimado a agir na tutela do direito em causa, contrato esse marcado por uma tração no sentido da busca de uma das partes em adequar-se a determinadas condições postas pela outra, dentro de parâmetros legais aplicáveis (9)

Os instrumentos selecionados foram extraídos diretamente de processos e das ações judiciais oriundas do Ministério Público Estadual de cada município selecionado, sendo eles: a) Campo Grande: processo n 20070152379 do Tribunal de Justiça do estado de Mato Grosso do Sul e processo n 137925020104030000 do Tribunal Regional Federal da $3^{\text {a }}$ região; b) Belo Horizonte: Tribunal de Justiça do estado de Minas Gerais apelação cível $n^{\circ}$ 1.0024.03.038441-6/002 e apelação cível n 1.0024.03.038441-6/002 - Comarca de Belo Horizonte; c) Fortaleza: Ministério Público do estado do Ceará Procuradoria Geral da Justiça, procedimento administrativo $\mathrm{n}^{\circ}$ 112/07, 30 /07/2008; d) Palmas: Termo de Compromisso de Ajustamento de Conduta - inquérito civil no 2010.3.29.25.0007.

\section{Dados Epidemiológicos, Econômicos e Demográficos}

As informações sobre a epidemiologia da LV no Brasil foram extraídas do Sistema Nacional de Agravos de Notificação (SINAN) e os dados populacionais foram obtidos do 
censo de 2010 realizado pelo Instituto Brasileiro de Geografia e Estatística. Os dados foram inseridos em planilha do Excel 2010 para Windows e foram realizadas análises estatísticas por meio de medidas de tendência central (média) e construídos indicadores de incidência, mortalidade e letalidade.

As informações sobre os indicadores de desenvolvimento humano municipal e nacional foram extraídas do sítio na internet do Programa das Nações Unidas para o Desenvolvimento (www.pnud.org.br) e os dados sobre Produto Interno Bruto dos municípios e do Brasil das publicações do IBGE Contas Nacionais e da Sinopse do Censo de 2010 (10, 11).

\section{Questões Éticas}

Este estudo foi conduzido de acordo com as determinações legais sobre ética em pesquisa vigentes no Brasil e foi dispensado de avaliação por um Comitê de Ética em Pesquisa por utilizar dados de domínio público.

\section{Resultados}

Foram selecionados os municípios de Fortaleza, Palmas, Belo Horizonte e Campo Grande, respectivamente capitais dos estados do Ceará (Região Nordeste), Tocantins (Região Norte), Minas Gerais (Região Sudeste) e Mato Grosso do Sul (Região Centro Oeste). As características demográficas e socioeconômicas desses municípios são descritas na tabela 1.

Tabela 1 - Indicadores demográficos e socioeconômicos de Fortaleza, Belo Horizonte, Palmas e Campo Grande para o ano de 2009.

\begin{tabular}{ccccc}
\hline UF & Local & População & PIB per Capta (R\$) & IDH \\
\hline CE & Fortaleza & 2.452 .185 & $10.066,00$ & 0,786 \\
\hline MG & Belo Horizonte & 2.375 .151 & $15.835,00$ & 0,839 \\
\hline MS & Campo Grande & 786.797 & $12.346,00$ & 0,814 \\
\hline TO & Palmas & 228.332 & $12.638,00$ & 0,800 \\
\hline- & Brasil & 190.755 .799 & $16.917,66$ & 0,718
\end{tabular}

Fonte: IDH-M - Índice de Desenvolvimento Humano (para os munícipios ano de 2000, para o Brasil 2011). PIB - Produto Interno Bruto em 2009. 
Em relação aos indicadores epidemiológicos, Fortaleza foi o município que apresentou maior número de casos autóctones de LV, com uma média de 188 casos-ano. Os óbitos foram mais frequentes em Belo Horizonte assim como a letalidade média da doença para o período. Os indicadores epidemiológicos foram descritos na tabela 2 e a evolução da incidência de LV no período de estudo se encontrada ilustrada na figura 1.

Tabela 2 - Indicadores Epidemiológicos para a Leishmaniose Visceral nas capitais selecionadas, média para os anos de 2005-2009. Indicadores (média dos anos de 2005 a 2009)

\begin{tabular}{cccccc}
\hline Localidade & Casos $^{\mathbf{1}}$ & Óbitos $^{\mathbf{1}}$ & Incidência $^{2}$ & $\begin{array}{c}\text { Mortalidade } \\
\text { Geral }^{2}\end{array}$ & $\begin{array}{c}\text { Letalidade } \\
(\boldsymbol{\%})\end{array}$ \\
\hline Fortaleza & 188,0 & 7,6 & 7,2 & 0,3 & 4,0 \\
\hline Belo Horizonte & 133,0 & 11,8 & 5,4 & 0,5 & 8,9 \\
\hline Campo Grande & 141,2 & 7,6 & 18,7 & 1,0 & 5,4 \\
\hline Palmas & 36,8 & 1,0 & 15,6 & 0,4 & 2,7 \\
\hline
\end{tabular}

1- Número absoluto

2- por 100.000 hab.

Figura 1. Evolução da Incidência da Leishmaniose Visceral nas capitais selecionadas, 2005-2009.

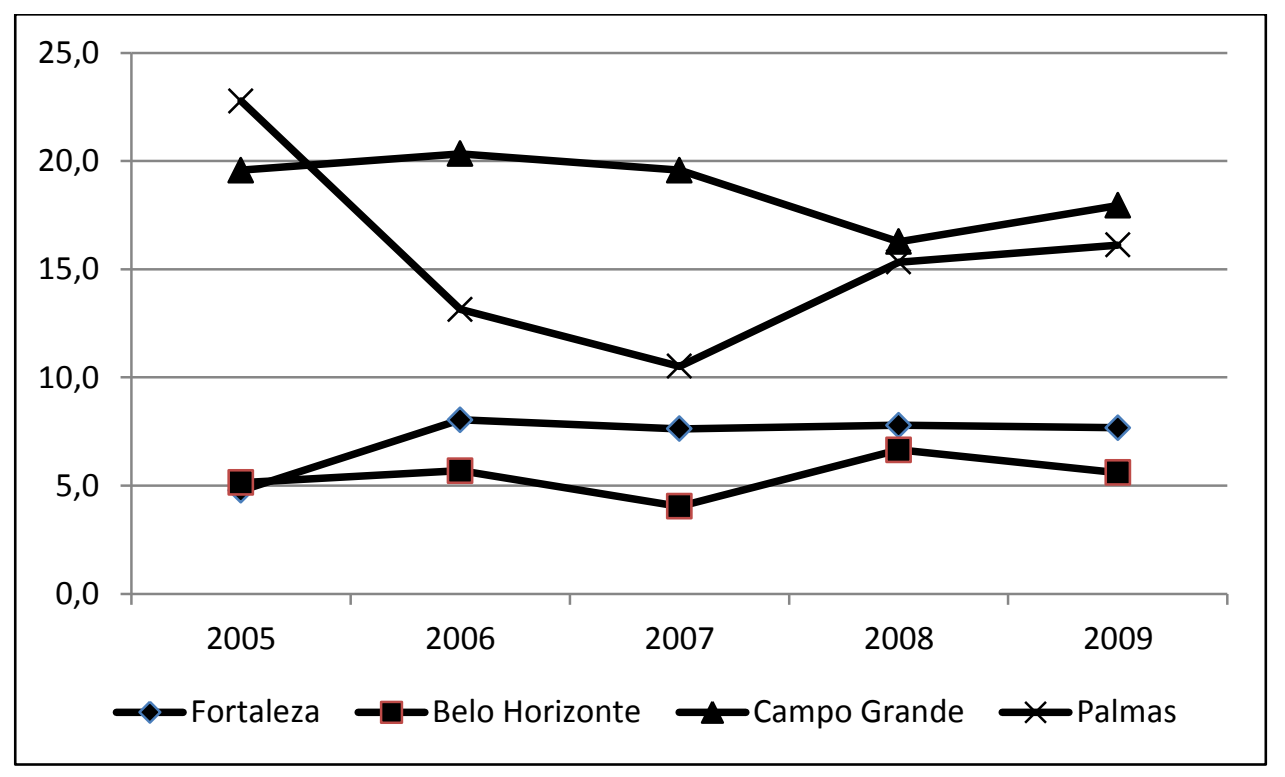

Verificou-se que a interferência do MP nas capitais selecionadas concentrou-se nos procedimentos de controle epidemiológico da LV para as ações de controle de reservatórios domésticos realizados pelas Secretarias Municipais de Saúde, por meio dos Centros de Controle de Zoonoses (CCZs). 
Os TACs e as Ações Civis Públicas apresentaram recomendações à gestão pública semelhantes em todos os municípios. Os três eixos que se basearam as ações foram: a) descontinuação da eutanásia de animais infectados, justificando a realização desse procedimento somente em casos terminais e intratáveis; b) suspensão da proibição do tratamento da LV canina e fornecimento de medicamentos de uso humano e vacinas de uso animal para esse fim; c) realização do diagnóstico confirmatório por método direto, considerando a acurácia questionável dos testes sorológicos realizados pelos CCZs e laboratórios autorizados (Imunofluorescência Indireta e ELISA).

\section{Discussão}

A partir do perfil epidemiológico das capitais estudadas, pôde-se evidenciar que a LV vem se comportando de maneira hiperendêmica nesses grandes centros urbanos, havendo o risco potencial para o desencadeamento de epidemias e servindo como exemplo de falência das políticas públicas de controle. A esse contexto soma-se a interferência do Ministério Público nas atividades operacionais de controle do reservatório doméstico, contribuindo para a descontinuidade das ações de controle, questionando a validade do diagnóstico e impondo o tratamento canino, procedimento este não autorizado no País.

A importância da LV no Brasil se deve a sua expansão territorial e ao potencial de causar epidemias, podendo assumir formas graves e letais principalmente quando acomete populações pobres e marginalizadas do processo social, sendo considerada uma doença reemergente e negligenciada (5). O ciclo urbano da doença tem como reservatório principal o cão, sendo que a prática de eutanásia dos animais doentes e/ou infectados é recomendada na atualidade para interrupção do ciclo de transmissão. No Brasil, o Ministério da Saúde reconhece a existência de grande contingente de animais nessa condição nos centros urbanos de grande e médio porte (12).

A questão social gerada pela política de eutanásia dos cães infectados, todavia com quadro clínico inaparente, e a proibição do tratamento/profilaxia quimioterápica para animais no Brasil, leva a movimentação de entidades não governamentais, principalmente ligadas à defesa animal, a acionarem o Ministério Público para que seus interesses possam ser atendidos (13). Essas demandas não levaram em consideração outros aspectos que certamente propiciam o descontrole da LV nas cidades estudadas. A urbanização e o fluxo migratório da população rural para os grandes centros, o crescimento desordenado das cidades com invasão 
de ambientes silvestres e a adaptação do vetor da doença Lutzomya longipalpis ao ambiente urbano, são fatores intimamente relacionados à expansão territorial da doença que não foram abordados nos TACs (6).

A inserção de instâncias judiciais no campo da saúde pode ser percebida como forma de "judicialização da política" no qual o judiciário pode interferir diretamente na política planejada pelo Poder Executivo, o que faz com que as medidas de controle centradas em bases técnicas passem a ser tomadas na esfera judicial (9). Nesse tocante, verificou-se também que não foi contemplada a abordagem de procedimentos voltados ao controle vetorial LV, das questões ambientais, bem como a situação da atenção à saúde humana, como melhoria da atenção primária de saúde ofertada pelo poder público aos usuários do sistema e o acesso ao diagnóstico laboratorial, limitando-se à defesa de direitos difusos consubstanciados nos direitos dos animais, com vistas a evitar procedimentos de eutanásia considerados desnecessários.

As práticas de controle focadas na eliminação do reservatório, no controle entomológico e no tratamento do caso humano vêm se mostrando poucos resultados positivos até o presente e há ainda muitos questionamentos sobre a eficácia dessas práticas na literatura $(3,14)$. No contexto nacional, as principais dificuldades encontradas residem na descontinuidade e na falta de sustentabilidade dessas ações pelo poder executivo (6), tornando a avaliação dessas ações problemática e dificultando a análise da contribuição da judicialização para o quadro epidemiológico nas cidades estudadas. Novos estudos científicos devem ser realizados para se determinar até que ponto o impedimento da eliminação do reservatório contribui para a expansão da doença no país e contemplando também a demanda social acarretada por essa ação.

\section{Referências:}

1. Guerin PJ, Olliaro P, Sundar S, Boelaert M, Croft SL, Desjeux P, et al. Visceral Leishmaniasis: current status of control, diagnosis, and treatment, and a proposed research and development agenda. The Lancet Infectious Diseases. 2002;2:494-501.

2. World Health Organization. Urbanization: an increasing risk factor for Leishmaniasis. Wkly Epidemiol Rec. 2002;77(44):365-70.

3. Romero GAS, Boelaert M. Control of Viceral Leishaniasis in Latin America A Systematic Review. Plos Neglected Tropical Diseases. 2010;4(1). 
4. Brasil. Manual de Vigilância e Controle da Leishmaniose Visceral. 1a. ed. Brasília, DF: Ed MS; 2003. 120 p.

5. Gontijo CMF, Melo MN. Leishmaniose visceral no Brasil: quadro atual, desafios e perspectivas. Revista Brasileira de Epidemiologia. 2004;7:338-49.

6. Barreto ML, Teixeira MG, Bastos FI, Ximenes RA, Barata RB, Rodrigues LC. Successes and failures in the control of infectious diseases in Brazil: social and environmental context, policies, interventions, and research needs. Lancet. 2011;377(9780):1877-89.

7. Carvalho ER. Em busca da judicialização da política no BraCsil: apontamentos para uma nova abordagem. Revista de Sociologia e Política. 2004:127-39.

8. Carvalho E, Leitão N. O novo desenho institucional do Ministério Público e o processo de judicialização da política. Revista Direito GV. 2010;6:399-422.

9. Arantes RB. Direito e política: o Ministério Público e a defesa dos direitos coletivos. Revista Brasileira de Ciências Sociais. 1999;14:83-102.

10. Instituto Brasileiro de Geografia e Estatística. Produto Interno Bruto dos Municípios 2005-2009. 2011.

11. Instituto Brasileiro de Geografia e Estatística. Sinopse do Censo Demográfico 2010. 2011.

12. Brasil, Ministério da Saúde. Manual de Vigilância e Controle da Leishmaniose Visceral. In: Saúde SdVe, editor. $1^{\text {a }}$ edição ed: Série A. Normas e Manuais Técnicos; 2006. p. 120.

13. Brasil, Ministério da Saúde, Ministério da Agricultura, Agropecuária e Abastecimento. Portaria interministerial no 1.426, de 11 de julho de 2008. Proíbe o tratamento de leishmaniose visceral canina com produtos de uso humano ou não registrados no Ministério da Agricultura, Pecuária e Abastecimento., (2008).

14. World Health Organization. Control of the Leishmaniasis: report of a meeting of the WHO Expert Committee on the Control ofLeishmaniases, Geneva, 22-26 March 2010. Geneva: World Health Organization; 2010. 186 p. 
ARTIGO 2 : A inserção da atenção primária à saúde nos casos de Leishmaniose Visceral Humana

Artigo submetido para publicação segundo as normas da Revista Cadernos de Saúde ColetivaUniversidade Federal de São Paulo- UNIFESP, em 07 de Dezembro de 2015. 


\title{
A inserção da atenção primária à saúde nos casos de Leishmaniose Visceral Humana
}

\author{
Viviane Fragoso de Moura Lane ${ }^{1}$, Sónia Maria Ferreira Dias², Vitor Laerte Pinto \\ Júnior $^{3}$
}

1. Doutoranda em Ciências Médicas, Universidade Brasília, Brasília, DF, Brasil.

2. Pesquisadora do Instituto de Higiene e Medicina Tropical da Universidade Nova de Lisboa, Lisboa, Portugal.

3. Pesquisador da Fundação Oswaldo Cruz de Brasília, Brasília-DF, Brasil; Investigador de Pós-doutorado do Instituto de Higiene e Medicina Tropical da Universidade Nova de Lisboa, Lisboa, Portugal.

\section{RESUMO}

Introdução: O Programa Nacional de Vigilância e Controle preconiza que a atenção aos casos da Leishmaniose visceral Humana (LVH) envolve um diagnóstico precoce e o tratamento adequado. Contudo, a efetivação dessas ações de atenção primária à saúde ainda é um tema em debate, haja vista a complexidade do diagnóstico e da terapêutica da doença. Este trabalho tem como objetivo, analisar o conhecimento, práticas profissionais e a atenção aos casos diagnosticados em um território endêmico do Distrito Federal. Métodos: Estudo descritivo exploratório e quantitativo. Aplicou-se um questionário semiestruturado aos profissionais de saúde, enfermeiros e médicos das especialidades de clínica médica, pediatria e saúde da família pertencentes às unidades de atenção básica à saúde das regiões de Sobradinho I e II com abrangência à área da Fercal. Resultados: Os participantes demonstraram a relevância da Leishmaniose Visceral Humana no contexto da atenção primária à saúde. Contudo, as unidades básicas de saúde enfrentam dificuldades em operacionalizá-las, pois apenas $29 \%$ dos profissionais afirmaram ter exames disponíveis para o diagnóstico, e 90\% dos entrevistados afirmaram não haver infraestrutura e capacitação profissional adequada para essas ações. Conclusão: É necessária a integração da doença às ações da atenção primária à saúde de forma a potencializar o tratamento e diagnóstico nesse âmbito. 


\section{Introdução}

A Leishmaniose Visceral Humana (LVH), ou calazar, é uma zoonose de caráter crônico causada no Brasil pela Leishmania infantum (sinônimo chagasi). ${ }^{(1,2)}$ Segundo a Organização Mundial de Saúde-OMS, a LVH é considerada uma das doenças parasitárias de maior impacto para a saúde pública mundial, com cerca de 500.000 casos estimados anualmente e 310 milhões de pessoas em risco de adquirir a doença no Mundo. Dados acerca da letalidade da doença são imprecisos, estimando-se que seja de cerca de $10 \%$, portanto o número de mortes anualmente pode alcançar até 50.000 pessoas. É endêmica em 65 países e cerca de $90 \%$ dos casos notificados ocorrem principalmente em regiões pobres da Índia, Bangladesh, Nepal, Sudão, Etiópia e Brasil ${ }^{(3-5)}$

A transmissão é indireta por meio da picada de flebotomíneos, cujo principal espécie no Brasil é a Lutzomya longipalpis, amplamente distribuída no território brasileiro. A transmissão envolve também a participação de mamíferos que funcionam como reservatórios da doença. No ambiente silvestre, é representado principalmente pelas raposas da espécie Cerdocyon thous e marsupiais (Dipelphis albiventris) e no urbano pelo cão doméstico (Canis familiares). ${ }^{(6-8)}$

Clinicamente a LVH varia desde casos oligo ou assintomático até formas graves, com letalidade de até $90 \%$ se não tratada adequadamente, caracterizada por febre de longa duração, emagrecimento, hepatomegalia hipergamaglobulinemia e pancitopenia. ${ }^{(9,}$ 10) Representa um grande problema de saúde pública e que historicamente vem ampliando a sua magnitude no Brasil, apesar das ações de controle empreendidas. ${ }^{(3,11)}$

A atenção aos casos da doença, que envolve o diagnóstico e o tratamento, é uma das estratégias propostas pelo Programa Nacional de Vigilância e Controle da Leishmaniose Visceral. ${ }^{(6)}$ Para a consecução dessa ação, além de laboratórios de saúde pública com disponibilidade do teste diagnóstico, profissionais de saúde devem estar cientes da epidemiologia da doença em seu território e ter conhecimentos para a suspeição e tratamento da doença.

A inserção do cuidado individual dos casos de LVH na atenção básica de saúde ainda é tema controverso e de difícil efetivação, em decorrência da complexidade do diagnóstico e da terapêutica da doença. ${ }^{(12)} \mathrm{O}$ presente estudo objetivou analisar o conhecimento e práticas de profissionais de saúde inseridos em um território endêmico para $\mathrm{LVH}$ e na atenção recebida dos casos diagnosticados no Distrito Federal (DF) do Brasil. 


\section{Métodos}

\section{Delineamento do Estudo}

Pesquisa descritiva exploratória e quantitativa, aplicando-se um questionário estruturado aos profissionais de saúde lotados na atenção básica das regiões de Sobradinho I e II e Fercal, entre novembro e dezembro de 2014. Essas áreas de estudo, cuja população é estimada em 170 mil habitantes, ${ }^{(13)}$ foram selecionadas por apresentarem a maior detecção de casos de LVH autóctone no DF de acordo com os relatórios da Diretoria de Vigilância Epidemiológica, pertencente à Secretaria de Estado de Saúde do Distrito Federal DIVEP/SES-DF. ${ }^{(14)}$

\section{Área de Estudo}

A assistência da atenção básica de Sobradinho I é composta por cinco Unidades Básicas de Saúde (UBS): Águia, Arara, Bem-te-vi, Beija-Flor, João Barro e Sabiá; uma Clínica da Família de Nova Colina e as equipes da ESF: Nova Colina, Nova Dignéia, Córrego do Arrozal, Rota do Cavalo, Lara e Uberaba.

Em Sobradinho II, há as ESF's: Buritizinho, Serra Azul e Morada da Serra; as UBS's: Vale dos Pinheiros, Vale das Acácias, e uma Clínica da Família, composta por uma ESF (Bem-me-quer).

A Fercal é formada por 14 comunidades, das quais seis são rurais (Boa Vista, Catingueiro, Córrego de Ouro, Engenho Velho, Ribeirão-Pedreira) e as demais são urbanas. É vista como uma das áreas mais pobres do DF e se insere na Área de Proteção Ambiental (APA) de Contagem. O núcleo populacional se desenvolveu a partir da instalação de duas fábricas de cimento na década de 80 , causando a ocupação irregular do solo com consequente desequilíbrio ambiental. Nesta região administrativa há duas UBS’s: Queima Lençol e Alto Belo Vista, e duas ESF's: Engenho Velho e Catingueiro (13). 


\section{Participantes}

O critério de seleção dos profissionais de saúde (enfermeiros e médicos das especialidades de pediatria, clínica médica e médicos da família) considerou a atuação direta em atividades assistenciais nas UBS's, constatando-se 41 profissionais nessas condições, dos quais 23 concordaram em participar da pesquisa.

\section{Procedimentos}

Os questionários foram aplicados a 23 profissionais de saúde das regionais de Sobradinho I e II e da Fercal, sendo dez enfermeiros e os demais profissionais médicos, distribuídos nas especialidades: pediatria (dois), clínica médica (sete) e médicos da família (quatro).

O questionário foi estruturado em questões fechadas e abordou as seguintes questões: 1) opinião a respeito da importância epidemiológica da LVH nas regiões, 2) conduta diante de um caso confirmado de LVH na unidade de saúde, 3) importância da atenção primária aos casos LVH, 4) informação sobre a disponibilidade de exames para o diagnóstico pré/póstratamento de LVH na unidade de saúde; e fechadas: 5) infraestrutura para o diagnóstico e tratamento da LVH, 6) a existência de capacitações profissionais para o diagnóstico e tratamento da LVH e 7) importância da atenção primária aos casos de LVH.

Os dados dos questionários foram inseridos em uma planilha e analisados por meio de ferramentas de estatística descritiva. Cabe salientar que as respostas não respondidas foram classificadas como ignoradas.

O desenvolvimento do estudo obedeceu às normas de ética em pesquisa envolvendo seres humanos.

\section{Resultados}

\section{Importância epidemiológica da LVH no território}

O questionamento acerca da existência da LVH na região resultou que apenas dois $(8,7 \%)$ profissionais afirmaram que a LVH não existia na região endêmica e dez $(43,5 \%)$ não tinham qualquer informação acerca da doença. Do restante, 11 (47,8\%) profissionais, reconheceram a importância epidemiológica da doença, apontando como fatores relevantes o 
risco decorrente do convívio com as condições propícias para a transmissão da doença $(45,5 \%)$; o desconhecimento sobre a forma de transmissão da doença $(36,4 \%)$ e o grande número de casos e letalidade na região $(18,2 \%)$, conforme tabela 1.

Tabela 1. Fatores relevantes para ocorrência da Leishmaniose Visceral Humana nas regiões de Sobradinho I, II e Fercal, Distrito Federal, Brasil, Novembro e Dezembro de 2014.

Fatores relevantes Número de Participantes Percentual

Risco decorrente do convívio com as condições

propícias para a transmissão da doença

5

$45,5 \%$

Desconhecimento sobre a forma de transmissão

4

$36,4 \%$

Grande número de casos de LV e letalidade na

região

$\mathrm{N}: 11$

Fonte: dados da pesquisa

\section{Conduta diante de um caso confirmado}

$\mathrm{Na}$ tabela 2, são demonstrados os resultados acerca da conduta adotada pelos profissionais em face de um caso confirmado de LVH. Pode-se observar que $56,5 \%$ dos entrevistados indicaram a realização de contato com a vigilância epidemiológica, 30,4\% o encaminhamento para o serviço de referência no tratamento da $\mathrm{LVH}$, e 17,4\%, o tratamento do paciente. A maior parte dos profissionais entrevistados (95\%) nunca presenciou e nem suspeitou de casos de LVH na sua unidade.

Tabela 2. Conduta profissional adotada em um caso confirmado, Distrito Federal, Brasil, Novembro e Dezembro de 2014.

\begin{tabular}{lcc}
\hline Conduta diante de um caso confirmado & Número de Participantes & Percentual \\
\hline $\begin{array}{l}\text { Realização de contato com a vigilância } \\
\text { epidemiológica }\end{array}$ & 13 & $56,5 \%$ \\
$\begin{array}{l}\text { Encaminhamento para o serviço de } \\
\text { referência no tratamento da LVH }\end{array}$ & 7 & $30,4 \%$ \\
$\begin{array}{l}\text { Tratamento do paciente } \\
\text { Inexistência de casos de LVH na região }\end{array}$ & 4 & $17,4 \%$ \\
\hline
\end{tabular}

$\mathrm{N}: 23$

Fonte: dados da pesquisa 


\section{Disponibilidade de exames para o diagnóstico pré e pós-tratamento}

A respeito dos exames disponíveis para o diagnóstico e tratamento, apenas 30,5\% dos profissionais afirmaram ter exames disponíveis, tais como sorologia $(42,9 \%)$, de função hepática (14,3\%), hemograma (28,6\%), ultrassonografia abdominal (14,3\%), eletrocardiograma $(28,6 \%)$ e outros exames clínicos $(85,7 \%)$. Os exames pós-tratamento mais relevantes pelos participantes foram o de função hepática, hemograma e exames clínicos, conforme demonstrado na tabela 3.

Tabela 3. Disponibilidade de exames para o acompanhamento dos casos de LVH

\begin{tabular}{lcc}
\hline Exames disponíveis & Número de Participantes & Percentual \\
\hline Sorologia & 3 & $42,9 \%$ \\
Função Hepática & 1 & $14,3 \%$ \\
Hemograma & 2 & $28,6 \%$ \\
Ultrassom & 1 & $14,3 \%$ \\
Eletrocardiograma & 2 & $28,6 \%$ \\
Exames Clínicos & 6 & $85,7 \%$ \\
\hline
\end{tabular}

$\mathrm{N}: 7$

Fonte: dados da pesquisa

\section{Infraestrutura para o diagnóstico e tratamento}

Em relação à infraestrutura oferecida nas UBS's para o acompanhamento dos casos de LVH na região, 90\% dos profissionais relataram a inexistência de condições para o diagnóstico, realização de exames e tratamento da LVH no local. Apesar da totalidade dos entrevistados afirmarem a importância da atenção básica no diagnóstico e tratamento nos casos de LVH, a maioria (90\%) reconhece que não há infraestrutura e capacitação profissional adequada para as ações nesse âmbito.

\section{Discussão}

O desconhecimento dos profissionais de saúde acerca da situação epidemiológica da LVH e dos determinantes ligados à sua ocorrência em territórios comprovadamente endêmicos para doença é um obstáculo à manutenção das medidas de controle propostas pela Organização Mundial da Saúde (OMS) e pelo Ministério da Saúde (MS) do Brasil . ${ }^{(15)}$ 
Adicionalmente, a ausência de infraestrutura para o diagnóstico e o tratamento nos serviços de saúde da atenção básica contribui para o atual quadro epidemiológico de expansão da doença no Brasil. ${ }^{(16)}$

A LVH no Brasil apresenta-se em expansão. Apesar da existência de programas de controle, o DF se encontra em área de transmissão da doença, sendo notificados cerca de 50 casos por ano. A maior parte dos casos se concentra na região estudada (12\%), que apresenta problemas ambientais e sociais que contribuem para a manutenção da transmissão. ${ }^{(14,17)}$ Apesar desse perfil epidemiológico, a pesquisa revelou o desconhecimento da doença na região pelos profissionais pertencentes às ESF's, pois a metade deles afirmou a inexistência de transmissão da LVH. Esse resultado pode ser explicado pelo encaminhamento ou procura direta dos pacientes com quadros febris prolongados para unidades de saúde de maior complexidade com o objetivo de se realizar o diagnóstico.

O aumento da tendência temporal da mortalidade e letalidade da LVH no Brasil foi tratado em estudo recente ${ }^{(7)}$, sendo este fenômeno determinado à fatores clínicos observados em decorrência da progressão da doença no indivíduo. ${ }^{(18)}$ Portanto, o correto diagnóstico de forma precoce é fulcral para as políticas de saúde pública, e envolve a atuação do profissional nesse sentido nos territórios endêmicos. O diagnóstico precoce é fundamental para início do tratamento, reforçando a necessidade de realização de treinamentos periódicos para a capacitação no manejo da doença. Um estudo realizado em Campo Grande/MS, ${ }^{(9)}$ com 55 casos que evoluíram ao óbito, ressalta a necessidade de profissionais capacitados para o reconhecimento precoce da doença e monitoramento clínico e laboratorial dos pacientes durante o tratamento da doença, a fim de identificar também precocemente possíveis complicações.

O estudo demonstrou ainda a dificuldade enfrentada pelas UBS quanto a sua estrutura para atendimento e acompanhamento dos casos de LVH. Em virtude disso, a maioria dos casos suspeitos ou confirmados é direcionada à unidade referenciada de alta complexidade da região. De acordo a Secretaria de Vigilância à Saúde, no período de 2011 a 2015 o Hospital Regional de Sobradinho (HRS), unidade hospitalar de média complexidade, foi referência para as UBS's e é uma das unidades que mais recebem atendimentos de LVH quando comparada às demais unidades do DF. ${ }^{(19)}$ Esses resultados corroboram com o estudo no qual foi demonstrado que a precariedade na estrutura da UBS's contribuiu significativamente para o atraso na confirmação do diagnóstico e o início do tratamento. ${ }^{(12)}$ 
A prevenção da LVH envolve intervenções ambientais por parte das autoridades sanitárias e da população de forma a interromper a cadeia de transmissão, no que diz respeito ao controle vetorial e dos reservatórios domésticos. ${ }^{(3)}$ A educação e a percepção da população acerca das medidas de controle do ambiente doméstico demonstrou ser eficaz na diminuição de casos da doença. ${ }^{(20-22)}$ A proximidade dos profissionais com a população e as atribuições de educação em saúde da ESF vai ao encontro dessa evidência, todavia o estudo demonstrou que um quarto dos profissionais não conhecia a dinâmica de transmissão da LVH, o que pode prejudicar mais esse pilar do controle da parasitose.

A carência de profissionais de saúde e a falta de competência percebida por eles para abordar o problema complexo da LVH representa uma oportunidade perdida para o controle e tratamento adequado dos pacientes. ${ }^{12,23}$ Os dados reafirmam a dificuldade das ações de atenção primária quanto à disponibilidade de protocolos de orientação para tratamento da doença e exames necessários para o diagnóstico, os quais influenciam na disposição dos profissionais à adesão ao acompanhamento e tratamento dos casos ${ }^{12}$ e não deixa outra opção a não ser o manejo dos pacientes em unidades hospitalares, acarretando em piora do prognóstico e na sobrecarga dessas unidades.

O estudo abordou um território circunscrito de uma unidade da federação com transmissão autóctone de LVH, apesar desta limitação, o DF encontra-se inserido na realidade brasileira no que diz respeito ao funcionamento e características do Sistema Único de Saúde (SUS). Outro problema diz respeito à não concordância da participação de quase metade dos profissionais de saúde incluídos no estudo, muito embora as suas contratações por parte da Secretaria de Saúde do Estado seja uniformizada por meio de concursos públicos.

O estabelecimento da atenção básica como principal estratégia para a universalização da atenção à saúde recomendada pela Declaração de Alma Ata em $1978^{24}$ e que se procura estimular no âmbito do SUS, trouxe à tona diversas tentativas de se normatizar, ou orientar, as ações de saúde para a atenção básica. ${ }^{25-27}$ Contudo, ainda não há uma definição acerca da atuação desse nível em casos de atendimento de pacientes com LVH. Nesse contexto, os dados do estudo sinalizam a necessidade de reorganização do sistema de saúde do território para que a APS funcione efetivamente como porta de entrada do usuário ao sistema de saúde, e que possa atender às necessidades de saúde demandadas pelos habitantes do território. ${ }^{(12)}$

É necessária a integração das ações de prevenção e controle no âmbito da atenção primária à saúde de forma a apressurar o diagnóstico. 


\section{Referências}

1. Hamilton JG. Sandfly pheromones: Biology and Potential for use in control programs. Parasite. 2008; 15(3): 252-6.

2. BATES PA. Transmission of Leishmania metacyclic promastigotes by phlebotomine sand flies. Parasitology International. 2007; 37: 1097-1106.

3. Organização Mundial da Saúde. Report of the scientific working group meeting on Leishmaniasis. Geneva: WHO, 2012.

4. Chappuis F, Sundar S, Hailu A, Ghalib H, Rijal S, Peeling RW, Alvar J, Boelaert M. Visceral leihsmaniasis: What are the needs for diagnosis, treatment and control? Nat Rev Microbiol. 2007 Nov; 5(11): 873-82.

5. Gontijo CMF, Melo MN. Leishmaniose Visceral no Brasil: Quadro atual, Desafios e perspectivas. Rev Bras de Epidemiol. 2004; 7(3): 338-49. DOI: 10.1590/S1415$790 \times 2004000300011$

6. Brasil. Ministério da Saúde. Manual de Vigilância e Controle da Leishmaniose visceral. Brasília: Ministério da Saúde, 2014.

7. Martins-Melo FR, Lima MS, Ramos Jr AN, Alencar $\mathrm{CH}$, Heukelbach J. Mortality and Case Fatality Due to Visceral Leishmaniasis in Brazil: A Nationwide Analysis of Epidemiology, Trends and Spatial Patterns. Plos One. 2014; 9(4): 1-14.

8. Souza VMM, Julião FS, Neves RCS, Magalhães PB, Bisinotto TV, Lima AS, et. al. Ensaio comunitário para avaliação da efetividade de estratégias de prevenção e controle da leishmaniose visceral humana no Município de Feira de Santana, Estado da Bahia, Brasil. Epidemiol Serv Saude. 2008; 17(2): 97-106. DOI: 10.5123/S1679-49742008000200003.

9. Alvarenga DG, Escalda PMF, Costa ASV, Monreal MTFD. Leishmaniose Visceral: estudo retrospectivo de fatores associados à letalidade. Rev Soc Bras Med Trop. 2010; 43(2): 194-7. DOI: 10.1590/S0037-86822010000200017

10. Bern C, Courtenay O, Alvar J. Of Cattle, Sand Flies and Men: A Systematic Review of Risk Factor Analyses for South Asian Visceral Leishmaniasis and Implications for Elimination. PLoS Neg1 Trop Dis [Internet]. 2010; 4(3). [acesso em 12 jan 2015]. Disponível em: http://journals.plos.org/plosntds/article?id=10.1371/journal.pntd.0000599.

11. Harvah MO, Ollario PL, Costa DL, Costa CHN. Urban parasitology: visceral Leishmaniasis in Brasil. Trends Parasitol. 2011; 27(9): 403-9. 
12. Barbosa MN, Carmo RF, Oliveira DCD, Silva GC, Luz ZMP. Atenção aos casos humanos de Leishmaniose visceral no âmbito da atenção primária à saúde em município da região metropolitana de Belo Horizonte. Revista de APS. 2013; 16(3): 234-41.

13. Brasil. Distrito Federal. Companhia de Planejamento do Distrito Federal CODEPLAN. Pesquisa Distrital por Amostra de Domicílios. [acesso em 15 jan 2015]. Disponível em: http://www.codeplan.df.gov.br/images/CODEPLAN /PDF/Pesquisas\%20Socioecon\%C3\%B4micas/PDAD/2012/PDAD-DF-2011-091112.pdf

14. Brasil. Distrito Federal. Secretaria do Estado de Saúde. Diretoria de Vigilância Epidemiológica. Informativo Epidemiológico das Leishmanioses no DF. Ano 07, no 3. Julho de 2015. [acesso em 10 mai 2015]. Disponível em http://www.saude.df.gov.br/images/Leishmaniose/2015/Infor mativo_Epidemiologico_Leishmanioses_DF_3_2015.

15. Brasil. Ministério da Saúde. Manual de Vigilância e Controle da Leishmaniose visceral. Brasília: Ministério da Saúde, 2014.

16. Barreto ML1, Teixeira MG, Bastos FI, Ximenes RA, Barata RB, Rodrigues LC. Successes and failures in the control of infectious diseases in Brazil: social and environmental context, policies, interventions, and research needs. Lancet. 2011; 377 (9780): 1877-89. DOI: 10.1016/S0140-6736(11)60202-X.

17. Carranza-Tamayo CO, Carvalho MSL, Bredt A, Bofil MIR, Rodrigues RMB, Silva AD, Cortez SMFC, Romero GAS. Autochthonous visceral Leishmaniasis in Brasília, Federal District, Brazil. Rev Soc Bras Med Trop. 2010; 43(4): 396-9.

18. Sampaio MJ, Cavalcanti NV, Alves JG, Filho MJ, Correia JB. Risk factors for death in children with visceral Leishmaniasis. PLoS Negl Trop Dis. 2010; 4(11): e877. DOI: 10.1371/journal.pntd.0000877.

19. Brasil. Ministério da Saúde. Secretaria de Vigilância à Saúde - Sistema de informação de Agravos e Notificação - SINAN. [acesso em 10 jan 2015]. Disponível em: www.saude.gov.br/sinanweb.

20. Borges BKA, Silva JA, Haddad JPA, Moreira EC, Magalhães DF, Ribeiro LML, Fiúza VOP. Avaliação do nível de conhecimento e de atitudes preventivas da população sobre a leishmaniose visceral em Belo Horizonte, Minas Gerais, Brasil. Cad Saude Publica. 2008; 24(4): 777-84. 
21. Boraschi CSS, Perri SHV, Nunes CM. Leishmaniose visceral: O que a população de Três Lagoas, MS, Brasil, sabe sobre essa enfermidade? Vet e Zootec. 2008; 15(3): 478-85.

22. Luz ZMP, Schall V, Rabello A. Evaluation of a pamphlet on visceral Leishmaniasis as a tool for providing disease information to healthcare professional and laypersons. Cad Saude Publica. 2005; 21(2): 606-21.

23. Roecker S, Budó MLD, Marcon SS. Trabalho educativo do enfermeiro na estratégia Saúde da família: dificuldades e perspectivas de mudanças. Rev Esc Enferm USP. 2010; 46(3): 641-9. DOI: 10.1590/S0080-62342012000300016

24. Souza LGS, Menandro MCS. Atenção primária à saúde: diretrizes, desafios e recomendações. Revisão de bibliografia internacional. Physis. 2011; 21(2): 517-39. DOI: 10.1590/S0103-73312011000200010

25. Lavras C. Atenção primária à Saúde e a Organização das Redes Regionais de Atenção à Saúde no Brasil. Saude Soc. 2011; 20(4): 867-874. DOI: 10.1590/S010412902011000400005

26. Giovanella L, Mendonça MHM, Almeida PF, Escorel S, Senna MCM, Fausto MCR, et al. Saúde da família: limites e possibilidades para uma abordagem integral da atenção primária à saúde no Brasil. Cien Saude Colet. 2009; 14(3): 783-94. DOI: 10.1590/S1413-81232009000300014

27. Gil CRR. Atenção primária, atenção básica e saúde da família: sinergias e singularidades do contexto brasileiro. Cad Saude Publica. 2006; 22(6): 1171-81.DOI: 10.1590/S0102-311X2006000600006. 
Artigo 3: Evolução de casos assintomáticos de Leishmaniose visceral Humana em uma área endêmica do Distrito Federal-DF.

Artigo submetido para publicação segundo as normas da Revista Interface, Comunicação, Saúde e Educação em 07 de Dezembro de 2015. 


\section{Evolução de casos assintomáticos de Leishmaniose visceral Humana em área endêmica do Distrito Federal, Brasil.}

Viviane Fragoso de Moura Lane ${ }^{1}$, Vitor Laerte Pinto Júnior ${ }^{2}$

1. Universidade Brasília, Brasília, DF, Brasil.

2. Pesquisador da Fundação Oswaldo Cruz de Brasília, Brasília-DF, Brasil; Investigador de Pós-doutorado do Instituto de Higiene e Medicina Tropical da Universidade Nova de Lisboa, Lisboa, Portugal.

\section{Resumo}

O objetivo deste trabalho foi descrever a evolução clínica de indivíduos com o teste intradérmico Montenegro positivo a partir de um estudo de série de casos realizado no período de 2011 a 2014. Aplicou-se um questionário a 120 indivíduos residentes do território endêmico a Leishmaniose Visceral Humana no Distrito Federal-DF. Os dados foram analisados com o SPSS 19.0. Constatou-se que 62,5\% não conheciam acerca da doença na região. A falta de saneamento básico $(88,3 \%)$, precariedade da assistência à saúde $(77,5 \%)$ e proximidade das residências $(55 \%)$ à área de vegetação foram elencados pela população do estudo como determinantes à doença na região. Além disso, a maioria dos participantes apontaram a existência de cães dométicos em suas residência reafirmando o papel deste reservatório no território endêmico. Constatou-se, ainda, a evolução de um caso assintomático para a forma subclínica da doença. As investigações de fatores que condicionam A doença e o acompanhamento contínuo de pacientes assintomáticos permitem o entendimento da doença.

Palavras-chaves: Leishmaniose Visceral, epidemiologia, inquéritos

\section{Resumen}

El objetivo de este estudio fue describir la evolución clínica de los acientes con prueba cutánea positiva Montenegro desde un estudio de series de casos llevado a cabo entre 2011 y 2014. Se aplicó un cuestionario a 120 personas que residen en el territorio endémica Leishmaniasisvisceral humana en Distrito Federal-DF. Los datos fueron analizados con el programa SPSS 19.0. Se encontró que el 62,5\% no sabía nada de la enfermedad en la región. La falta de saneamiento $(88,3 \%)$, la atención de salud precaria $(77,5 \%)$ y la proximidad de los hogares $(55 \%)$ a la zona verde se destacó por la población de estudio como factores determinantes de la enfermedad en la región. Se encontró también la evolución de un caso asintomático de forma subclínica de la enfermedad. Las investigaciones de los factores que influyen en la enfermedad y el monitoreo continuo de pacientes asintomáticos permiten la comprensión de la enfermedad.

Palabras clave: Leishmaniasis visceral, la epidemiología, encuestas

\section{Abstract}


The objective of this study was to describe the clinical course of patients with positive Montenegro skin test from a case series study conducted from 2011 to 2014. It was applied a questionnaire to 120 individuals residing in the territory endemic Visceral Leishmaniasis Human in Federal District-DF. Data were analyzed with SPSS 19.0. It was found that $62.5 \%$ did not know about the disease in the region. The lack of sanitation $(88.3 \%)$, precarious health care $(77.5 \%)$ and proximity of homes $(55 \%)$ to the green area were highlighted by the study population as determinants of disease in the region. It was found also the evolution of an asymptomatic case for subclinical form of the disease. Investigations of factors that influence the disease and the continuous monitoring of asymptomatic patients allow the understanding of the disease.

Key words: Leishmaniasis Visceral, epidemiology, surveys

\section{INTRODUÇÃO}

A Leishmaniose Visceral (LV), ou kala-azar, é uma doença de evolução crônica uniformemente fatal se não tratada. De acordo com a OMS, a doença é considerada como negligenciada e é endêmica em 98 países com $90 \%$ dos casos se concentrando em Bangladesh, Nepal, Sudão, Índia e Brasil. Em 2010 havia um total de 200 milhões de pessoas em risco para aquisição da doença, sendo registrados cerca de 300.000 casos novos e entre 20.000 a 50.000 mortes anuais no Mundo. ${ }^{1-2}$

No Brasil é uma zoonose causada pela Leishmania infantum (syn chagasi) e transmitida pelas fêmeas do flebotomíneo Lutzomya longipalpis. São descritos dois ciclos de transmissão da doença, um silvestre mantido principalmente por raposas (Cerdocyon thous) e gambás (Dipelphis albiventris) e o outro doméstico cujo principal reservatório éo cão (Canis familiaris). Em ambos os ciclos o homem é considerado como hospedeiro acidental, já que sua infecção não é capaz de manter o ciclo de transmissão. ${ }^{3-6}$

A intradermorreação de Montenegro (IDRM) é um teste cutâneo que visa comprovar a infecção por Leishmania sp.em função de uma resposta celular tardia à antígenos do parasito. Tem utilidade diagnóstica, apesar de amplamente suplantada por técnicas sorológicas sendo, entretanto, ainda utilizada para este fim em países em desenvolvimento associada a critérios clínicos e epidemiológicos. ${ }^{7,8}$

Inquéritos populacionais realizados em diversas áreas endêmicas para a LVH utilizando-se a IDRM demonstram que a maior parte dos indivíduos é assintomática e que somente cerca de 20 a $30 \%$ destes evolui clinicamente para a doença. ${ }^{9-11}$

A existência de indivíduos assintomáticos apontam várias questões acerca do comportamento clínico e epidemiológico da LVH em áreas endêmicas. Um destes aspectos 
diz respeito à possibilidade de evolução para forma sintomática no decorrer do tempo, dado o longo período de incubação e a possibilidade de latência da doença. ${ }^{7}$

O presente estudo teve como objetivo descrever a evolução de indivíduos com IDRM positivo em um território endêmico de LVH no Distrito Federal do Brasil.

\section{METODOLOGIA}

\section{Delineamento do Estudo}

Foi realizado um estudo de série de casos entre os anos de 2011 e 2014 a partir de sujeitos que se apresentaram com IDRM positiva em inquérito realizado em população de área endêmica do Distrito Federal no ano de 2007.

\section{Área de estudo}

A região da Fercal localiza-se ao norte de Brasília, no Distrito Federal-DF, próximo às Regiões de Sobradinho e do Lago Norte. É considerada como uma das regiões mais pobres do DF e se insere um uma Área de Proteção Ambiental (APA) de Contagem. Estima-se uma população total de 8.536 habitantes. O núcleo populacional se desenvolveu a partir da instalação de duas fábricas de cimento na década de 80, causando a ocupação irregular do solo com consequente desequilíbrio ambiental. ${ }^{12}$

É composta por treze comunidades, das quais, quatro apresentam características tipicamente rurais com fazendas e ranchos e pouco habitantes (Boa Vista, Catingueiro, Córrego de Ouro, Ribeirão-Pedreira) e as demais são urbanas com a distribuição de casas próximas a florestas de savana (Bananal, Curvas, Engenho Velho, Fercal Leste e Queima Lençol).

\section{Procedimentos}

Foi realizado um inquérito populacional, no ano de 2007, que envolveu 700 participantes desta região com a finalidade de se estabelecer a prevalência da LV. Na ocasião, foram detectados 233 indivíduos com IDRM positiva. No presente estudo, entre 2011 a 2014, foram realizadas visitas domiciliares às comunidades da Fercal juntamente com os agentes comunitários de saúde (ACS) que dão a cobertura de assistência básica no local, a fim de identificar os pacientes com o teste de IDRM positiva, sendo encontrados $120(51,5 \%)$ destes indivíduos. 


\section{Instrumento de coleta e Variáveis}

Os participantes da pesquisa foram convidados a uma entrevista pessoal, a qual foi conduzida por meio de um questionário estruturado com questões constituídas por: características individuais (nome, idade, sexo, endereço e comunidade da residência); condições socioeconômicas (dados da moradia, nível de escolaridade e renda familiar); aspectos gerais da comunidade (saneamento básico, disposição do lixo e provisão da água); tópicos acerca da LVH: (conhecimento sob a doença, forma de transmissão, sintomologia (sinais e sintomas da doença), presença de animais domésticos (quantidade de cães e/outros animais na residência); formas de diagnóstico para a Leishmaniose visceral Humana e canina; e, por fim, a adoção de medidas de controle doença pelas autoridades de saúde (medidas de controle adotadas na comunidade) e acompanhamento dos indivíduos assintomáticos (IDRM positivos) pelas unidades básicas de saúde a fim de identificar o aparecimento de indivíduos que evoluíram para a forma clínica sintomática da doença.

Adicionalmente, foi feita uma correspondência manual entre os casos de LVH notificados para o Sistema Nacional de Agravos de Notificação (SINAN) do DF e os indivíduos que com a IDRM positiva em 2007 no intuito de se detectar a evolução para a doença entre os indivíduos assintomáticos.

\section{Análise dos dados}

Foi criada uma base de dados no programa SPSS 19.0 (IBM statistics) e as variáveis foram analisadas por meio de estatística descritiva.

\section{Aspectos éticos}

O estudo obedeceu às normas de pesquisas envolvendo seres humanos, com sigilo de informantes, termos de consentimento de todos participantes e aprovação do comitê de ética em pesquisa da fundação de ensino e pesquisa em Ciências da Saúde -FEPECS, Brasília/DF, (parecer 820.097). 


\section{RESULTADOS}

\section{Perfil social da população entrevistada no território endêmico}

Foram incluídos 120 sujeitos na pesquisa com IDRM positivo, 64 (53\%) do sexo masculino e 56 (47\%) do feminino. A idade dos entrevistados variou de 10 a 21 anos, com maior número de casos na faixa etária de 11 a 15 anos (55,8\%). No tocante à escolaridade, 90 (75\%) dos entrevistados possuíam ensino fundamental completo e $30(25 \%)$ apresentavam no máximo o ensino médio completo. Quanto à renda, 26 (21,7\%) dos entrevistados declararam ter renda familiar de até um salário mínimo e 94 (78,3\%) de um a três salários mínimos.

\section{Nível de conhecimento da população acerca da LVH}

A respeito do conhecimento da LVH na região, 75 (62,5\%) dos entrevistados afirmou não ter esclarecimentos, tampouco ter recebido informações acerca da doença. Em relação à transmissão, $20(16,7 \%)$ apontaram o inseto-vetor, reconhecido na região como mosquito palha, como a principal forma de transmissão da doença; e $25(20,8 \%)$ associaram a transmissão ao fato da presença de cães doentes na área em que vivem.

Quando questionados sob os principais sinais e/ou sintomas da doença, 75 (62,5\%) dos pacientes desconheceram os sintomas apresentados na entrevista, No entanto, 45 (37,5\%) dos entrevistados asseguravam ter informações e reconheceram os principais sinais e sintomas da doença, tais como febre 6 (5\%), emagrecimento 3 (2,5\%) e inchaço do fígado/baço 36 (30\%), conforme demonstrado na tabela 1.

Tabela 1. Principais sinais e sintomas da LVH reconhecidos pela população entrevistada

\begin{tabular}{lc} 
Inchaço do fígado/baço & $30,0 \%$ \\
Febre irregular & $5,0 \%$ \\
Perda ponderal & $2,5 \%$ \\
Desconhecimentos dos sintomas & $62,5 \%$ \\
\hline
\end{tabular}

Fonte: Dados da Pesquisa

\section{Presença de cães domésticos na área de estudo}

Dos entrevistados, $65(54,1 \%)$ possuíam até três cães domésticos em suas residências e $53(44,1 \%)$ afirmaram não possuir cães ou outros animais domésticos nesses locais. Além disso, detectou-se ainda que $6(5 \%)$ dos entrevistados afirmaram que um de seus animais foi encaminhado ao Centro de Controle de Zoonoses (CCZ) em decorrência da positividade para a LV. 


\begin{tabular}{lc}
\hline Mais de três cães domésticos & $1,8 \%$ \\
Até três cães domésticos & $54,1 \%$ \\
Inexistência de cães nas moradias & $44,1 \%$ \\
\hline Fonte: Dados da Pesquisa
\end{tabular}

Fonte: Dados da Pesquisa

\section{Análise das condições ambientais da região}

Em relação às condições ambientais, 111 (92,5\%) asseguram a existência de coleta e a disposição adequada de lixo nas comunidades. Em relação ao fornecimento de água, 66 (55\%) dos entrevistados afirmaram que as comunidades são abastecidas com água da rede pública, enquanto $54(45 \%)$ dos residentes referiram à utilização de poços artesianos para consumo doméstico.

Tabela 3.Condições ambientais da região

Coleta, transporte e destinação final do lixo $92,5 \%$

Abastecimento de água pela rede pública $55 \%$

Utilização de poços artesianos $45 \%$

Falta de saneamento básico $88,3 \%$

Precariedade do atendimento público de saúde $77,5 \%$

Proximidade das residências a áreas de vegetação local $55 \%$ Fonte: Dados da Pesquisa

\section{Evolução de casos assintomáticos de LVH com IDRM positivo}

Nenhum dos pacientes entrevistados referiu aparecimento de doença até o momento da entrevista, no entanto, a correspondência com a base de dados do SINAN-DF demonstrou que somente um dos indivíduos com IDRM positivo (sexo feminino) evoluiu para a forma subclínica da doença com a apresentação de sintomas discretos (febre, perda ponderal e fraqueza) e que não foi encontrado durante a realização das entrevistas.

\section{Discussão}

No Brasil, a LVH apresenta-se em expansão apesar das medidas e a existência de programas de controle. O Distrito Federal se encontra em área de transmissão da doença sendo notificados cerca de 50 casos por ano (SINAN). ${ }^{13}$ A maior parte deles se concentra na região estudada $(12 \%)$. 
Apesar do DF registrar casos em ambos os sexos e em todas as faixas etárias, constatou-se no estudo a predominância da doença em indivíduos do sexo masculino e em menores de 15 anos. A literatura aponta que a LVH pode ocorrer em ambos os sexos, entretanto, o masculino é descrito como o mais susceptível a doença. ${ }^{11,14,15,16}$ Os dados da pesquisa também corroboram com um estudo realizado em São Luís/MA, no qual foi registrada a ocorrência da LV em indivíduos com baixa idade. ${ }^{11,17,18}$

A Fercal é uma região com características típicas de zona rural, o que denota um caráter tipicamente silvestre-rural da doença. Considerada uma das áreas mais pobres do DF, a região se desenvolveu a partir da instalação de duas fábricas de cimento na década de 80 causando a ocupação irregular do solo com consequente desequilíbrio ambiental. Em busca de ocupações, várias famílias se alojaram nesse local, resultando em uma migração excessiva e consequente crescimento desordenado da área. Estudo recente aponta que o fluxo desordenado da população é um dos fatores queexplicam a introdução da doença nessa área. ${ }^{19}$ Para tanto, a LV além de ser uma doença ligada à pobreza, também a perpetua. ${ }^{20,21}$

A falta de saneamento e a proximidade das residências a vegetação local são reconhecidas como os principais problemas da região, sendo consideradas nesse âmbito, por atrair o vetor e ou reservatórios selvagens ao peri domicilio, contribuindo dessa forma para o aumento do risco de infecção das populações humanas e caninas susceptíveis. ${ }^{22}$

Estudos apontam que a proximidade das residências com a vegetação, a criação de animais e o acúmulo de matéria orgânica no local, estimulam a domiciliação do L. longipalpis. ${ }^{19}$

Tendo em vista a expansão urbana, o desmatamento ambiental no DF é considerado com um dos fatores relevantes para alteração do ambiente. Com isso, as residências têm se tornado cada vez mais próxima com áreas remanescentes do cerrado e permitindo a intercomunicação entres ciclos silvestre e urbano da doença.

Esses fatores podem ser determinantes para uma mudança no padrão de transmissão da doença, permitindo a sua urbanização, conforme registrado nas principais capitais brasileiras e também em outros países. A análise da epidemia de LVH e canina em Belo Horizonte-BH, são explicadas ao considerar o desequilíbrio ambiental pelo desmatamento, a migração e a urbanização desenfreada como relevantes para a instalação da doença no Munícipio. No DF, os registros de casos em áreas urbanas sugerem essa alteração no padrão de transmissão da doença. $^{18,21,23,24,25}$ 
Adicionalmente, a precariedade da assistência à saúde aponta falências em um dos pilares das estratégias de controle orientadas aos casos de $\mathrm{LVH}$, como o diagnóstico e o tratamento precoce, sendo demontrado, dessa forma uma descontinuidade no acompanhamento desses indivíduos diagnosticados pelos profissionais de saúde pertencentes às Unidades Básicas de Saúde local. Esses dados sinalizam a necessidade de reorganização do sistema de saúde local para que essas unidades funcionem como porta de entrada aos usuários do Sistema Único de Saúde-SUS. ${ }^{26}$

A pesquisa apontou um elevado número de cães nas residências da região. Esses resultados corroboram com as observações apontadas em pesquisa ${ }^{27}$ a qual revela que a região de Sobradinho, comparada às demais do DF, apresenta o maior número de casos confirmados de LVC. Estudos semelhantes ${ }^{28}$ apontam a maior incidência do vetor nessa região, com 9,4\% das espécimes coletadas e também o registro de casos humanos.

Estudos na Europa a respeito da prevalência da LVC estimam que, em áreas endêmicas, 2,5 milhões de cães estejam infectados. Em relação ao Brasil, a doença alcança uma prevalência 4 a $75 \%$ dependendo da área avaliada. ${ }^{29} 30$ Apesar de parcela dos participantes apontarem a inexistência de cães, o território endêmico é caracterizado um número elevado de cães residências, e, além deste fato, verificou-se dificuldades operacionais na implementação de ações de vigilância epidemiológica no local, uma vez que um baixo percentual de entrevistados apontou a aplicação de ações de controle canino, como a retirada do cão das residências e eliminação de soropositivos da área.

Sob o ponto de vista epidemiológico, o cão doméstico é considerado um reservatório de grande importância para a transmissão da LVH, sendo por esta razão, um dos alvos dos programas de controle da doença. Nesse contexto, estudos ${ }^{25}$ destacam a importância da realização de inquéritos sorológicos e a eliminação de cães soropositivos de áreas endêmicas, principalmente pelo fato dos casos caninos antecederem a casos humanos. Discute-se a alta prevalência de cães assintomáticos, e a importância do cão de fonte de infecção para o vetor e para o homem. Esses animais assintomáticos podem chegar a $80 \%$ da população infectada. ${ }^{31}$

Observou-se ainda que a população entrevistada apresentou um baixo nível de conhecimento acerca da LVH. Esse achado corrobora com um estudo ${ }^{32}$ no qual se avaliou o conhecimento da doença e a importância de atitudes preventivas da população em Belo Horizonte. Para os autores, a precariedade de informação sob a doença é relevante para sua manutenção em uma área endêmica. Neste contexto, os autores aventam a necessidade da realização de práticas educativas multidisciplinares, com a participação de médicos e 
veterinários, durante consultas e também de professores e agentes de saúde durante as visitas domiciliares.

O exíguo conhecimento acerca do vetor e sintomas da doença está de acordo com estudos realizados em Belo Horizonte, ${ }^{33}$ durante a avaliação do potencial dos folhetos de informação sob a LV para profissionais de saúde e leigos, foi discutido o desconhecimento e confundimento no que se refere à LV.

Vários autores identificam os fatores de riscos apresentados neste estudo como favoráveis à manutenção de indivíduos assintomáticos em áreas endêmicas. No diagnóstico, a positividade do IDRM é um indicador desses indivíduos em resposta à hipersensibilidade tardia, com a participação de linfócitos T e B e ativação de macrófagos. ${ }^{17,}{ }^{34}$ Neste contexto, sugere-se o acompanhamento desses indivíduos para se estabelecer parâmetros da força de infecção em um território endêmico.

A progressão para a doença de indivíduos assintomáticos na LV zoonótica ainda é tema controverso, sendo ainda desconhecida a importância destes para a transmissão da doença. Neste estudo evidenciou-se que quase a totalidade dos pesquisados comprovadamente positivos para a IDRM, não evoluiu para a doença após cerca de seis anos do diagnóstico.

Conclui-se, portanto, que o entendimento da progressão da LVH em um território endêmico não depende apenas da confirmação de pacientes assintomáticos por testes diagnósticos, como o IDRM, e sim da compreensão acerca da dinâmica de transmissão da doença: a circulação da L. chagasi, do vetor e a participação de determinados reservatórios no território. Por essa razão, é necessário que os inquéritos façam parte da atenção em saúde em áreas endêmicas, assim como o acompanhamento desses pacientes por um longo período a fim de analisar os fatores que possivelmente influenciam na evolução da doença.

\section{Referências}

1. Organization WH. Investing to overcome the global impact of neglected tropical diseases: third WHO report on neglected diseases 2015. Geneva: WHO Press; 2015.

2. Alvar J, Vélez ID, Bern C, Herrero M, Desjeux P,Cano J, et al. Leishmaniasis worldwide and global estimates of its incidence. PLoS One. 2012; 7(5): e35671.

3. de Almeida PS, de Andrade AJ, Sciamarelli A, Raizer J, Menegatti AJ, Hermes SC, de Carvalho Mdo S, Gurgel-Gonçalves R. Geographic distribution of phlebotominae sandfly species (Diptera:Psychodidae) in Central-West Brazil. Memo. Inst. Oswaldo Cruz, Rio de Janeiro: 1-9, 2015. 
4. Brasil. Ministério da Saúde. Manual de Vigilância e Controle da Leishmaniose visceral. Brasília: Ministério da Saúde, 2014.

5. de Melo EC, Fortaleza CM. Challenges in the therapy of visceral Leishmaniasis in Brazil: a public health perspective. J Trop Med. 2013; 2013: 319234.

6. Gontijo CMF, Melo MN. Leishmaniose Visceral no Brasil: Quadro atual, Desafios e perspectivas. Rev Bras de Epidemiol. 2004; 7(3): 338-49. DOI: 10.1590/S1415790X2004000300011.

7. Badaró R, Carvalho EM, Orge MGO, Teixeira RS, Rocha H. Imunidade humoral e celular em indivíduos curados de leishmaniose visceral. Revista da Sociedade Brasileira de Medicina Tropical. 1985; 18:77-83.

8. Caldas. AMJ, Aquino DMC, Ferreira NV, da Silva MAP, da Silva EL, Costa ASA, et al. Avaliação imunológica da intradermoreação de Montenegro. Rev. pesq. Saúde. 2010; 11(2): 9-13.

9. Babuadze G, Alvar J, Argaw D, de Koning HP, Iosava M, Kekelidze M, et al. Epidemiology of Visceral Leishmaniasis in Geórgia. PLoS Negl Trop Dis. 2014 Mar; 8(3): e2725.

10. Oliveira ALL, Paniago AMM, Sanches MA, Dorval MEC, Oshiro ET, Leal CRB, et al. Asymptomatic infection in family contacts of patients with human visceral Leishmaniasis in Três Lagoas, Mato Grosso do Sul State, Brazil.Cad Saude Publica 2008; 24:2827-2833.

11. Barão CS, de Fonseca Camargo-Neves VL, Resende RM, da Silva LJ. Human Asymptomatic infection in Visceral Leishmaniasis: A seroprevalence study in Urban Area of Low Endemicity. Preliminary results. Am J Trop Med Hyg. 2007 Dec;77(6):1051-3.

12. Pesquisa Distrital por Amostra de Domicílios [acesso em 15 jan 2015] Disponível em: http://www.codeplan.df.gov.br/images/CODEPLAN/PDF/Pesquisas\%20Socioecon\%C3\%B4 micas/PDAD/2012/PDAD-DF-2011-091112.pdf

13. Brasil. Ministério da Saúde. Secretaria de Vigilância à Saúde - Sistema de informação de Agravos e Notificação - SINAN. [acesso em 10 jan 2015]. Disponível em: www.saude.gov.br/sinanweb.

14. Ortiz CR, Anversa L. Epidemiologia da Leishmaniose visceral, São Paulo, no período de 2004 a 2012: um estudo descritivo. Epidemiol. Serv. Saúde. 2015; 24(1): 97-104. DOI: $10.5123 /$ S1679-49742015000100011

15. Cavalcante MJI, Vale RM. Aspectos epidemiológicos da Leishmaniose Visceral (calazar) no Ceará. Rev Bras Epidemiol. 2014; 17 (4): 911-924.

16. Pastorino AC, Jacob CMA, Oselka GW, Carneiro-Sampaio MMS. Leishmaniose Visceral: aspectos clínicos e laboratoriais. Jornal de ediatria. 2002; 78(2).

17. Hamdi S, Faouzi A, Ejghal R, Laamrani A, Amarouch H, Massar M, et.al. Socioeconomic and environmental factors associatedwith Montenegro skin test positiy in na 
endemic área of visceral Leishmaniasis in Nortern Morocco. Microbiology Reserch. 2012; 3 e-7.

18. Brasil. Distrito Federal. Secretaria do Estado de Saúde. Diretoria de Vigilância Epidemiológica. Informativo Epidemiológico das Leishmanioses no DF. Ano 07, no 3. Julho de 2015. [acesso em 10 mai 2015]. Disponível em <http://www.saude.df.gov.br/images/Leishmaniose/2015/Informativo_Epidemiologico_Leish manioses_DF_3_2015>.

19. Carranza-Tamayo CO, Carvalho MSL, Bredt A, Bofil MIR, Rodrigues RMB, Silva AD, et al. Autochthonous visceral Leishmaniasis in Brasília, Federal District, Brazil. Rev Soc Bras Med Trop 2010; 43:396-399.

20. Alvar J, Yactayo S, Bern C. Leishmaniasis and poverty. Trends Parasitol. 2006; 22: 552557.

21. Werneck GL. Visceral Leishmaniasis in Brazil: rationale and concern related to reservoir control. Rev Saude Publica. 2014; 48(5): 851-6. DOI: 10.1590/S0034-8910.2014048005615.

22. Victora CG, Barreto ML, Leal MC, Monteiro CA, Schimidt MI, Paim JS, et al. Condições de Saúde nas políticas de Saúde no Brasil: o caminho a percorrer. THE LANCET. 2011 maio. p.90-102.

23. Bevilacqua PD, Paixão HH, Castro MCPS, Modena CM. Leishmaniose Visceral: história Jornalística de uma epidemia em Belo Horizonte, Brasil. Interface-Comunicação, Saúde, Educação. 2000; 4 (7): 82-102.

24. Costa $\mathrm{CH}$. Characterization and speculations on the urbanization of visceral Leishmaniasis in Brazil. Cad. Saude Publica. 2008; 24(12): 2959-63.

25. Alves WA, Bevilacqua PD. Reflexões sobre a qualidade do diagnóstico da leishmaniose visceral canina em inquéritos epidemiológicos: o caso da epidemia de Belo Horizonte, Minas Gerais, Brasil, 1993-1997. Cad Saude Publica 2004; 20:259-265.

26. Barbosa IR. Epidemiologia da Leishmaniose Visceral no Estado do Rio Grande do Norte, Brasil. Revista de Epidemiologia e Controle e infecção. 2013 (v.3).

27. Herenio EM, Fortes RC, Rincon G. Prevalência daLeishmaniose visceral em cães do Distrito Federal, segundo dados do Centro de Zoonoses de Brasília. Jounal Sci. Inst. 2014; 32(2).

28. Carvalho MS, Bredt A, Meneguin ER, Oliveira C. Flebotomíneos (Diptera: Psychodidae) em áreas de ocorrência de leishmaniose tegumentar americana no Distrito Federal, Brasil, 2006 a 2008. Epidemiol Serv Saúde. 2010;19(3): 227-37.

29. Marcondes M, Rossi CN. Leishmaniose Visceral no Brasil. Braz. J. Vet. Res. Anim. Sci. 2013; 50(5).

30. Dantas-Torres F, Brito ME, Brandao-Filho SP. Seroepidemiological survey on canine Leishmaniasis among dogs from an urban area of Brazil. Vet Parasitol 2006; 140:54-60. 
31. Dantas-torres F. Leishmania infantum versus Leishmania chagasi: do not forget the law of priority. Mem. Inst. Oswaldo Cruz. 2006. V. 101 (1):117-118.

32. Borges BKA, da Silva JA, Haddad JPA, Moreira EC, de Magalhães DF, Ribeiro LML, et. al. Avaliação do nível do conhecimento e de atitudes preventivas da população sobre a Leishmaniose Visceral em Belo Horizonte, Minas Gerais do Brasil. Cad Saude Publica. 2008;24(4).

33. Luz ZM, Schall V, Rabello A. Evaluation of a pamphlet on visceral Leishmaniasis as a tool for providing disease information to healthcare professionals and laypersons. Cad Saude Publica. 2005; 21: 606-621.

34. Caldas AJM, Silva DRC, Pereira CCR, Nunes PM, Silva BP, Silva AAM, Barral A, Costa JML. Infecção por Leishmania (Leishmania) chagasi em crianças de uma área endêmica de leishmaniose visceral americana na Ilha de São Luiz- MA, Brasil. Revista da Sociedade Brasileira de Medicina Tropical 34: 445-451, $2001 \mathrm{~b}$. 
ARTIGO 4: Visceral Leishmaniasis epidemiologic evolution in timeframes based on demographic changes and scientific achievements in Brazil

Artigo aceito para publicação, segundo as normas da Revista Journal of Vector Borne Disease, em 29 de dezembro de 2015. 


\title{
Visceral Leishmaniasis epidemiologic evolution in timeframes based on demographic changes and scientific achievements in Brazil
}

\author{
Renata Vivas Conti ${ }^{\mathrm{a}}$, Viviane Fragoso Moura Lane ${ }^{\mathrm{b}}$, Lucia Montebello ${ }^{\mathrm{c}}$, Vitor Laerte Pinto \\ Junior $^{\mathrm{d}, \mathrm{e}}$. \\ a - Sobradinho Regional Hospital, Brasília, Brazil. \\ b- Health Sciences Post-graduation Program, University of Brasília, Brazil. \\ c- Brazilian Ministry of Health, Brasília, Brazil. \\ d-Oswaldo Cruz Foundation, Brasília, Brazil. \\ e- Hygiene and Tropical Medicine Institute, New University of Lisbon, Portugal.
}

\section{Resumo}

A Leishmaniose Visceral (LV) é uma doença de evolução crônica geralmente fatal se não tratada. A LV humana foi descrita pela primeira vez nas Américas em 1913 e no Brasil em 1936. Atualmente, o número de casos no Brasil encontra-se em plena expansão com aumento progressivo nas últimas três décadas. Tem se associado este aumento a uma mudança da epidemiologia da doença que estaria "urbanizado-se", já que a maior parte dos casos vem ocorrendo em grandes cidades diferentemente do que anteriormente era observado, uma endemia tipicamente rural. O objetivo deste estudo foi criar uma narrativa histórica da epidemiologia da doença agregando informações que possam criar hipóteses para explicar a sua consolidação como endemia urbana e contribuir para a discussão de medidas de controle mais efetivas. Para a tentativa de se explicar o processo de urbanização da leishmaniose, os autores estabeleceram períodos em que houvesse certa consistência histórica entre os conhecimentos alcançados acerca da LV e as características demográficas do Brasil, principalmente considerando-se os grandes movimentos migratórios ocorridos no País em decorrência de fatos políticos ou económicos. A primeira fase da LV foi delimitada da década de 1930 - 50 quando a industrialização iniciou processo de migração interna do campo para as cidades e a LV foi estudada pela primeira vez descrevendo-a como epidemia rural sem importância para a saúde pública. Até a segunda fase, entre as décadas de 1950 e 1980 caracterizou-se por ampliação da imigração para os grandes centros e do adensamento populacional nas periferias com baixas condições de vida. Nesta ocasião aprimora-se o conhecimento da transmissão da LV e descreve-se os primeiros casos adquiridos no ambiente urbano. A terceira fase, de 1980 até os dias atuais, caracteriza-se pela explosão dos casos em 
cidades brasileira e a consolidação da endemia urbana. A possibilidade de transmissão urbana é conhecida desde a década de 1950 e o fenômeno atual deveu-se a criação de condições ideais para a manutenção do ciclo de transmissão nas cidades brasileiras.

Palavras-chave: Leishmaniose visceral, epidemiologia, urbanização.

\begin{abstract}
Visceral Leishmaniasis (VL) is a disease of chronic evolution uniformly fatal disease if untreated. The VL was first described in the Americas in 1913 and in 1936 in Brazil. Currently, the number of VL cases in Brazil is booming with a gradual increase in the last three decades. Linked to this increase is the change in the epidemiology of the disease that would be "urbanizing" since most of the cases has occurred in large cities differently than was previously noted, a typical rural endemic. The aim of this study was to create a historical narrative of the epidemiology of the disease aggregating information that might create an hypotheses to explain its consolidation as urban endemic and contribute to the discussion of more effective control measures. To attempt to explain the process of urbanization of VL, the authors created periods when there were certain historical consistency between the knowledge obtained about the VL and the demographics of Brazil, especially considering the great migratory movements in the country due political or economic events. The first phase of VL was defined the decade 30-50 when industrialization began internal migration process from countryside to the cities during this period VL was for the first time studied and was described as a rural endemic with no relevance to public health. Until the second phase, between the 50 and 80 was characterized by expansion of immigration to the large cities and increasing population density in the suburbs with low living standards. In this period there is an improvement in the knowledge of the transmission of VL and describes the first cases acquired in the urban environment. The third phase is characterized by the explosion of cases in Brazilian cities and consolidation of urban endemic. The possibility of urban transmission has been known since the 50s, the current phenomenon was due to the creation of ideal conditions for maintaining the transmission cycle in Brazilian cities.
\end{abstract}

Keywords: Visceral Leishmaniasis, epidemiology, urbanization. 


\section{Introduction}

Visceral Leishmaniasis (VL) is an endemic disease with a complex clinical course, usually fatal if left untreated. According to the World Health Organization (WHO), it is considered a neglected and emerging disease endemic in 98 countries with $90 \%$ of cases concentrating in Bangladesh, Nepal, Sudan, India and Brazil. In 2010 there were a total of 200 million people at risk of acquiring the disease, about 300,000 new cases were registered and between 20,000 to 50,000 deaths occurred annually in the World $(1,2)$.

LV in Brazil is a zoonosis caused by Leishmania infantum (syn chagasi) and transmitted namely by Phlebotominae females of Lutzomya longipalpis species. Two cycles of disease transmission are described, a sylvatic, mainly maintained by wild foxes (Vetulus pseudalopex and Dusicyon thous) and other domestic, whose main reservoir is the dog (Canis familiaris). In both transmission cycles man is regarded as an accidental host, since so far human infection was not proved to be able to maintain the transmission $(3,4)$.

The first case of VL in the Americas was first diagnosed in 1913 by a Paraguayan doctor at Assumption from a patient coming from the city of Corumbá in Brazil (5). Only in 1934, Penna reports the presence of Leishman-Donovan bodies in 41 tissue specimens analyzed in histopathological examination from post-mortem viscerotomies performed on diseased persons suspected of yellow fever infection coming from the North, Northeast and Southeast regions of Brazil (6).

Currently, the number of cases of human VL in Brazil is evolving to a slope increase in the last three decades (7). This growth has been associated to changes in the disease epidemiology during this time span and the phenomena has been called as disease urbanization since most of the cases has occurred in large cities in contrast to the typically rural endemic as previously believed $(8,9)$. The objective of this study was to elaborate a proposal to systematize the evolution of VL in Brazil through narrative review aggregating information that might create hypotheses to explain its consolidation as urban endemic and contribute to the discussion of more effective control measures.

\section{Materials and methods}

We have done a narrative review based on articles published about LV held in Brazil since its first description postmortem case in 1934 by Penna (6). Demographic information 
was obtained on the website of the Brazilian Institute of Geography and Statistics (IBGE), especially the section of statistics and historical series (http://www.seriesestatisticas.ibge.gov.br/).

To attempt to explain the process of urbanization of Leishmaniasis, the authors established timeframes with certain historical concordance between the scientific knowledge obtained on VL and the demographic characteristics of the population at the time, especially considering the great migratory movements in Brazil as a result of political or economic events (10).

The first period considered in the study was the decade from 1930 to 1950 , when the New State (Estado Novo) consolidates the process of industrialization of the country mainly concentrated in the southeast region and when the intense internal migration movements accompanied a vegetative growth of the population. On that occasion VL is described for the first time in Brazil and its clinical and epidemiological characteristics started to be investigated.

The second period ranges from 1950 to 1980 and is characterized by greater dynamism of industrialization with initial consolidation of the new production poles and the creation of others, and also associated with the industrialization of agriculture activity. In this period occur the greatest migration movements of citizens from the countryside to urban zones. The consequence is that from the 1960s the proportion of the urban population surpasses the proportion of individuals living in the countryside (11). The knowledge on VL transmission dynamics settles down with the definition of the role of the wild reservoir and the vector, the phlebotminae L. longipalpis, and the description of the first cases of urban origin (12).

From the 1980s there was a shift in the Brazilian migration process; after consolidation, urbanization continues to expand to new agricultural zones in the north of the country. The urbanization process in Brazil culminated in the concentration of population in peripheral areas of the cities with poor sanitation conditions. The emergence of urban epidemics of LV are detected in several important cities countrywide and the total number of cases increases steadily. This timeframe is marked epidemiologically by disease urbanization and exposes the failure of control measures executed under the responsibility of the Ministry of Health and municipalities. 
Fonte - IBGE/Brasil

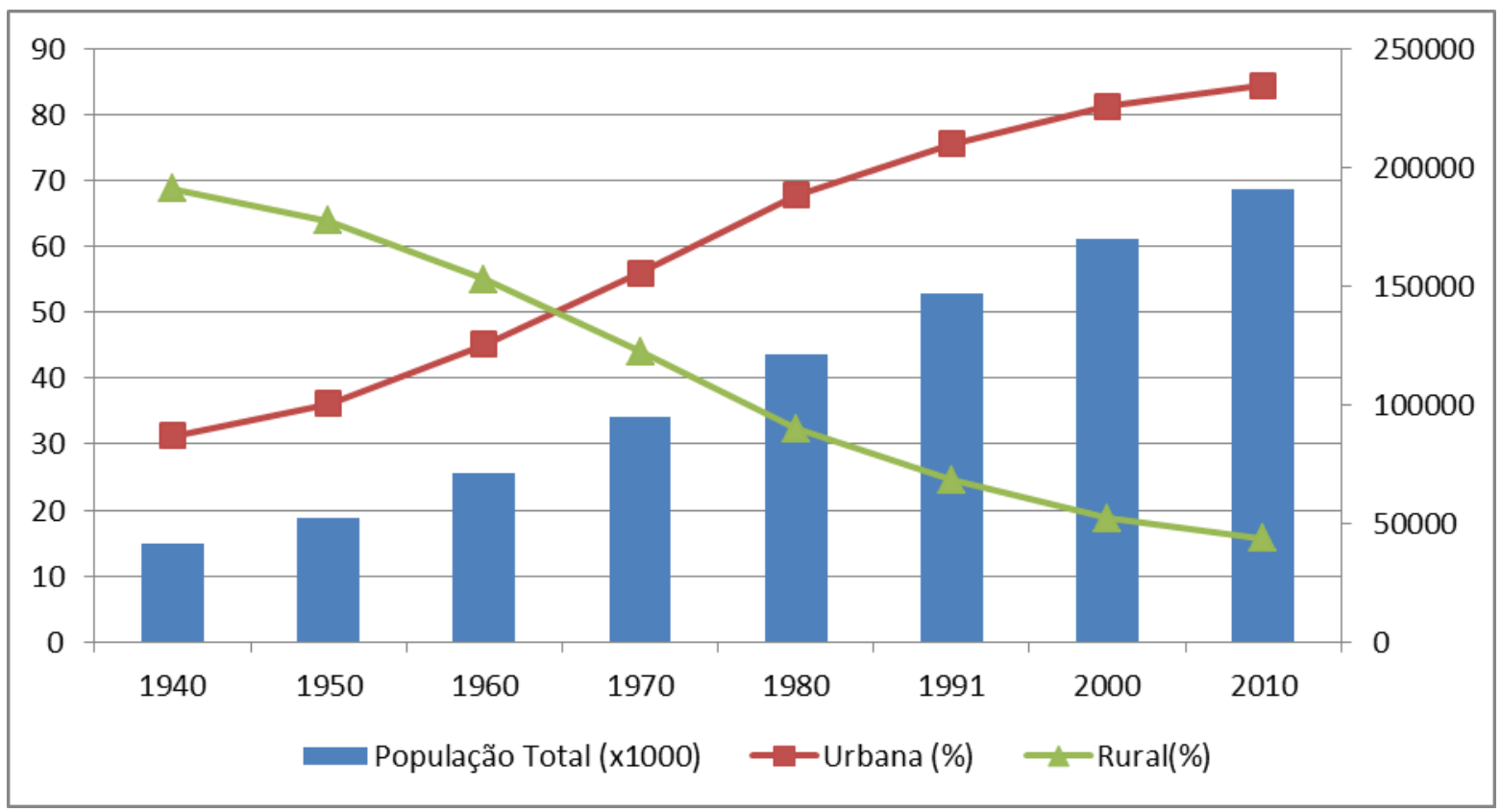

Figure 2 - Brazilian population census from the 1940 and the proportion of population living in urban and rural areas.

First period of VL in Brazil - sparse rural cases without public health concern (Decade 30 to mid-1950).

The population census conducted in 1940 shows a population of about 40 million people passing the 52 million people in the 1950s. Since the early twentieth century, the population had increased both as a result of fertility and trough the immigration from foreign countries with an input of three million immigrants including Portuguese, Italian and other European nationalities.

During this period most of the population lives in rural areas and are employed in commodity agricultural activities (coffee plantation was the motor activity of the economy at the time). The 1929 global crisis has an impact on the Brazilian economy primarily by the breakdown of the coffee market and fostered the beginning of a new cycle of industrialization having as centers the city of São Paulo and Guanabara (now the city of Rio de Janeiro). The internal migration of individuals from rural areas and small towns for these urban centers reached four million people at the end of the 40s.

In 1936, Evandro Chagas and his "Committee charged on American Visceral Leishmaniasis studies" described the first alive case of VL in Brazil in a boy of 16 years-old, 
brother of another case died from the disease and whose histopathological analysis of viscerotomy specimen had been given as positive for Penna in 1934 (13).

The Committee performed medical assessment of all individuals who inhabited households with cases of the disease documented by histopathological analysis and the greatest possible number of individuals who lived around the areas with documented outbreaks, insect, domestic and wild mammals capture for analysis of the presence the parasite. $(14,15)$. Despite that, the Committee found the disease in a few patients and the infection in eight domestic animals (seven dogs and a cat). Thus, the researchers concluded that it was a restricted disease to rural areas surrounded by remaining forest and epidemiological characterized by sporadic transmission.

Chagas also suggested the role of wild animals in the transmission cycle, regarding them as the main reservoirs, and excluded the participation of man and the domestic dog in the maintenance of the disease in man. Also associated sandflies insects, among the various species of insects found, as vectors of the disease, despite not having been able to establish this relationship unequivocally.

Indeed, the conclusions of the Committee established the theoretical foundations that have influenced public health actions and research of the disease in the following decades until the present day. However, for about two decades, VL was considered a disease of no importance from the health point of view only causing sporadic cases in regions with low population density and far from major centers. Only in the 1950s that medical reports from the city of Sobral, Ceará state, through the detection of an abnormally high number of cases, alerted the scientific community that VL could have a different epidemiology than was believed.

\section{Second period of the VL in Brazil - The establishment of rural endemic}

Until the early 50s VL was considered a medical curiosity in Brazil, just over 40 cases were diagnosed and 240 histopathological examination of viscerotomies specimen were positive for more than a decade (12).

However, the frequent diagnosis of Northeastern immigrants with VL met in large centers like the University of São Paulo's Hospital, in 1954 (16) and clinical communications from Ceará state reporting the existence of several cases from 1953, made Deane and 
colleagues, a member of the formely Evandro Chagas Committee, went to the city of Sobral to conduct further investigation about the situation of the disease between 1953 and 1954.

In Sobral, during the period of a few months, they found 188 cases of VL, more than the quadruple diagnosed countrywide at the time. Of which was possible to carry out the investigation of 177 cases with respect their clinical and epidemiological characteristics. Deane and Deane were able to modify the existing paradigm about the disease so far. Among its findings are: the first description of wild reservoir, the canid species Lycalopex vetulus; the role of the domestic dog as the main source of infection; and the sand fly L. longipalpis as the main vector of the disease (17).

The excellent description of the distribution of the cases in relation to the environment where they acquired the disease demonstrated the importance of vector density in disease transmission. Also it was found that three percent of cases were acquired in the urban environment, contrasting to what Chagas and collaborators previously stated that VL was an exclusively rural disease.

Most of the diagnosed cases were children 0-9 years, this finding were reinforced by the report by local physicians and residents of previously epidemics of a disease with a clinical picture similar to VL which killed great part of children. This observation posed the hypothesis that this disease presented itself as endemic interspersed with epidemic cycles with high morbidity and mortality among children.

The work of Deane and Deane anticipated the possibility of urbanization of the disease, a fact that would only become a public health problem 30 years later(18). Additionally put VL among the health priorities of the country when demonstrated that it was not a disease with sporadic occurrence, but an endemic disease predominantly rural at time, but with potential for urbanization and of great social impact; these conclusions took the Ministry Health to create a national disease control program (19).

This timeframe is marked, from the demographic point of view, by population vegetative increase and an huge rural exodus towards the large cities. It is reported that in the 1960s have moved more than 11 million people toward the urban centers with greater power of attraction as a result of the industrialization process. It is also in the 1960s that the proportion of individuals living in cities exceeded those living in the countryside (Graph 1) (11). 
Since then, new cases were detected in various states of the Northeast, especially Piauí, Bahia and Pernambuco. Sporadic cases have also been reported in Goiás and Mato Grosso and Mato Grosso do Sul in the Central West Region (20-22).

In the 1970s, the rural region of Vale do Rio Doce, Minas Gerais, has become endemic, preceding the establishment of urban VL in the capital Belo Horizonte in the next decade, but government actions to control seemingly quelled the outbreak (23).

\section{Third period of VL in Brazil - 1980s and the consolidation of disease urbanization.}

Since the 1950s, the VL was treated as rural endemic, control measures were applied discontinuously aiming vector and domestic reservoir control, with prioritization of rural areas (19). From the second half of the 1970 urban areas, especially in large cities, have received large numbers of people from rural areas due to environmental conditions (a large impact event were the successive droughts in the Northeast) and unfavorable social conjecture. At the same time there was a significant vegetative increase in the population of urban areas from the decade of 1960. The last population census in 2010 revealed that the proportion of the population in these areas reached $85 \%$ of the total population (Figure 1).

In the Southeast, the states of Minas Gerais, Rio de Janeiro and Espirito Santo, from the 1980s began to show major outbreaks of disease, away from the old endemic areas of the Northeast.

In the city of Rio de Janeiro, beginning in late 1970 and extending for the years 1980-90, there were dozens of cases of human VL and hundreds of canine VL in peri-urban and urban areas of the city, at which time measures were also adopted that managed to control the occurrence of new human cases (24).

Until 1990 it was reported 53480 cases of VL in Brazil and the northeast region accounts for $90 \%$ of them (7). In 1981 he was caught an VL epidemic in Piauí state capital being notified 1059 cases in a period of six years and focusing on the period of 190 cases / 100.00 inhabitants (25). There were also outbreaks in São Luís (capital of Maranhão), Belo Horizonte (capital of Minas Gerais), Campo Grande (Mato Grosso do Sul capital) among other large cities (26-28).

Between 1998 and 2005, information taken from the National Notifiable Diseases System (SINAN), showed that VL was detected in $34.2 \%$ of Brazilian municipalities with an 
average fatality rate of 5.5\%. The most affected age group was that of children under 10 years with the proportion of $56.7 \%$ of cases showing that in Brazil, despite the epidemiological changes, it is still a disease typically linked to childhood (18).

\section{Discussion and conclusions.}

The first evidence of the epidemiology of VL emerged from the analysis of the Evandro Chagas expedition to the North and Northeast of Brazil in 1936 (15). The fact that they found few cases exclusively in rural areas made them to conclude that it was an endemic disease of low impact and geographically restricted. These finds influenced public health actions for decades halting disease monitoring and control.

The few cases diagnosed in vivo countrywide from 1934 to 1955 may have resulted from the little interest raised by the disease and because of the unavailability of diagnostic methods at time. The fact is that the VL was considered a disease of purely academic interest in Brazil during this period, which halted the execution of an adequate response by the health authorities in the same intensity as carried out in the control of yellow fever.

Only two decades after the description of the first case in Brazil and four decades after the first description in South America, VL transmission its transmission dynamics almost completely described by Deane et al in 1955 (12). At this point these researchers demonstrated the existence of disease transmission in urban areas and that the main factors for the occurrence of the disease are the population concentration and favorable environmental conditions to "an exuberant proliferation of the transmitter".

As soon as the Brazilian sanitary authorities realized that VL actually was a public health problem due to their high morbidity and severity especially in children, the $\mathrm{MoH}$ created a department for disease control in the 1950s. Nevertheless the program was interrupted in the 1960s and only resuming its activities in the 1980s, yet with a high degree of discontinuity, even facing the worsening of the epidemiological situation of the country with the emergence of urban epidemics (19).

From the 1930s, internal migration from rural to urban areas displaced large populations to the newly industrializing cities, this phenomenon resulted that from the 1960s the proportion of inhabitants in urban areas exceeded to the countryside. This process did not find the necessary urban planning in order to accommodate this magnitude of people. The occupation of peripheral areas of the cities with high population density and the maintenance 
of habits linked to rural areas as breeding in backyards (like chickens and dogs) are considered factors that favored the establishment of the VL transmission cycle in the urban environment (11).

The establishment of urban epidemics of VL in Brazilian cities is described from the beginning of the 1980s. In 1981 the increase in the number of cases in the city of Teresina, Piauí alerted to the problem that until then was not considered as a priority, taking into account the extinction of control activities in the 1960s (25). From thereon the literature referred this process as the VL urbanization in Brazil. Nevertheless urban cases were detected earlier by Deane et al in Sobral, Ceará state, who also stated that the disease occurs followed by the presence of favorable conditions, which indeed were present in the majority of Brazilian big cities at time, and still do (12).

Negligence of disease control and for health and social problems caused by lack of planning in welcoming the immigrant population in cities resulted in achievement of the optimal conditions to the occurrence of high grade disease transmission country wide. In contrast, it was registered two successful experiences of effective control of an epidemics of rural VL in Vale do Rio Doce, Minas Gerais, in the 1970s and periurban / urban VL in Rio de Janeiro in the decades from 1980 to $2006(23,24)$.

Limitations of this review primarily are related to publication bias, although we have sought in major databases and libraries, we certainly were not able to include all the literature, especially those that are in thesis or book formats. However, the systematization of the evolution of the epidemiology of VL in Brazil in phases based on scientific and demographic landmarks appears to be unprecedented work and contributes to the analysis of timeframes when there was a failure in disease control.

The current complexity of the transmission mechanisms of urban VL represent new challenges and require new strategies and approaches for its control. Control programs should consider, besides factors as the faster movement of human populations and infected dogs, sources of infection and the greater dispersion of insect vectors, but also the social impacts of economic development of nations $(29,30)$.

The the control of VL in Brazil has no easy solution, current strategies are difficult to implement under current social and political conditions resulting in progressive increase in the number of cases and territorial expansion of the disease in the last 40 years (31). It is clear that intervening solely in disease transmission dynamics is not sufficient to achieve the control objective and that there is need to establish a minimally adequate urban planning in 
Brazilian cities allied to economic and social development $(30,32)$. Undoubtedly, sixty years of negligence in controlling the disease and uncontrolled and poor urban growth make the adoption of these "alternative" measures extremely costly and difficult to implement regarding the social and political impacts involved. However, this will be the price to be paid in order that not only the VL, but also other vector-borne diseases become real medical curiosities in the tropics.

\section{References}

1. Organization WH. Investing to overcome the global impact of neglected tropical diseases: third WHO report on neglected diseases 2015. Geneva: WHO Press; 2015.

2. Alvar J, Vélez ID, Bern C, Herrero M, Desjeux P, Cano J, et al. Leishmaniasis worldwide and global estimates of its incidence. PLoS One. 2012;7(5):e35671.

3. Lainson R. The American Leishmaniases: some observations on their ecology and epidemiology. Trans R Soc Trop Med Hyg. 1983;77(5):569-96.

4. Lainson R, Rangel EF. Lutzomyia longipalpis and the eco-epidemiology of American visceral Leishmaniasis, with particular reference to Brazil - A Review. Memórias do Instituto Oswaldo Cruz. 2005;100(8):811-27.

5. Oddone Costanzo R. Leishmaniosis visceral: a 101 años del primer caso diagnosticado en las Américas. Memorias del Instituto de Investigaciones en Ciencias de la Salud. 2012;10:100-4.

6. Penna H. Leishmaniose visceral no Brasil. Bras Med. 1934;18:940-50.

7. Gontijo CMF, Melo MN. Leishmaniose visceral no Brasil: quadro atual, desafios e perspectivas. Revista Brasileira de Epidemiologia. 2004;7:338-49.

8. Harhay MO, Olliaro PL, Costa DL, Costa CH. Urban parasitology: visceral Leishmaniasis in Brazil. Trends Parasitol. 2011;27(9):403-9.

9. Costa $\mathrm{CH}$. Characterization and speculations on the urbanization of visceral Leishmaniasis in Brazil. Cad Saude Publica. 2008;24(12):2959-63.

10. Martine G. As migrações de origen rural no Brasil: uma perspectiva histórica: Associação Brasileira de Estudos Populacionais; 1989.

11. Brito F. O deslocamento da população brasileira para as metrópoles. Estudos Avançados. 2006;20(57):221-36. 
12. Deane M, Deane L. Observações sobre a transmissão da leishmaniose visceral no Ceará. O Hospital. 1955;48(3):347-64.

13. Chagas E. Primeira verificação em indivíduo vivo da Leishmaniose visceral no Brasil. Brasil Médico. 1936;50:221.

14. Chagas E, Cunha A, Ferreira L, Guimarães F, Deane L, Deane G, et al. Leishmaniose visceral americana: relatório dos trabalhos da comissão

encarregada dos estudos da leishmaniose visceral americana em 1937. Memórias do Instituto Oswaldo Cruz. 1938;33(1).

15. Chagas E, Cunha A, Castro G, Ferreira L, Romana C. Leishmaniose visceral americana: relatório dos trabalhos da comissão encarregada dos estudos da leishmaniose visceral americana em 1936. Memórias do Instituto Oswaldo Cruz. 1937;32(3):321-85.

16. Veronesi R, Jamra M, Silva O, Cruz O, Fiorilo A. Leishmaniose visceral (kalaazar): Estudo do quadro clínico, hematológico e eletroforético. Rev Hosp Clin. 1954;9(1).

17. Deane L, Deane M. Encontro de Leishmanias nas vísceras e na pele de uma raposa, em zona endêmica de calazar, nos arredores de Sobral, Ceará. O Hospital. 1954;45(4):45-7.

18. Maia-Elkhoury AN, Alves WA, Sousa-Gomes ML, Sena JM, Luna EA. Visceral Leishmaniasis in Brazil: trends and challenges. Cad Saude Publica. 2008;24(12):2941-7.

19. Lacerda MM. The Brazilian Leishmaniasis Control Program. Mem Inst Oswaldo Cruz. 1994;89(3):489-95.

20. Vilela J, Luciano L, Rojas S. Novos casos de calazar autóctone nos estados de Goiás e Mato Grosso. O Hospital. 1966;69(2):403-14.

21. IA S. Surto de calazar na zona central do estado da Bahia. Rev Bras Mal D Trop. 1963;16:157-70.

22. D H. Calazar em Pernambuco. O Hospital. 1970;78(5/6):1345-57.

23. PA M, W M, CA dC, NM M, M D, SM B, et al. Calazar na Zona do Rio Doce - Minas Gerais. Resultados das medidas profiláticas. Revista do Instituto de Medicina Tropical de São Paulo. 1980;22(4):197-202.

24. Marzochi MCdA, Fagundes A, Andrade MVd, Souza MBd, Madeira MdF, Mouta-Confort E, et al. Visceral Leishmaniasis in Rio de Janeiro, Brazil: eco-epidemiological aspects and control. Revista da Sociedade Brasileira de Medicina Tropical. 2009;42(5):57080. 
25. Costa CH, Pereira HF, Araújo MV. [Visceral Leishmaniasis epidemic in the State of Piauí, Brazil, 1980-1986]. Rev Saude Publica. 1990;24(5):361-72.

26. Costa JM, Viana GM, Saldanha AC, Nascimento MD, Alvim AC, Burattini MN, et al. [Visceral Leishmaniasis in the State of Maranhão, Brazil: evolution of an epidemic]. Cad Saude Publica. 1995;11(2):321-4.

27. Silva ES, Gontijo CM, Pacheco RS, Fiuza VO, Brazil RP. Visceral Leishmaniasis in the Metropolitan Region of Belo Horizonte, State of Minas Gerais, Brazil. Mem Inst Oswaldo Cruz. 2001;96(3):285-91.

28. Oliveira AL, Paniago AM, Dorval ME, Oshiro ET, Leal CR, Sanches M, et al. [Emergent outbreak of visceral Leishmaniasis in Mato Grosso do Sul State]. Rev Soc Bras Med Trop. 2006;39(5):446-50.

29. MCA M, style="font-size:11.0pt s, line-height:115\%, font-family:"Calibri" s-s, mso-ascii-theme-font:minor-latin, mso-fareast-font-family:, et al. A questão do controle das leishmanioses no Brasil. In: Fiocruz E, editor. <span style="font-size:110pt;lineheight:115\%;

font-family:"Calibri","sans-serif";mso-ascii-theme-font:minor-latin;mso-fareast-fontfamily:

Calibri;mso-fareast-theme-font:minor-latin;mso-hansi-theme-font:minor-latin;

mso-bidi-font-family:"Times New Roman";mso-bidi-theme-font:minor-bidi; mso-ansi-language:PT-BR;mso-fareast-language:EN-US;mso-bidi-language:AR-

SA">Leishmanioses

do continente americano. Rio de Janeiro2014. p. 512 p.

30. Frieden TR. SHATTUCK LECTURE: The Future of Public Health. N Engl J Med. 2015;373(18):1748-54.

31. Barreto ML, Teixeira MG, Bastos FI, Ximenes RA, Barata RB, Rodrigues LC. Successes and failures in the control of infectious diseases in Brazil: social and environmental context, policies, interventions, and research needs. Lancet. 2011;377(9780):1877-89.

32. Ribas LM, Zaher VL, Shimozako HJ, Massad E. Estimating the optimal control of zoonotic visceral Leishmaniasis by the use of a mathematical model. ScientificWorldJournal. 2013;2013:810380. 


\section{CONCLUSÕES}

- Entre os períodos de 2005-2009, as capitais brasileiras de Belo Horizonte, Campo Grande, Fortaleza e Palmas, apresentaram um perfil hiperendêmico a LV. Constatouse que a análise de TAC's relativas ao controle da LV, limitava-se a interesses difusos consubstanciados nos direitos dos animais, com vistas a evitar os procedimentos de eutanásia considerados em determinados casos. Conclui-se, portanto, que esforços direcionados apenas no impedimento da eutanásia, são insuficientes para conter a expansão territorial da LV. Neste contexto, deverão ser comtemplados aspectos revelantes para a epidemiologia da doença, como as questões ambientais, o controle vetorial e a situação de saúde humana com a melhoria da atenção primária à saúde.

- Observou-se o reconhecimento dos profissionais que atuam na atenção primária à saúde sob a importância epidemiológica da LV no território endêmico, apesar das dificuldades operacionais enfrentadas nas UBS's para o diagnóstico precoce e tratamento da doença.

- Ao considerar a evolução clínica de pacientes com IDRM positivo, constatou-se a progressão de um caso assintomático para a forma subclínica da doença. Conclui-se, portanto, que o entendimento da dinâmica de transmissão da LV em um território endêmico, é relevante para o acompanhamento desses casos.

- Demonstrou-se que a possibilidade de transmissão urbana da LV é reconhecida desde a década de 1950. Tendo em vista as mudanças demográficas ocorridas no Brasil, nas últimas três décadas, concluiu-se que as cidades brasileiras propiciam a manutenção do ciclo de transmissão, e consequentemente, a LV urbanizada. 


\section{CONSIDERAÇÕES FINAIS}

Este trabalho se propôs a uma análise epidemiológica da LV no Brasil com abordagens direcionadas aos pilares de controle da doença, de modo a elaborar elementos que contribuam para a compreensão da expansão territorial da LV no país e o seu potencial em causar epidemias, principalmente nos centros urbanos.

A partir do perfil epidemiológico das principais capitais brasileiras analisadas no primeiro estudo, constatou-se o comportamento hiperendêmico da LV nos grandes centros ubanos brasileiros, o qual evidencia a falência das políticas de controle da LV. Além deste enfoque, considerou-se outro incurso, o envolvimento do Ministério Público nas atividades operacionais de controle do principal reservatório, a eutanásia de cães infectados, motivada por entidades não governamentais, principalmente ligadas à defesa do animal, ao acionarem o Ministério Público em atendimento ao interesse difuso. No entanto, questiona-se a efetividade desta medida, haja vista a falta de sustentabilidade do Poder Executivo em implementá-la. Portanto, aventam-se para uma judicialização das políticas de saúde harmoniosa, condicionadas às questões ambientais, principalmente a vetorial, adequação ao controle de reservatórios, e por fim, o fortalecimento das ações no nível primário de saúde. ${ }^{281}$

Ao preconizar o diagnóstico precoce e o tratamento adequado, evidencia-se a inclusão da atenção primária à saúde nas ações de controle da LV. Buscou-se, junto aos profissionais de saúde atuantes neste território endêmico, evidenciar a atenção primária nos casos de LV. Constataram-se dificuldades operacionais de ações e o desconhecimento das equipes de saúde a respeito da dinâmica de transmissão da doença no local. Tal fato reforça a fragilidade de outro pilar de controle da LV no Brasil. Tendo em vista a magnitude da doença, se discute a relevância deste nível atenção, uma vez que as ações estão voltadas para a prevenção e controle, o acesso à informação e o adequado acompanhamento dos casos com o correto diagnóstico. Entende-se, portanto, que o fortalecimento da atenção primária com a atuação efetiva dos profissionais de saúde é fulcral para as políticas de saúde pública. ${ }^{282}$

No intuito de analisar o comportamento de casos assintomáticos em um território endêmico a LV no DF, evidenciaram-se vários elementos que condicionam a manutenção da doença no local. Observou-se neste estudo, uma descontinuidade das ações de controle da LV, uma vez que não houve acompanhamento dos indívíduos residentes desta área pela atenção primária à saúde. Cabe ressaltar, que em áreas endêmicas a maior parte dos indivíduos é reconhecida como assintomáticos. Por essa razão, a exposição desses indíviduos a 
determinados fatores de riscos, podem dar suporte a estudos que visam acompanhar progressão de casos de LV. ${ }^{225}$

Na tentativa de compreender o processo de urbanização da LV realizou-se uma análise histórica da doença, desde a sua primeira descrição em 1936 até o surgimento das epidemias nas grandes brasileiras, no decorrer das ultimas três décadas.

O entendimento acerca do intenso processo migratório da população brasileira no período do estudo foi utilizado para compreender a consolidação da LV urbana. Neste contexto, as medidas de controle recomendadas pelo MS, por serem centradas exclusivamente na dinâmica de transmissão da doença, não atendem ao efetivo controle, tornando-se um desafio para as políticas publicas de saúde. 


\section{PERSPECTIVAS}

A partir dos estudos desenvolvidos nesta tese, buscou-se demonstrar a importância da LV como problema de saúde pública no Brasil. Além disto, foram considerados aspectos relacionados às estratégias de controle tradicionalmente implementadas no país, as quais se apresentam, atualmente, insuficientes a ponto de alcançar a magnitude da doença. Tal situação denota dificuldades enfrentadas no controle, permitindo a manutenção do ciclo de transmissão da LV nos centros urbanos do Brasil.

Diante do exposto, sugere-se que esta temática seja analisada no delineamento de novos estudos a fim de avaliar a eficácia e a efetividade dessas medidas a serem consideradas nas políticas de controle da LV. 


\section{REFERÊNCIAS}

1. Mauricio IL, Stothard JR, Miles MA. The strange case of Leishmania chagasi. Parasitol. today. 2000;16:188-189.

2. Lukes J, Mauricio IL, Schönian G, Dujardin JC, Soteriadou K, Dedet JP et al. Evolutionary and geographical history of the Leishmania donovani complex with a revision of current taxonomy. Proc. Natl. Acad. Sci. USA. 2007;104(22):9375-80.

3. Belo VS, Werneck GL, Barbosa DS, Simoes TC, Nascimento BW et al. Factors associated with visceral Leishmaniasis in the Americas: a systematic review and metaanalysis. PLoS. Negl. Trop. Dis. 2013;7:e2182.

4. Lainson R, Rangel EF. Lutzomyia longipalpis and the eco-epidemiology of american visceral Leishmaniasis, with particular reference to Brazil - A Review. Mem. Inst. Oswaldo Cruz. 2005;100:811-827.

5. Maia-Elkhoury ANS, Alves WA, Sousa-Gomes ML, Sena JM, Luna EA. Visceral Leishmaniasis in Brazil: trends and challenges. Cad. saúde pública. 2008;24:2941-7.

6. Organization WH. Investing to overcome the global impact of neglected tropical diseases: third WHO report on neglected diseases. Geneva: WHO Press. 2015.

7. Marcondes M, Rossi CN. Leishmaniose Visceral no Brasil. Braz. J. Vet. Res. Anim. Sci. 2013;50(5):341-352.

8. Chappuis F, Sundar S, Hailu A, Ghalib H, Rijal S, Peeling RW, Alvar J, Boelaert M. Visceral Leishmaniasis: what are the needs for diagnosis, treatment and control?. Nat Rev Microbiol. 2007;5:873-882.

9. Palatnik-de-Sousa CB, Santos WR, França-Silva JC, Costa RT, Reis AB, Palatnik M, Mayrink W, Genaro O. Impact of canine control on the epidemiology of canine and human visceral Leishmaniasis in Brazil. Am. J. Trop. Med. Hyg. 2001;65(5):510-517.

10. Werneck GL, Farias TJC, Farias GC, Silva FO, Chaves FC, Gouvêa MV, Costa CHN, Carvalho FA. Avaliação da efetividade das estratégias de controle da leishmaniose visceral na cidade de Teresina, Estado do Piaú, Brasil: resultados do inquérito inicial 2004. Epidemiol. serv. Saúde. 2008;17:87-96.

11. Alvar J, Yactayo S, Bern C. Leishmaniasis and poverty. Trends Parasitol. 2006;22:5527.

12. Vieira JBF, Coelho CE. Leishmaniose visceral ou calazar: Aspectos epidemiológicos e de controle. Rev. Soc. Bras. Med. Trop. 1998;31:85-92.

13. Brasil. Ministério da Saúde. Manual de Vigilância e Controle da Leishmaniose visceral. Brasília: Ministério da Saúde. 2014. 
14. Maciel BL, Valverde JG, Rodrigues-Neto JF, Freire-Neto F, Keesen TS et al. Dual immune modulatory effect of vitamin A in human visceral Leishmaniasis. PLoS One. 2014;9:e107564.

15. PAHO. Pan American Health Organization. Cutaneous and Mucosal Leishmaniasis [Internet]; 2014. Disponível em http://www.paho.org/hq/index.php?option=com_content $\&$ view=article7id=6417\&Itmd= 39345\&lang+en. Acesso em: 10 de abril de 2015.

16. Penna H. Leishmaniose visceral no Brasil. Bras Med. 1934;18:940-50.

17. Pondé R, Mangabeira O, Jansen G. Alguns dados sobre a Leishmaniose visceral americana e a doença de Chagas no Nordeste Brasileiro (Relatório de uma excursão realizada nos estados do Ceará, Pernambuco e Bahia). Mem Inst Oswaldo Cruz. 1942;37:333-352.

18. Deane LM, Deane MP. Leishmaniose visceral urbana (no cão e no homem) em Sobral, Ceará. Hospital, Rio de Janeiro. 1955;47:75-87.

19. Bevilacqua PD et al. Urbanização da leishmaniose visceral em Belo Horizonte. Arq. Bras. Med. Vet. Zootec. 2001;53(1):1-8.

20. Costa $\mathrm{CH}$. Characterization and speculations on the urbanization of visceral Leishmaniasis in Brazil. Cad. Saude Publica. 2008;24(12):2959-63.

21. Costa CH, Pereira HF, Araújo MV. Visceral Leishmaniasis epidemic in the State of Piauí, Brazil, 1980-1986. Rev Saude Publica. 1990;24(5):361-72.

22. Werneck GL. Visceral Leishmaniasis in Brazil: rationale and concern related to reservoir control. Rev Saude Publica. 2014;48(5):851-6.

23. Harvay MO, Olliaro PL, Costa DL, Costa CH. Urban parasitology: visceral Leishmaniasis in Brazil. Trends Parasitol. 2011;27(9):403-9.

24. Brito F. O deslocamento da população brasileira para as metrópoles. Estudos Avançados. 2006;20(57):221-36.

25. WHO. The World Health Organization. Available at: http://www.who.int/wer. Acesso em: $15 / 02 / 2015$.

26. Druzian AF, de Souza AS, de Campos DN, Croda J, Higa MG Jr, Dorval ME et al. Risk Factors for Death from Visceral Leishmaniasis in an Urban Area of Brazil. PLoS Negl Trop Dis. 2015;9(8):e0003982.

27. Góes MAO, Jeraldo VLS. Características clínicas e epidemiológicas dos pacientes internados com leishmaniose visceral em hospital de referência. Rev Bras Clin Med. 2013;11(3):227-31. 
28. Guerreiro J, Ribeiro S, Carvalho EM, Badaró R, Rocha H. Infecção bacteriana em pacientes portadores de Leishmaniose Visceral. Mem. Inst. Oswaldo Cruz. 1985;80(4): 447-45.

29. Herwalt BL. Leishmaniasis. The Lancet. 1999; 354.

30. Faria AR, Andrade HM. Diagnóstico de Leishmaniose Visceral Canina: grandes avanços tecnológicos e baixa aplicação prática. Ver Pan-Amaz Saude. 2012;3(2):47-57.

31. Assis TSM, Braga ASC, Pedras MJ, Barral AMP, Siqueira IC, Costa CHN et al. Validação do teste imunocromatográfico rápido IT-LEISH® para o diagnóstico da leishmaniose visceral humana. Epidemiol. Serv. Saúde. 2008;17(2):107-16.

32. Caldas AJM, Aquino DMC, Ferreira NV, Silva MAPS, Silva EL, Costa ASA, Barral AP. Avaliação imunológica da intradermoreação de Montenegro. Rev. pesq. Saúde. 2010;11(2):9-13.

33. Stockdale L, Newton R. A review of preventative methods against human Leishmaniasis infection. PLoS Negl Trop Dis. 2013;7(6):e2278.

34. Brasil. Ministério da Saúde. Manual de Vigilância e Controle da Leishmaniose visceral. Brasília: Ministério da Saúde. 2006.

35. Freitas-Junior LH, Chatelain E, Kim HA, Siqueira-Neto JL. Visceral Leishmaniasis treatment: What do we have, what do we need and how to deliver it? Int J Parasitol. 2012;2:11-19.

36. Santarem AAA, Greggianin GF, Debastiani RG, Ribeiro JBP, Polli DA, Sampaio RNR. Effectiveness of miltefosine-pentoxifylline compared to miltefosine in the treatment of cutaneous Leishmaniasis in C57B1/6 mice. Rev Soc Bras Med Trop. 2014;47(4):517-20.

37. Prado, PF et al. Epidemiological aspects of human and canine visceral Leishmaniasis in Montes Claros, State of Minas Gerais, Brazil, between 2007 and 2009. Rev. Soc. Bras. Med. Trop. 2011;44(5):561-566.

38. Romero, GAS.; Boelaert, M. Control of visceral Leishmaniasis in Latin America - A Systematic Review. PLoS Negl Trop Dis. 2010;4(1):e584.

39. Brasil. Ministério da Saúde. Manual de Vigilância e Controle da Leishmaniose visceral. Brasília: Ministério da Saúde. 2010.

40. Werneck GL, Hasselmann MH, Gouvêa TG. Panorama dos estudos sobre nutrição e doenças negligenciadas no Brasil. Ciênc. saúde coletiva. 2011;16(1):39-62.

41. Desjeux P. Leishmaniasis: current situation and new perspectives. Comp Immunol Microbiol Infect Dis. 2004;27:305-18.

42. Lainson R, Shaw JJ. New World Leishmaniasis. In: Cox F.E.G., Wakelin D., Gillespie S.H., Despommier D.D., editors. Topley \& Wilson's Microbiology \& Microbial Infections. tenth ed. Parasitology, Hodder Arnold, London: 2006: 313-349. 
43. Bates PA. Transmission of Leishmania metacyclic promastigotes by phlebotomine sand flies. Int J Parasitol. 2007;37(10):1097-106.

44. Freitas VC. O processo de interação de Leishmania (Leishmania) chagasi com (Lutzomyia) longipalpis e a importância do lipofosfoglicano (LPG). 210f. Belo Horizonte, 2010. Tese (Doutorado em Ciências pelo Programa de Pesquisas René Rachou)-Fundação Oswaldo Cruz-Ministério da Saúde.

45. Ready PD. Epidemiology of visceral Leishmaniasis. Clinical Epidemiology. 2014;6:14754.

46. Pavli A, Maltezou, HC. Lishmaniasis, and emerging infecton in travelers. Int J Infect Dis. 2010;14(12):e1032-e1039.

47. Silveira FT, Corbett CEP. Leishmania chagasi Cunha \& Chagas, 1937: indigenous or introduced? A brief review. Rev Pan-Amaz Saúde. 2010;1:143-7.

48. Lainson R, Shaw JJ. Evolution, classification and geographical distribution. In: Peteers W, Killick-Kendrick R, editors. The Leishmaniasis in Biology and Medicine. London. Press Inc. 1987:12-120.

49. Chagas E, Cunha A, Castro G, Ferreira L, Romana C. Leishmaniose visceral americana: relatório dos trabalhos da comissão encarregada dos estudos da leishmaniose visceral americana em 1936. Mem Inst Oswaldo Cruz. 1937;32(3):321-85.

50. Killick-Kendrick R. Some epidemiological consequences of the evolutionary fit between Leishmania and their phlebotomine vectors. Bull Soc Pathol Exotic Filiales 1985;78:747-55.

51. Dantas-Torres F, Brandão-Filho SP. Visceral Leishmaniasis in Brazil: revisiting paradigms of Epidemiology and control. Rev Inst Med Trop. 2006;48(3):151-6.

52. Lainson R, Dye C, Shaw JJ, MacDonald DW, Courtenay O, Souza AAA, et al. Amazonian visceral Leishmaniasis - distribution of the vector Lutzomyia longipalpis (Lutz \& Neiva) in relation to the fox Cerdocyon thous (Linn.) and the efficiency of this reservoir host as a source of infection. Mem Inst Oswaldo Cruz. 1990 janmar;85(1):135-7.

53. Jackson PR, Stiteler JM, Wohlhieter JA, Reed SG, Badaró R, Inverso JA, Jackson JE. Characterization of Leishmania responsible for visceral disease in Brazil by restriction endonuclease digestion and hybridization of kinetoplast DNA. In Proc 11th Internat Congr Trop Med Malar Calgary, Canada. 1984:68.

54. Gramiccia M, Smith DF, Angelici MC, Ready PD, Gradoni L. A kinetoplast DNA probe diagnostic for Leishmania infantum. Parasitology. 1992;105:29-34.

55. Rangel EF, Lainson R. Importância Médico-Veterinária. In: Rangel EF, Lainson R, organizadores. Flebotomíneos do Brasil. Riop de Janeiro; Ed. FIOCRUZ. 2003:15-9. 
56. Jackson PR, Wohlhieter J, Hockmeyer WT. Leishmania characterization by restriction endonuclease digestion of kinotoplastic DNA. In Abstr Vth Internat Congr Parasitol Toronto, Canada. 1982:342.

57. Prata, A; Silva, LA. Calazar. In: Coura, JR. Dinâmica das Doenças Infecciosas e Parasitárias, Rio de Janeiro. Guanabara Koogan. 2005;1:713-732.

58. Dostalova A, Volf P. Leishmania development in sand flies: parasite-vector interactions overview. Parasit Vectors. 2012;5:276.

59. Davies CR, Kaye P, Croft SL, Sundar S. Leishmaniasis: new approaches to disease control. BMJ. 2003;326:377-82.

60. Murray HW, Berman JD, Davies CR, Saravia NG. Advances in Leishmaniasis. Lancet. 2005;366:1561-77.

61. Silva EA, Andreotti R, Honer MR. Comportamento de Lutzomyia longipalpis, vetor principal da leishmaniose visceral americana, em Campo Grande, Estado do Mato Grosso do Sul. Rev Soc Bras Med Trop. 2007;40(4):420-5.

62. Bray DP, Alves GB, Dorval ME, Brazil RP, Hamilton JG. Synthetic sex pheromone attracts the Leishmaniasis vector Lutzomyia longipalpis to experimental chicken sheds treated with insecticide. Parasit Vectors. 2010;3:16.

63. Pessoa SB, Barreto MP. Leishmaniose Tegumentar Americana. Rio de Janeiro: Imprensa Nacional/São Paulo: Serviço de Parasitologia, Departamento de Medicina, Faculdade de São Paulo. 1948.

64. Almeida PS, Andrade AJ, Sciamarelli A, et al. Geographic distribuition of phlebotomine sandfly species (Diptera: Psychodidae) in Central-West Brazil. Mem Inst. Oswaldo Cruz. 2015;110(4):551-9.

65. Ladeia-Andrade S, Fe NF, Sanguinette CC, Andrade Filho JD. Description of Trichophoromyia uniniensis, a new phlebotomine species (Diptera: Psychodidae: Phlebotominae) of Amazonas state, Brazil. Parasit Vectors. 2014;7:400.

66. Hamilton JGC, Maingon R, Alexander B, Ward R, Brazil RP. Analysis of the sex pheromone extract of individual male Lutzomyia longipalpis sandflies from six region in Brazil. Med Vet Entomol. 2005;19:480-8.

67. Sacks DL, Lawyer P, Kamhawi S. The Biology of Leishmania - sand fly interactions. In: Myler P, Fasel N, editores. Leishmania: After the Genome. UK: Caister Academic Press Norfolk. 2008:205-38.

68. Picado A, Dash AP, Bhattacharya S, Boelaert M. Vector control interventions for visceral Leishmaniasis elimination initiative in South Asia, 2005-2010. Indian J Med Res. 2012;136(1):22-31.

69. Costa PL. Comportamento da Fauna de Flebotomíneos com ênfase em Lutzomyia longipalpis, em Área endêmica para Leishmaniose Visceral no Município de Passira, 
Agreste Pernambucano. 92f. Dissertação (Pós-Graduação em Saúde Pública do Centro de Pesquias Aggeu Magalhães. Fundação Oswaldo Cruz. Recife. 2011

70. Hamilton JGC. Sandfly pheromones - their biology and potential for use in control programmes. Parasite. 2008;15:252-256.

71. Lutz Adolpho, Neiva Arthur. Contribuição para o conhecimento das especies do genero Phlebotomus existentes no Brazil. Mem. Inst. Oswaldo Cruz. 1912;4(1): 84-95.

72. Soares RPPS, Turco SJ. Lutzomyia longipalpis (Diptera: Psychodidae: Phlebotominae): a review. An Acad Bras Cienc. 2003;75(3):301-30.

73. Dantas-Torres Filipe, Andrade Andrey José de, Tenório Klaudia Emanuela Ramos, Andrade Filho José Dilermando, Balbino Valdir de Queiroz, Brandão-Filho Sinval Pinto. Phlebotomine sand flies (Diptera: Psychodidae: Phlebotominae) in the State of Pernambuco. Rev. Soc. Bras. Med. Trop. 2010;43(6):733-736.

74. Galati EAB. Morfologia e taxonomia: classificação de Phlebotominae. In: RANGEL, E. F.; LAINSON, R. (Org.). Flebotomíneos do Brasil. Editora Fiocruz, Rio de Janeiro. 2003;2:23-52.

75. Lemos JC, Lima SC, Neto AAP, Casagrande B, Vieira GSS, Ferrete JA, et al. Encontro de Lutzomyia longipalpis na área de implantação da usina hidrelétrica Capim Branco I, na bacia do rio Araguari, no município de Uberlândia, Minas Gerais - Brasil. Revista Caminhos de Geografia. 2004;12:186-198.

76. Missawa NA, Veloso MAE, Lima GBM, Michalsky EM, Dias ES. Evidência de transmissão de leishmaniose visceral por Lutzomyia cruzi no município de Jaciara, estado de Mato Grosso, Brasil. Rev Soc Bras Med Trop. 2011;44:76-78.

77. Pita-Pereira D, Cardoso MAB, Alves CR, Brazil RP, Britto C. Detection of natural infection in Lutzomyia cruzi and Lutzomyia forattinni (Diptera: Psycodidae: Phlebotominae) by Leishmania infantum chagasi in an endemic área of visceral Leishmaniasis in Brazil using a PCR multiplex assay. Acta Trop. 2008;107:66-9.

78. Costa JML. Epidemiologia das leishmanioses no Brasil. Gazeta Médica da Bahia. 2005;75:3-17.

79. Missawa NA, Lima GBM. Distribuição espacial de Lutzomyia longipalpis (Lutz \& Neiva, 1912) e Lutzomyia cruzi (Mangabeira, 1938) no Estado de Mato Grosso. Ver Soc Bras Med Trop. 2006;39:337-340.

80. Galati EAB, Nunes VLB, Rego Jr FA, Oshiro ET, Chang MR. Estudo de flebotomíneos (Diptera: Psychodidae) em foco de leishmaniose visceral no estado de Mato Grosso do Sul, Brasil. Rev Saúde Pública. 1997;31:378-390.

81. Santos SO, Arias J, Ribeiro AA, Hoffmann MP, Freitas TA, Malacco MAF. Incrimination of Lutzomyia cruzi as a vector of American visceral Leishmaniasis. Med. Vet. Entomol. 1998;12:315-317. 
82. Marcondes CB, Conceição MBF, Portes MGT, Simão BP. Phlebotomine sandflies in a focus of dermal Leishmaniasis in the eastern region of the Brazilian State of Santa Catarina preliminary results (Diptera: Psychodidae). Revista da Sociedade Brasileira de Medicina Tropical. 2005;38:353-355.

83. Galati EAB, Nunes VLB, Boggiani PC, Dorval MEC, Cristaldo G, Rocha HC, et al. Phlebotomines (Diptera: Psychodidae) in forested areas of the Serra da Bodoquena, state of Mato Grosso do Sul, Brazil. Mem Inst Oswaldo Cruz. 2006;101:175-193.

84. Rebêlo JMM, Oliveira-Pereira YN. Flebotomíneos (Diptera, Psychodidae) de matas de terra firme e de várzea, do município de Paragominas, Estado do Pará, Brasil. Acta Amaz. 2001;31:145-54.

85. Missawa NA, Maciel GBML, Rodrigues H. Distribuição geográfica de Lutzomyia (Nyssomyia) whitmani (Antunes \& Coutinho, 1939) no Estado de Mato Grosso. Revista da Sociedade Brasileira de Medicina Tropical. 2008;41(4):369-373.

86. Ribas LM, Zaher VL, Shimozako HJ, Massad E. Estimating the optimal control of Zoonotic visceral Leishmaniasis by the use of a mathematic model, London. The Scientific World Journal. 2013;2013. Article ID 810380.

87. Souza NP, Almeida AB, Freitas TP, Paz RC, Dutra V, Nakazato L et al. Leishmania (Leishmania) infantum chagasi in wild canids kept in captivity in the State of Mato Grosso. Revta Soc. Bras. Med. Trop. 2010;43:333-335.

88. Deane L, Deane M. Encontro de Leishmanias nas vísceras e na pele de uma raposa, em zona endêmica de calazar, nos arredores de Sobral, Ceará. O Hospital. 1954;45(4):45-7

89. Sherlock IA, Miranda JC, Sadigursky M, Grimaldi Jr G. Natural infection of the opossum Didelphis albiventris (Marsupialia Didelphidae) with Leishmania donovani in Brazil. Mem Inst Oswaldo Cruz. 1984;79:511.

90. de Melo EC, Fortaleza CMCB. Challenges in the terapy of Visceral Leishmaniasis in Brazil: a public health perspective. Journal of Tropical Medicine 2013;2013. Article ID 319234. Disponível em: <http://www.hindawi.com/journals/jtm/2013/319234/>. Acesso em 10/02/2014.

91. Góes MAO, Melo CM, Jeraldo VLS. Série temporal da leishmaniose visceral em Aracaju, estado de Sergipe, Brasil (1999 a 2008). Rev Bras Epidemiol. 2012;15:298-30.

92. Garcez LM, Cardoso JF, Chagas AP, Miranda JFC, de Souza GCR, Soares DC et al. Vigilância da leishmaniose visceral em localidades epidemiologicamente distintas em Juruti, um município minerário do Estado do Pará, Brasil. Rev Pan-Amaz Saúde. 2010;1(1): 107-116.

93. Afonso MMS, Duarte R, Miranda JC, Caranha L, Rangel EF. Studies on the feeding habits of Lutzomyia (Lutzomyia) longipalpis (Lutz\&Neiva, 1912) (Diptera: Psychodidae: Phlebotominae) populations from endemic areas of american visceral Leishmaniasis in northeastern Brazil. Journal of Tropical Medice 2012;2012(2012):1-5. 
94. Solano-Gallego L, Rogríguez-Cortés A, Iniesta L, Pastintana J, Quintana J; Pastor, J; Espada Y; Portús M; Alberola, J. Cross-sectional serosurvey of feline Leishmaniasis in ecoregions around the Northwestern Mediterranean. Am J Trop Med Hyg. 2007;76(4):676-80.

95. Vita S; Santori D, Aguzzi I, Petrotta E, Luciani A. Feline Leishmaniasis and ehrlichisis: serological investigation in Abruzzo region. Vet Res Comm. 2005;29(2):319-321.

96. Maia, C.; Campino, L. Can domestic cats be considered reservoir hosts of zoonotic Leishmaniasis? Trends Parasitol. 2011;27(8):341-344.

97. Savani ESM, de Oliveira Camargo MC, de Carvalho MR, Zampieri RA, dos Santos MG, D'auria SR, et al. The first record in the Americas of an autochthonous case of Leishmania (Leishmania) infantum chagasi in a domestic cat (Felix catus) from Cotia County, São Paulo State, Brazil. Veterinary Parasitology. 2004;120(3):229-233.

98. Vides JP, Schwardt TF, Sobrinho LSV, Marinho M, Laurentu MD, Biondo AW, et al. Leishmania chagasi infection in cats with dermatologic lesions from an endemic area of visceral leishmaniosis in Brazil. Veterinary Parasitology. 2011;178:22-28.

99. Sobrinho LSV, Rossi CN, Vides JP, Braga ET, Gomes AD, LIMA VMF, et al. Coinfection of Leishmania chagasi with Toxoplasma gondii, Feline Immunodeficiency Virus (FIV) and Feline Leukemia Virus (FeLV) in cats from an endemic area of zoonotic visceral Leishmaniasis. Veterinary Parasitology. 2012;187:302-306.

100. Sobrinho LSV, Rossi CN, Laurenti MD, Lima, VMF, Costa TAC, Vides J.P, et al. Absence of Association Between Leishmania sp, FIV and FeLV Infections, in Cats From an Endemic Area for Visceral Leishmaniasis in Brazil (resumo online). In Proceedings of ACVIM Forum \& Canadian Veterinary Medical Association Convention, Montreal, Canada. 2010. Disponível em: < http://www.vin.com/Members/Proceedings/Proceedings.plx?CID=acvim2010\&PID=pr5 5567\&O=VIN> Acesso em: 30/10/2013.

101. Cardoso L, Mendão C, Carvalho LM, Prevalence of Dirofilaria immitis, Ehrlichia canis, Borrelia burgdorferi sensu lato, Anaplasma spp. And Leishmania infantum in apparently healthy and CVBD-suspect dogs in Portugal - a national serological study. Parasites \& Vectors. 2012;5:62.

102. Maroli M, Pennisi MG, Muccio TD, Khoury C, Gradoni L, Gramiccia M. Infection of sand flies by a cat naturally infected with Leishmania infantum. Vet Parasitol. 2007;145:357-360.

103. Silva SM, Rabelo PFB, Gontijo NF, Ribeiro RR, Melo MN, Ribeiro VM, et al. First report of infection of Lutzomyia longipalpis by Leishmania (Leishmania) infantum from a naturally infected cat of Brazil. Vet Parasitol. 2010;174:150-154.

104. Alexander B, de Carvalho RL, Mccallum H, Pereira MH. Role of the domestic chicken (Gallus gallus) in the epidemiology of urban visceral Leishmaniasis in Brazil. Emerg Infect Dis. 2002;8(12):1480-1485. 
105. Figueiró-Filho EA, Duarte G, El-Beitune P, Quintana SM, Maia TL. Visceral Leishmaniasis (kala-azar) and pregnancy. Infect Dis Obstet Gynecol. 2004;12(1):31-40.

106. Lages RC, de Castro JAF, do Monte SJH, Neto JTM, de Andrade HM. Leishmaniose Visceral e Transplante Renal: Relato de Caso, Estudo Prospectivo de Doadores e Receptores e Proposta de Diagnóstico Precoce da Infecção em Área Endêmica. J Bras Nefrol. 2004;26(1):51-56.

107. Low GC, Cooke WE. A congenital case of kala-azar. Lancet. 1926;208(5389):1209-11.

108. Gradoni L, Gaeta GB, Pellizzer G, Maisto A, Scalone A. Mediterranean visceral Leishmaniasis in pregnancy. Scand J Infect Dis. 1994;24(5):627-9.

109. Caldas AJM, Costa JM, Gama ME, Ramos EA, Barral A. Visceral leihmaniasis in pregnancy: a case report. Acta Trop. 2003;88(1):39-43.

110. Meinecke CK, Schottelius J, Oskam L, Fleischer B. Congenital transmission of visceral Leishmaniasis (kala-azar) from an asymptomatic mother to her child. Pediatrics. 1999;104(5):65.

111. Eltoum IA, Zijlstra EE, Ali MS, Ghalib HW, Satti MM, Eltoum B, et al. Congenital kala-azar and Leishmaniasis in the placentas. Am J Trop Med Hyg. 1992;46(1):57-62.

112. Pagliano P, Carannante N, Rossi M, Gramiccia M, Gradoni L, Faella FS, et al. Visceral Leishmaniasis in pregnancy: a case series and a systematic review of the literature. $\mathrm{J}$ Antimicrob Chemother. 2005;55(2):229-33.

113. Ferreira MGPA, Fattori KR, Souza F, Lima VMF. Potential role for dog fleas in the cycle of Leishmania spp. Vet Parasitol. 2009;165:150-154.

114. Coutinho MT, Linardi PM. Can fleas from dogs infected with canine visceral Leishmaniasis transfer the infection to other mammals? Vet Parasitol Amsterdam. 2007 Jul;47(3/4):320-5.

115. Guerin PJ, Olliaro P, Sundar S, Boelaert M, Croft SL, Desjeux P, et al. Visceral Leishmaniasis: current status of control, diagnosis, and treatment, and a proposed research and development agenda. Infectious Disease. 2002;2.

116. Alvar J, Vélez ID, Bern C, Herrero M, Desjeux $\mathrm{P}$, Cano J, et al. Leishmaniasis worldwide and global estimates of its incidence. PLoS One. 2012;7:e35671.

117. Ortiz RC, Anversa L. Epidemiology of visceral Leishmaniasis in Bauru, São Paulo, Brazil, 2004-2012: a descriptive study. Epidemiol. Serv. Saúde. 2015 jan-mar;24(1):97104.

118. Góes MAO, Jeraldo VLS, Oliveira AS. Urbanização da leishmaniose visceral: aspectos clínicos e epidemiológicos em Aracaju, Sergipe, Brasil. Rev Bras Med Fam Comunidade. 2014;9(31):119-26. 
119. Cavalcante IJM, Vale MR. Aspectos epidemiológicos da leishmaniose visceral (calazar) no Ceará no período de 2007 a 2011. Rev Bras Epidemiol. 2014;17(4): 911-924.

120. Almeida ABPF, Mendonça AJ, Sousa VRF. Prevalência e epidemiologia da leishmaniose visceral em cães e humanos, na cidade de Cuiabá, Mato Grosso, Brasil. Cienc Rural. 2010;40(7): 1610-1615.

121. Babuadze, G. Alvar J, Argaw D, de Koning HP, Iosava M, Kekelidze M, et al. Epidemiology of visceral Leishmaniasis in Georgia. PLoS Negl Trop Dis. 2014 Mar;8(3):e2725-35.

122. Oliveira AKM, Resende UM, Schleder EJD. Espécies vegetais e suas síndromes de dispersão em um remanescente de cerrado (sentido restrito) do município de Campo Grande, Mato Grosso do Sul. Ambiência Guarapuava (PR). 2014;10(2):565-580.

123. Botelho ACA, Natal D. Primeira descrição epidemiológica da leishmaniose visceral em Campo Grande, Estado de Mato Grosso do Sul. Rev Soc Bras Med Trop. 2009;42:503508 .

124. Mock BA, Nacy CA. Hormonal modulation of sex differences in resistance to Leishmania major systemic infections. Infect Immun. 1988 Dec;56(12):3316-9.

125. Pung OJ, Tucker AN, Vore SJ, Luster MI. Influence of estrogen on host resistance: increased susceptibility of mice to Listeria monocytogenes correlates with depressed production of interleukin 2. Infect Immun. 1985 Oct;50(1):91-6.

126. Caldas AJM. Costa JM, Silva AA, Vinhas V, Barral A. Risk factors associated with asymptomatic infection by Leishmania chagasi in north-east Brazil. Trans R Soc Trop Med Hyg. 2002 Jan-Feb;96(1):21-8.

127. Oliveira AL, Paniago AMM, Dorval MEC, Oshiro ET, Leal CR, Sanches M, et al. Emergent outbreak of visceral Leishmaniasis in Mato Grosso do Sul State. Rev Soc Bras Med Trop. 2006 Sep-Oct:39(5):446-50.

128. Pedrosa CM, da Rocha EM. Clinical and epidemiological aspects of visceral Leishmaniasis in children up to 15 years of age in Alagoas, Brasil. Rev Soc Bras Med Trop. 2004 Jul-Aug;37(4): 300-4. 2004.

129. Desterro M do, Costa SB, Blanca Inez JM, Alvim P, Nakatani OCB, Reed M, et al. Aspectos epidemiológicos determinantes na manutenção da leishmaniose visceral no Estado do Maranhão-Brasil. Rev Soc Bras Med Trop. 1996;29(3):233-240.

130. Queiroz MJ, Alves JG, Correia JB. Leishmaniose visceral: características clínicoepidemiológicas em crianças de área endêmica. J Pediatr. 2004;80(2):141-6.

131. Xavier-Gomes LM, Costa WB, Prado PFD, Oliveira-Campos M, Leite MTDS. Clinical and epidemiological characteristics of visceral Leishmaniasis in children hospitalized at a reference university hospital in the north of Minas Gerais, Brazil. Rev Bras Epidemiol. 2009;12(4):549-555. 
132. Brustoloni YM. Leishmaniose Visceral em crianças no Estado do Mato Grosso do Sul, Brasil: contribuição ao diagnóstico e ao tratamento. 144F. Campo Grande, 2006. Tese ( Doutorado em Ciências da Saúde pelo Programa Multiinstitucional em Ciências da Saúde.

133. Jain K, Jain NK. Novel therapeutic strategies for treatment of visceral Leishmaniasis. Drug Discov Today, 2013;18(23):1272-1281.

134. Martins-Melo FR, Lima MdS, Ramos AN Jr., Alencar CH, Heukelbach J. Mortality and Case Fatality Due to Visceral Leishmaniasis in Brazil: A Nationwide Analysis of Epidemiology, Trends and Spatial Patterns. PLoS ONE. 2014;9:e93770.

135. Sousa-Gomes ML de, Maia-Elkhoury ANS, Pelissari DML, Junior FEF, Martins de JSM, Cechinel MP. Coinfecção Leishmania-HIV no Brasil: aspectos epidemiológicos, clínicos e laboratoriais. Epidemiol. Serv. Saúde. 2011 Dez;20(4):519-526

136. Alvar J, Aparicio P, Aseffa A, Boer MD, Cañavate C, Dedet JP, et. al. The Relationship between Leishmaniasis and AIDS: the Second 10 Years. Clin. Microbiol. Rev. 2008;21(2):334-359.

137. Marques N, Cabral S, Sá R, Coelho F, Oliveira J, Saraiva da Cunha JG, et al. Visceral Leishmaniasis and HIV infection in the HAART era. Acta Med Port. 2007;20:291-298.

138. Alves WA, Bevilacqua PD. Reflexões sobre a qualidade do diagnóstico da leishmaniose visceral canina em inquéritos epidemiológicos: o caso da epidemia de Belo Horizonte, Minas Gerais, Brasil, 1993-1997. Cad. Saúde Pública. 2004 Jan-Fev;20(1):259-265.

139. Malafaia G. Co-infecção/Leishmania: um sério problema de saúde pública. Ouro Preto, Brasil. Rev Saúde Pública. 2009;43(1):195.

140. Oddone CR. Leishmaniosis visceral: a 101 años del primer caso diagnosticado en las Américas. Mem. Inst. Investig. Cienc. Salud. 2012 Jun;10(1):100-104.

141. Gould IT, Perner MS, Santini MS, Saavedra SB, Bezzi G, Maglianese MI, et al. Visceral Leishmaniasis in Argentina. Cases notification and distribution of vectors (2006-2012). Medicina (B Aires). 2013;73:104-110.

142. Barrio A, Parodi CM, Locatelli F, Mora MC, Basombrío MA, Korenaga M, et al. Leishmania infantum and human visceral Leishmaniasis, Argentina. Emerg Infect Dis. 2012;18:354-355.

143. Organização Pan-Americana da Saúde. Informe Leishmanioses $\mathrm{N}^{\mathrm{o}} 2$ - Junho de 2014. Disponível em: http://new.paho.org/Leishmaniasis. Acesso em: 30/11/2014

144. Deane LM, Deane MP. Visceral Leishmaniasis in Brazil: geographical distribution and transmission. Revista do Instituto de Medicina Tropical de São Paulo. 1962;4(3):198212.

145. Veronesi R, Jamra M, Silva O, Cruz O, Fiorilo A. Leishmaniose visceral (kala-azar): Estudo do quadro clínico, hematológico e eletroforético. Rev Hosp Clin. 1954;9(1). 
146. Lacerda MM. The Brazilian Leishmaniasis control program. Mem Inst Oswaldo Cruz. 1994;89:489-495.

147. Drumond KO, Costa FA. Forty years of visceral Leishmaniasis in the State of Piaui: a review. Rev Inst Med Trop. 2011;53(1):3-11.

148. Mendonca FA; Souza AV, Dutra DA. Saúde pública, urbanização e dengue no Brasil. Soc. Nat. 2009;21(3):257-269.

149. Souza NA, Andrade-Coelho CA, Vigoder FM, Ward RD, Peixoto AA. Reproductive isolation between sympatric and allopatric Brazilian populations of Lutzomyia longipalpis s.1. (Diptera: Psy-chodidae). Mem Inst Oswaldo Cruz. 2008;103:216-219.

150. Monteiro EM, França-Silva JC, Costa RT, Costa DC, Barata RA, Paula EV, et al. Leishmaniose visceral: estudo de flebotomíneos e infecção canina em Montes Claros, Minas Gerais. Rev Soc Bras Med Trop. 2005;38:147-152.

151. Victora CG, Barreto ML, Leal MC, Monteiro CA, Schmidt MI, Pain J, et al. Condições de saúde e inovações nas políticas de saúde no Brasil: o caminho a percorrer. Lancet. 2011;6:90-102.

152. Gontijo CMF, Melo MN. Leishmaniose visceral no Brasil: quadro atual, desafios e perspectivas. Rev Epidemiol. 2004;7:338-49.

153. Dantas-Torres F. Canine Leishmaniasis in South America. Paras Vectors. 2009; 2(1):18.

154. Baneth G, Koutinas AF, Solano-Gallego L, Bourdeau P, Ferrer L. Canine leishmaniosis - new concepts and insights on an expanding zoonosis: part one. Trends Parasitol. 2008;24(7):324-330.

155. Laurenti MD, Rossi CN, Matta MLR, Tomokane TY, Corbett CEP, Secundino NFC, et al. Asymptomatic dogs are highly competent to transmit Leishmania (Leishmania) infantum chagasi to the natural vector. Vet Parasitol 2013;196:296-300.

156. Alves WA. Leishmaniose visceral americana: situação atual no Brasil. Boletim Epidemiológico Paulista. 2009;6:25-29.

157. Carranza-Tamayo, CO, Carvalho MSL, Bredt A, Bofil MIR, Rodrigues RMB, Silva AD, Cortez SMFC, Romero GAS. Autochthonous visceral Leishmaniasis in Brasília, Federal District, Brazil. Rev Soc Bras Med Trop. 2010;43:396-399.

158. Oliveira CDL, Assunção RM, Reis IA, Proietti FA. Spatial distribution of human and canine visceral Leishmaniasis in Belo Horizonte, Minas Gerais State, Brasil, 1994-1997. Cad Saude Publica. 2001 Sep-Oct;17(5):1231-9.

159. Quaresma PF, Murta SM, Ferreira Ede C, Da Rocha-Lima AC, Xavier AA, Gontijo CM. Molecular diagnosis of canine visceral Leishmaniasis: identification of Leishmania 
species by PCR-RFLP and quantification of parasite DNA by real-time PCR. Acta Trop 2009;111(3):289-294.

160. Lopes EGP, Magalhães DF, Silva JA, Haddad JPA, Moreira EC. Distribuição temporal e espacial da leishmaniose visceral em humanos e cães em Belo Horizonte-MG, 1993 a 2007. Arq Bras Med Vet e Zootec. 2010;62(5):1062-1071.

161. Oliveira EM, Pimenta AM. Perfil epidemiológico das pessoas portadoras de Leishmaniose Visceral no município de Paracatu - MG no período de 2007 a 2010. Revista Mineira de Enfermagem. 2014 Abr.-Jun;18(2):365-370.

162. Gonçalves AS, Guimarães ELAM, Oliveira MA, Morais MHF, Araújo VEM, da SILVA $\mathrm{JA}$, et al. Leishmaniose visceral: um desafio às políticas de saúde brasileiras. Periódico Científico do Núcleo de Biociências Centro Universitário Metodista Izabela Hendrix. 2013;03(6).

163. Silva ES, Gontijo CMF, Pacheco RS, Fiuza VOP, Brazil RP. Visceral Leishmaniasis in the Metropolitan Region of Belo Horizonte, State of Minas Gerais, Brazil. Mem Inst Oswaldo Cruz. 2001;96(3):285-291.

164. Mourão MVA, Toledo Jr A, Gomes LI, Freire VV, Rabelo, A; Parasite load and risk factors for poor outcome among children with visceral Leishmaniasis. A cohort study in Belo Horizonte, Brazil, 2010-2011; Mem Inst Oswaldo Cruz. 2014109(2):147-153.

165. Luz ZMP, Pimenta DN, Cabral ALV, Fiúza VOP, Rabello A.. A urbanização das leishmanioses e a baixa resolutividade diagnóstica em municípios da Região Metropolitana de Belo Horizonte. Rev. Soc. Bras. Med. Trop. 2001;34:249-254.

166. Margonari C, Freitas CR, Ribeiro RC, Moura ACM, Timbó M, Gripp AH et al. Epidemiology of visceral Leishmaniasis through spatial analysis, in Belo Horizonte municipality, state of Minas Gerais, Brazil. Mem Inst Oswaldo Cruz 2006;101:31-38.

167. Araújo VE, Morais MH, Reis IA, Rabello A, Carneiro M. Early clinical manifestations associated with death from visceral Leishmaniasis. PLoS Negl Trop Dis. 2012;6(2):e1511.

168. Borges BKA. Fatores de risco para leishmaniose visceral em Belo Horizonte. Dissertação de Mestrado (Escola de Veterinária. Universidade Federal de Minas Gerais) Belo Horizonte. 2006. 104 p.

169. Deane LM. Leishmaniose visceral. Estudo sobre reservatórios e transmissores realizado no Estado do Ceará. Tese. Serviço Nacional de Endemia Sanitária, Rio de Janeiro, 1956.

170. Fiquene SF. Analogias parasitorias, novo tratamento de leishmaniose. Revista Maranhão Médico, 1964;2:9-18.

171. Brandão AAR. Leishmaniose visceral no Maranhão: relato de um caso. Revista da Sociedade de Parasitologia e Doenças Tropicais do Maranhão. 1974;1:95-99. 
172. Silva AR. Leishmaniose visceral americana. Evolução de uma endemia de 1982 a 1985. Jornada de Parasitologia e Medicina Tropical, São Luís, Resumos, 9. 1986.

173. Costa JML, Viana GMC, Saldanha ACR, Nascimento MDSB, Alvim AC, Burattini MN, Silva AR. Leishmaniose visceral no Estado do Maranhão. A evolução de uma epidemia. Cad Saúde Pública. 1995;11:321-324.

174. Alencar JE. Estudos sobre a epidemiologia de calazar no estado de Ceará, Brasil. Calazar canino versos calazar humano: aspectos profiláticos e históricos. Rev Soc Bras Med Trop. 1987;20:156-157.

175. Mendes WS, Trovão JR, Silva AAM. Dinâmica da ocupação do espaço na cidade de São Luís e a leishmaniose visceral. Cad Saúde Pública. 2000;16(3):871-873.

176. Rodrigues ACE. Características Epidemiológicas e Distribuição Espacial da Enzootia Canina de Leishmaniose Visceral na Cidade de Teresina - Piauí, no período de 2003 2006. 101f. 2008. Dissertação (Mestrado em Saúde Pública). Fundação Oswaldo Cruz, Teresina, 2008.

177. Mestre GLC, Fontes CJF. A expansão da epidemia de leishmaniose visceral no Estado de Mato Grosso, 1998-2005. Rev Soc Bras Med Trop. 2007;40(1):42-48.

178. Brito VN, Oliveira CM, Lazari P, Sousa VRF. Aspectos epidemiológicos da leishmaniose visceral em Jaciara, Estado de Mato Grosso, Brasil, de 2003 a 2012. Rev Bras Parasitol Vet. 2014;23(1):63-68.

179. Furlan MBG. Epidemia de leishmaniose visceral no Município de Campo Grande-MS, 2002 a 2006. Epidemiol Serv Saúde. 2010;19(1):15-24.

180. Guerra JA, Barros MLB, Fé NF, Guerra MVF, Castellon E, Paes MG et al. Visceral Leishmaniasis among Indians of the State of Roraima, Brazil: clinical and epidemiologic aspects of the cases observed from 1989 to 1993. Rev Soc Bras Med Trop. 2004;37(4):305-11

181. Cardoso RM. Detecção molecular de espécies de Leishmania em mamíferos de unidades de conservação e entorno do Distrito Federal, Brasil. 63f. 2015. Tese (Doutorado em Medicina Tropical). Universidade de Brasília.

182. Brasil. Ministério da Saúde. Secretaria de Vigilância à Saúde - Sistema de informação de Agravos e Notificação - SINAN. [acesso em 10 jan 2015]. Disponível em: www.saude.gov.br/sinanweb.

183. Castellano RL. Resposta immune anti-Leishmania e mecanismos de evasão. Vitae Academia Biomédica Digital. 2005;25.

184. Muzio M, Bosisio D, Polentarutti N, D’amico G, Stoppacciaro A, Mancinelli R, Van’t Veer C, Penton-Rol G, Ruço LP, Allavena P, Mantovani A. Differential expression and regulation of toll-like receptors (TLR) in human leukocytes: selective expression of TLR3 in dendritic cells. J Immunol. 2000;164:5998-6004. 
185. Trinchieri G, Sher A. Cooperation of Toll-like receptor signals in innate immune defence. Nat Rev Immunol. 2007;7:179-190.

186. Kelsall BL, Biron CA, Sharma O, Kaye PM. Dendritic cells at the host-pathogen interface. Nat Immunol. 2002;3:699-702.

187. Reis e Sousa C. Toll-like receptors and dendritic cells: for whom the bug tolls. Semin Immunol. 2004;16:27-34.

188. Grazzinelli RT, Denkers EY. Protozoan encounters with Toll-like receptors signalling pathways: implications for host parasitism. Nat Rev Immunol. 2006;6:895-906.

189. Wiese M, Gorcke I. Homologues of LMPK, a mitogen-activated protein kinase from Leishmania mexicana, in different Leishmania species. Med Microbiol Immunol. 2001;190:19-22.

190. Turco SJ, Spath GF, Beverley SM. Is lipophosphoglycan a virulence factor? A surprising diversity between Leishmania species. Trends Parasitol. 2001;17:223-226.

191. Mottram JC, Brooks DR, Coombs GH. Roles of cysteine proteinases of trypanosomes and Leishmania in host-parasite interactions. Curr Opin Microbiol. 1998;1:455-60.

192. Yao C, Donelson JE, Wilson ME. The major surface-protease (MSP or GP63) of Leishmania spp . Biosynthesis, regulation of expression, and function. Mol Biochem Parasitol. 2003;132:1-16.

193. Hassan P, Fergusson D, Grant KM, Mottram JC. The CRK3 protein kinase is essential for cell cycle progression of Leishmania mexicana. Mol Biochem Parasitol. 2001;113:189-198.

194. Rittig MG, Bogdan C. Leishmania-Host-Cell interaction: Complexities and alternative views. Parasitol Today. 2000;16:292-7.

195. Handman E, Bullen DVR. Interaction of Leishmania with the host macrophage. Trends Parasitol. 2002;18:332-4.

196. Handman E, Spira DT. Growth of Leishmania amastigotes in macrophages from normal and immunemice. Z Parasitenk. 1977;53:75-81.

197. de Freitas JCC, Pinheiro DCSN. Aspectos celulares e moleculares da resposta imunitária a Leishmania spp. RPCV. 2010;105:573-6.

198. Jochim RC, Teixeira C. Leishmania commandeers the host inflammatory response through neutrophils. Trends Parasitol. 2009;25:145-7.

199. Bacellar O, Carvalho E. Imunopatogênese da leishmaniose visceral. Gaz Med Bahia. 2005; 75:24-34. 
200. Romão PRT, Dias RO, Cruz KK, Marques FCS, Monteiro MCM. Leishmaniose: resposta imune e mecanismos antioxidantes de escape. Revista de Pesquisa e Extensão em Saúde. 2007;3(1):1-10.

201. Zer R, Yaroslavski I, Rosen L, Warburg A. Effect of sandfly saliva on Leishmania uptake by murine macrophages. Int J Parasitol. 2001;31:810-814.

202. Saha S, Mondal S, Banerjee A, Ghose J, Bhowmick S, Ali N. Immune responses in kalaazar. Indian J Med Res. 2006;123(3):245-66.

203. Nascimento MD, Bezerra GFB, Bandeira Neto AP, da Silva LM, Bezerra JM, Viana GMC. Estudo comparativo de anticorpos IgG e IgE antiLeishmania como marcadores de infecção e doença em indivíduos de area endêmica de leishmaniose visceral, em São Luis, MA. Ver Soc Med Trop. 2006;39:39-41.

204. Atta AM, Correa J, Carvalho EM. Anti-leihmanial IgE antibodies a marker of active disease in visceral Leishmaniasis. Am J Trop Med Hyg. 1998;59:426-30.

205. Goto H, Prianti MG. Immunoactivation and immunopathogeny during active visceral Leishmaniasis. Rev Inst Med Trop. 2009;51:241-6.

206. Pace D. Leishmaniasis. J Infect. 2014;69(10-18).

207. Saporito L, Giammanco GM, De Grazia S, Colomba C. Visceral Leishmaniasis: hostparasite interactions and clinical presentation in the immunocompetent and in the immunocompressed host. Int J Infect Dis. 2013;17:572-6.

208. Badaró R, Carvalho EM, Orge MLGO, Teixeira RS, Rocha H. Imunidade humoral e celular em Indivíduos curados de Leishmaniose Visceral. Revista da Sociedade Brasileira de Medicina Tropical. 1985;18(2):77-83.

209. Santos-Gomes GM, Rosa R, Leandro C, Cortes S, Rão P, Silveira H. Cytokine expression. During the out-come of canine experimental infection by Leishmania infantum. Vet. Immunol Immunopathol. 2002;88:21-30.

210. Pastorino AC, Jacob CMA, Oselka GW, Carneiro-Sampaio MMS. Visceral Leishmaniasis: clinical and laboratorial aspects. J. Pediatr. 2002;78(2):120-127.

211. Muller K, Zandbergen GV, Hansen B, Laufs H, Jahnke N, Solbach W, et al. Chemokines, natural killer cells and granulocytes in the early course of Leishmania major infection in mice. Med. Microbiol. Immunol. 2001;190(1-2):73-6.

212. Laurenti, MD. Patologia e Patogenia das Leishmanioses. 140 f. São Paulo, 2010. Tese (Departamento de Patologia da Faculdade de Medicina). Universidade de São Paulo.

213. Andrade TM, Carvalho EM, Rocha H. Bacterial infections in patients with visceral Leishmaniasis. The Journal Infectious Diseases. 1990;162(1):1354-1359.

214. Partata AK. Epidemiologia da leishmaniose visceral humana em Araguaína (TO) e o diagnóstico sorológico da doença. São Paulo, 2010. Tese (Doutorado em Tecnologia 
Nuclear - Aplicações Energéticas e Nucleares). Instituto de Pesquisa Tecnologia Nuclear da Universidade de São Paulo-USP.

215. Braga ASC. Fatores associados à evolução clínica de leishmaniose visceral em crianças hospitalizadas em centro de referência de Belo Horizonte, 2001 a 2005. 78 fl. Tese de Mestrado do Programa de Pós-graduação em Ciências da Saúde da Faculdade de Medicina da Universidade Federal de Minas Gerais. 2007

216. Badaró R; Duarte MIS. Leishmaniose Visceral (Calazar). In: Veronesi, R; Focaccia, R (Eds). Tratado de Infectologia. 3.ed. São Paulo: Atheneu; 2005:1561- 90.

217. Baranwal AK, Mandal RN, Sing R. Fulminant hepatic failure complicating visceral Leishmaniasis in a apparently immunocompetent child. Indian $\mathbf{J}$ Pediatr. 2007;74(5):489- 91.

218. Salgado-Filho N. Estudo da ocorrência de imunocomplexos circulantes e ativação do sistema complemento em pacientes com forma aguda de Leishmaniose visceral. Tese de Mestrado (Escola Paulista de Medicina) São Paulo,1987.

219. Salgado-Filho N. Estudo da ocorrência de imunocomplexos circulantes e ativação do sistema do complemento em pacientes com a forma aguda da leishmaniose visceral. Dissertação (Escola Paulista de Medicina), São Paulo, 1987.

220. Caravaca F, Munõz A, Pizarro JL, Santamaria JS, Fernandez-Alonso J. Acute renal failure in visceral Leishmaniasis. American Journal of Nephrology. 1991;11(350-352).

221. Oliveira JM, Fernandes AC, Dorval MEC, Alves TP, Fernandes TD, Oshiro ET, Oliveira ALL. Mortalidade por leishmaniose visceral: aspectos clínicos e laboratoriais. Rev Soc Bras Med Trop. 2010;43:188-193.

222. Pintado V, Martin-Rabadan P, Rivera ML, Moreno S, Bouza E. Visceral Leishmaniasis in human immunodeficiency virus (HIV)-infected and non-HIV-infected patients. A comparative study. Medicine (Baltimore). 2001;80(1):54-73.

223. Berman JD. Human Leishmaniasis: clinical, diagnostic, and chemotherapeutic developments in the last 10 years. Clin Infect Dis. 1997;24:684-703.

224. Cruz I, Nieto J, Moreno J, Cañavate C, Desjeux P, Alvar J. Leishmania/HIV coinfections in the second decade. Indian J Med Res. 2006;123:357-88.

225. Badaró R, Carvalho EM, Rocha H, Queiroz AC, Jones TC. Leishmania donovani: an opportunistic microbe associated with progressive disease in three immunocompromised patients. Lancet. 1986;1: 647-9.

226. Alvarenga DG, Escalda PMF, Costa ASV, Monreal MTFD. Leishmaniose visceral: estudo retrospectivo de fatores associados a letalidade. Rev Soc Bras Med Trop. 2010;43:194-197. 
227. Nascimento M, Souza EC, da Silva LM, Leal PC, Cantanhede KL, et al. Prevalence of infection by Leishmania chagasi using ELISA (rK39 and CRUDE) and the Montenegro skin test in an endemic Leishmaniasis area of Maranhao, Brazil. Cad Saúde Pública. 2005;21:1801-1807.

228. Çelik Ü, Leblebisatan G, Alhan E, Aksaray N. Immune Hemolytic Anemia in Association with Visceral Leishmaniasis. J Pediatr Inf. 2007;1:36-8.

229. Kadivar, M.R, Kajbaf TZ, Karimi A, Alborzi A. Childhood visceral Leishmaniasis complicated by bacterial infections. East Mediterr Health J. 2000 Sep-Nov;6(5-6):87983.

230. Rey LC, Martins CV, Ribeiro HB, Lima AAM. Leishmaniose visceral americana (calazar) em crianças hospitalizadas de área endêmica. J Pediatr. 2005;81:73-78.

231. Gama MEA, Gomes CMC, Silveira FT, Laurenti MD, Goncalves EG, Silva AR da et al. Severe visceral Leishmaniasis in children: the relationship between cytokine patterns and clinical features. Rev Soc Bras Med Trop. 2013;46(6):741-745.

232. Maltezou HC, Siafas C, Mavrikou M, Spyridis P, Stavrinadis C, Karpathios T, et al. Visceral Leishmaniasis during childhood in Southern Greece. Clin Infect Dis 2000;31:1139-43.

233. GENARO, O. Parasitologia Humana. 10ª ed. Atheneu S.A, São Paulo. 2002:56-60.

234. Nuzum E, White F, Thakur C, Dietze R, Wages J, Grog M, et al. Diagnosis of symptomatic visceral Leishmaniasis by use of the polymerase chain reaction on patient blood. Journal of Infectious Diseases. 1995;171:751-754.

235. José FF, Silva IM da, Araújo MI, Almeida RP, Bacellar O, Carvalho EM Avaliação do poder sensibilizante da reação de Montenegro. Rev Soc Bras Med Trop. 2001;34(6): $537-42$.

236. Fagundes A, Antônio L, Schubach A, Marzochi KB, Fagundes A. Comparison between in vivo measurement of the Montenegro skin test and paper recording. Int J Dermatol. 2012;51:618-9.

237. Viana GMC, Nascimento MDSB, Diniz Neto JA, Rabelo EMF, Binda Júnior JR, Santos Júnior OM et al. Anti-Leishmania titers and positive skin tests in patients cured of kalaazar. Braz J Med Biol Res. 2011;44(1):62-65.

238. Bearmam, JE, Kleinman H, Glyer VV, Lacroix OM. A Study of Variability in Tuberculin Test Reading. Am Rev Respir Dis. 1964;90:913-9.

239. Sokal JE. Editorial: Measurement of delayed skin-test responses. N Engl J Med. 1975;293:501-502. 
240. Salles Gomes L. A intra-dermo-reacção de Montenegro na leishmaniose e outras pesquisas afins. Brasil-Medico. 1939:1079-1087.

241. Clemente WT, Rabello A, Faria LC, Peruhype-Magalhães V, Gomes LI, Silva TAM da. High Prevalence of Asymptomatic Leishmania spp. Infection Among Liver Transplant Recipients and Donors From an Endemic Area of Brazil. American Journal Transplant. 2014;14:96-101

242. Lemos EM, Carvalho, SFG, Corey R, Dietze R. Avaliação do Teste Rápido utilizando o Antígeno Recombinante k39 no Diagnóstico da Leishmaniose Visceral no Brasil. Rev Bras Soc Med Trop. 2003;36(2).

243. Pessoa SB, Pestana BR. A intradermo-reação de Montenegro nas campanhas sanitárias contra a leishmaniose. Arq Hig Saúde Pública. 1940:125-37.

244. Marink W, Costa CA, Magalhaes PA, Melo MN, Dias M, Oliveira Lima A, Michalick MS, Willians P 1979. A field trial of a vaccine against American dermal Leishmaniasis. Trans R Soc Trop Med Hyg 73: 385-387.

245. Boelaert M, El-Safi S, Hailu A, Mukhtar M, Rijal S, Sundar S. et al. Diagnostic tests for kala-azar: a multi-centre study of the freeze-dried DAT, rK39 strip test and KAtex in East Africa and the Indian subcontinent. Trans R Soc Trop Med Hyg. 2008;102:32-40.

246. Barbosa RNP, Corrêa ZJC, Jesus RCS de, Everdosa DR, Brandão JA, Coelho RN et al. Novas evidências sobre o valor diagnóstico da reação de imunofluorescência indireta e reação intradérmica de hipersensibilidade tardia na infecção humana por Leishmania (L.) infantum chagasi na Amazônia, Brasil. Rev Pan-Amaz Saude 2010;1(1):33-44.

247. Ritmeijer K, Dejenie A, Assefa Y, Hundie TB, Mesure J, Boots G, et al. A comparison of miltefosine and sodium stibogluconate for treatment of visceral Leishmaniasis in an Ethiopian population with high prevalence of HIV infection. Clin Infect Dis 2006;43:357-64.

248. Peruype-Magalhães V, Machado-de-Assis TS, Rabello A. Use of the Kala-Azar Detect ${ }^{\circledR}$ and IT-LEISH ${ }^{\circledR}$ rapid tests for the diagnosis of visceral Leishmaniasis in Brazil. Mem Inst Oswaldo Cruz. 2012;107(7):951-52.

249. Singh N, Singh RT, Sundar S. Novel mechanism of drugresistance in kala azar field isolates. J Infect Dis. 2003;188:600-607.

250. Lima-Júnior MSC, Andreotti R, Moraes ME, Durval C, Oshiro ET, Oliveira AG et al. Identificação de espécies de Leishmania isoladas de casos humanos em Mato Grosso do Sul por meio da reação em cadeia da polimerase. Rev Soc Bras Med Trop. 2009;42(3):303-8.

251. Ferroglio A, Romano A, Trisciuoglio AM, Poggib E, Chiggic P, Sacchia A. Characterization of Leishmania infantum strains in bood samples from infected dogs and 
humans by PCR-RFLP. Transactions of the Royal Society of Tropical Medicine and Hygiene. 2006;100:636-41.

252. Lachaud L, Marchergui-hammani S, Chabbert E, Dereure J, Dedet JP, Bastien P. Comparason os six PCR methods using peripheral blood for detection of canine visceral Leishmaniasis. Journal of Clinical Microbiology. 2002;40:210-15.

253. Paiva BR, Passos LN, Falquedo A, Malafronte RS, Andrade HF. Single step polymerase chain reaction (PCR) for the diagnosis of the Leishmania (Vianna) subgenus. Rev Inst Med Trop. 2004;46:335-8.

254. Rodgers MR, Popper SJ, Wirth DF. Amplification of kinetoplast as a tool in the detection and diagnosis of Leishmania. Exp. Parasitology . 1990;71:267-275.

255. Figueira LP, Pinheiro FG, Nogueira RW, Nery LCR, Mota KC, Franco AMR. Dinâmica da Leishmaniose Tegumentar no assentamento Iporá-AM, BR: II - Caracterização isoenzimática de isolados humanos de Leishmania spp. (Kinetoplástica: Trypanosomatidae). Rev Soc Bras Med Trop. 2008;41:194.

256. De Paula CDR, Sampaio JHD, Cardoso DR, Sampaio RNR. Estudo comparativo da eficácia de isotionato de pentamidina administrada em três doses durante uma semana e de $\mathrm{N}$-metil-glucamina $20 \mathrm{mgSbV} / \mathrm{kg} /$ dia durante vinte dias para o tratamento da forma cutânea da leishmaniose tegumentar americana. Rev Bras Soc Med Trop. 2003;36(3):365-71.

257. Sampaio RNR, Marsden PD, Furtado T, Sampaio JHD. Avaliação do tratamento da forma mucosa de Leishmaniose tegumentar americana com antimoniais pentavalentes. Anais Brasileiros de Dermatologia 664:189-192,1989.

258. Kirk R, MacDonald DR. Rare case trated with 4-4'diphenoxy-pentane. Annals of Tropical Medicine and Parasitology 34: 131, 1940.

259. Murray HW. Progress in treatment of a neglected disease: visceral Leishmaniasis. Expert Rev Anti-infect Ther. 2004;2:279-92.

260. Jain K, Jain NK. Vaccines for visceral Leishmaniasis. A review. Immunol Methods. $2015 \mathrm{Jul} ; 422: 1-12$.

261. Killick-Kendrick R, Killick-Kendrick M, Focheux C, Dereure J, Puech MP, Cadiergues MC. Protection of dogs from bites of phlebotomine sandflies by deltamethrin collars for control of canine Leishmaniasis. 1997 Apr;11(2):105-11.

262. Lucientes J. Laboratory observations on the protection of dogs from the bites of Phlebotomus perniciosus with Scalibor ${ }^{\circledR}$ ProtectorBands: preliminary results. In: Canine Leishmaniasis: an update. Proceedings of the International Canine Leishmaniasis Forum Barcelona, Spain. (Ed. R. Killick-Kendrick), Wiesbaden: Hoechst Roussel Vet 1999:92 -94 . 
263. Maroli M, Mizzoni V, SIRAGUSA C, D’ORAZI A D, GRADONI L. Evidence for am impacto $\mathrm{n}$ the incidence of canine Leishmaniasis by mass use of deltamethrinimpregnates dog collars in southern Italy. Med. and Vet. Ent. 15: 358 - 363, 2001.

264. Gavgani ASM, Hodjati MH, Mohite H, Davies CR. Effect of insecticide-impregnated dog collars on incidence of zoonotic visceral Leishmaniasis in Iranian children: a matched-cluster randomized trial. The Lancet 360: 374 - 379, 2002

265. Camargo-Neves VLF de, Rodas LAC, Junior CP. Avaliação da Efetividade da Utilização de Coleiras Impregnadas com Deltametrina a 4\% para o Controle da Leishmaniose Visceral Americana no Estado de São Paulo: Resultados Preliminares. Boletim Informativo Paulista. Informe Mensal sobre Agravos à Saúde Pública Dezembro, 2004;1(12). Disponível em: <http://www.cve.saude.sp.gov.br/agencia/bepa12_lva.htm>. Acesso em 30/10/2013.

266. Lane VFM, Junior VLP, Pereira LRM. Judicialização das Ações de Vigilância em Saúde: o caso da Leishmaniose Visceral. Tempus Actas de Saúde Coletiva. 2013;7(1):55-62.

267. Costa CHN. Caracterização e especulações acerca da urbanização da Leishmaniose visceral no Brasil. Cad Saúde Pública. 2008 Dez;24 (12):2959

268. TESH RB. Control of zoonotic Leishmaniasis: is it time to change strategies? American Journal of Tropical Medicine and Hygiene. 1995;52(3):287-292.

269. Almeida S., Medronho R. A., Werneck G. L. Identification of Risk Areas for Visceral Leishmaniasis in Teresina, Piaui State, Brazil. Am. J. Trop. Med. Hyg. 2011;84(5):681-7

270. Hasibeder G, Dye C, Carpenter J. Mathematical modelling and theory for estimating the basic reproduction number of canine Leishmaniasis. Parasitology. 1992;105,43-53.

271. Dye C. The logic of visceral Leishmaniasis control. Am J Trop Med Hyg. 1996;55:125130

272. Sala A. Integralidade e Atenção Primária à Saúde: avaliação na perspectiva dos usuários de unidade de saúde do município de São Paulo. Saude. Soc. 2011;20(4).

273. Gil MRR. Atenção primária,atenção básica e saúde da família: sinergias e singularidades no contexto brasileiro.Cad. De Saúde publica. 2006;22(6):1171. 
274. Luz ZMP, Schall V, Rabello A. Evaluation of a pamphlet on visceral Leishmaniasis as a tool for providing disease information to healthcare professionals and laypersons. Cad Saúde Pública. 2005;21:608-21.

275. Borges BKA, Silva JA da, Haddad JPA, Moreira EC, Magalhães DF, Ribeiro LML et al. Avaliação do nível de conhecimento e de atitudes preventivas da população sobre a leishmaniose visceral em Belo Horizonte, Minas Gerais, Brasil. Cad. Saúde Pública. 2008;24(4):777-84.

276. Ventura M, Simas L, Pepe VLE, Schramm FR. Judicialização da Saúde, acesso à justiça e a efetividade do direito à saúde. Physis. 2010:77-100.

277. Barata, R, Chieffi AL. Judicialização da política pública de assistência farmacêutica e equidade. Cad. Saúde Pública. 2009;25(8):1839-49.

278. Travassos C, Martins M. Uma revisão sobre os conceitos de acesso e utilização de serviços de saúde. Cad. Saúde Pública. 2004;20(2):190-8.

279. Brasil. Ministério da Saúde. Secretaria de Vigilância Sanitária. Parecer Técnico $n^{\circ}$ 22/2009-SVS/MS.

280. Brasil. Ministério da Saúde, Ministério da Agricultura, Pecuária e Abastecimento. Portaria Interministerial MS/MAPA no 1.426 de 11/07/2008.

281. Marques SB. Judicialização do Direito à Saúde. Revista do Direito Sanitário. São Paulo. 2008;9(2).

282. Barbosa MN, Carmo RF, Oliveira DCD, Silva GC, Luz ZMP. Atenção aos casos humanos de Leishmaniose visceral no âmbito da atenção primária à saúde em município da região metropolitana de Belo Horizonte. Revista de APS. 2013;16(3): 234-41. 


\section{COMITÊ DE ÉTICA EM

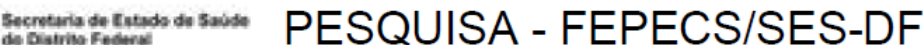

\section{PARECER CONSUBSTANCIADO DO CEP}

\section{DADOS DO PROJETO DE PESQUISA}

Título da Pesquisa: Avaliação das politicas de controle da leishmaniose visceral com ênfase na integralidade

Pesquisador: Viviane Fragoso de Moura Lane

Área Temática:

Versão: 3

CAAE: 07728713.9 .0000 .5553

Instituição Proponente: DISTRITO FEDERAL SECRETARIA DE SAUDE

Patrocinador Principal: Financiamento Próprio

\section{DADOS DO PARECER}

Número do Parecer: 820.097

Data da Relatoria: 06/10/2014

Apresentação do Projeto:

Sem alterações em relação ao Parecer número 204.384 de 25/02/2013.

Objetivo da Pesquisa:

Sem alterações em relação ao Parecer número 204.384 de 25/02/2013.

Avaliação dos Riscos e Benefícios:

Sem alterações em relação ao Parecer número 204.384 de 25/02/2013.

Comentários e Considerações sobre a Pesquisa:

Sem alterações em relação ao Parecer número 204.384 de 25/02/2013.

Considerações sobre os Termos de apresentação obrigatória:

Sem alterações em relação ao Parecer número 204.384 de 25/02/2013.

Recomendações:

Conclusões ou Pendências e Lista de Inadequações:

Pendencias resolvidas.

Situação do Parecer:

Aprovado

Endereço: SMHN 2 Qd 501 BLOCO A - FEPECS

Bairro: ASA NORTE

UF: DF

Município: BRASILIA

Telefone: (61)3325-4955

Fax: (33)3325-4955

E-mail: comitedeetica.secretaria@gmail.com 


\section{APÊNDICE I}

Estudo 2-Questionário aplicado aos profissionais de saúde das UBS's.

\section{FICHA DE COLETA DE DADOS}

\section{ATENÇÃO AOS CASOS DE LV NA APS}

Ficha №

Data da coleta de dados

I-Dados Pessoais:

1. Nome: (opcional)

2. Sexo: feminino ( ) masculino( )

3. Ano de conclusão do curso de graduação

4. Unidade de Atendimento

5. Especialidade Médica

\section{II- A respeito da Leishmaniose visceral-LV}

1. Em sua opinião, qual a importância epidemiológica da LV na região da Fercal?

( ) Deve-se ao grande número de casos e letalidade na região.

( ) convívio com as condições propícias para a transmissão da doença, tais como o cão doméstico e o vetor (Lutzomyia longipalpis).

( ) Desinformação sob a doença.

( ) Não há casos de LV na região.

\section{Qual a conduta adotada em um caso confirmado?}

( ) Encaminhamento para o serviço de referência no tratamento de LV

( ) Contato com a vigilância epidemiológica

( ) Tratamento do paciente

( ) Encaminhamento à internação.

3. Quantos casos de LV que atendeu nessa unidade de saúde?

( ) Nenhum caso ( ) Três casos ( ) um caso

( ) Mais de cinco casos ( ) dois casos

4. Há fluxos para informações e exames para diagnóstico e tratamento de casos de LV?

( ) $\operatorname{Sim}()$ ignorado

( ) Não 
6. Disponibilidade de exames para diagnóstico e acompanhamento dos casos de LV

( ) $\operatorname{Sim}($ ) ignorado

( ) Não

7. Se sim, quais são os exames disponíveis?

( ) Sorologia ( ) Função hepática ( ) ultrassom

( ) Hemograma ( ) Eletrocardiograma

III- Acompanhamento dos pacientes com leishmaniose visceral

1. Em sua opinião, qual a importância de realizar exames pré-tratamento e de acompanhamento dos casos de LV?

( ) Toxidade do tratamento

( ) Avaliação da gravidade do caso

( ) Avaliação da resistência

( ) Comprovação pela técnica de intradermorreação de Montenegro (IDRM).

2. Quais os exames que são importantes após o tratamento de LV?

( ) Hemograma ( ) Exames clínicos

( ) Função hepática ( ) Mielograma

( ) Sorologia ( ) Outros

IV- Condições de atendimento aos pacientes na Unidade de Saúde

1. Em sua opinião a Unidade de Saúde oferece infraestrutura para o diagnóstico e acompanhamento dos casos de LV na região?

( ) Sim ( ) ignorado

( ) Não

2. A equipe de saúde recebe cursos de capacitação para atender os casos de LV?

( ) Sim ( ) Não ( ) ignorado

3. Em sua opinião, a atenção primária apresenta um papel relevante no acompanhamento e diagnósticos dos casos de LV?

( ) Sim ( ) Não ( ) ignorado 


\section{APÊNDICE II}

Estudo 3- Questionário aplicado aos moradores da região administrativa da região administrativa da Fercal.

\section{FICHA DE COLETA DE DADOS}

\section{CASOS DE LV MONTENEGRO POSITIVO}

Ficha №

Data da coleta de dados

1. Dados Pessoais:

Nome:

Idade:

Sexo: Masculino ( ) Feminino ( )

Endereço:

CEP:

Comunidade de residência:

DF.

2. Possui residência própria?

Sim ( ) Não( )

3. Qual seu nível de escolaridade?

( ) Nenhum ( ) Superior

( ) Fundamental ( ) Não sabe

( ) Médio

4. Dados da moradia:

Tempo de moradia anos.

Situação: Própria ( ) Alugada ( ) Cedida ( ) Outros ( ) Material: Alvenaria ( ) Madeira ( ) Pau a pique ( ) Outros ( )

Descrever:

3.3. Número de moradores:

4. Renda familiar: 
( ) Até 1 salário mínimo ( ) de 3 a 5 salários mínimos

( ) de 1 a 3 salários mínimos

5. Faz uso de algum medicamento?

( ) $\operatorname{Sim}$ ( ) Não

9. Avaliação do estado nutricional:

9.1. Qual seu peso? $\mathrm{Kg}$

\section{Á respeito da LV:}

10. Já ouviu falar em calazar ou Leishmaniose visceral (LV)?

$\operatorname{Sim}($ ) Não ( )

10.1. Há algum caso de calazar ou LV na família? Sim ( ） Não ( )

10.3. Você conhece alguns desses sintomas típicos do calazar ou LV?

Emagrecimento ( ) inchaço no fígado e/ou baço ( ) Outros ( )

Quais?

Você conhece como é transmitido o calazar ou LV?

cão doente ( ) mosquito ( ) Não se sabe ( )

Você conhece o nome do mosquito transmissor?

Sim ( ) mosquito palha ( ) tatuquira ( ) cangalhinha ( ) birigui ( ).

Não ( )

10.4. Reservatório:

Presença de animais na casa:

Não ( ) Sim ( )

Qual ?

10.5. Se forem cães, quantos são $1(\quad) 2(\quad) \quad(\quad)$ mais de 2.

10.6. Em caso da presença de animais, onde são criados?

Dentro de casa ( ) fora de casa ( ) Dentro e fora de casa ( )

Cães doentes (sorologia positiva) $\operatorname{Sim}($ ) Não ( )

Após a positividade desse exame o cão ainda convive com a família? Sim ( ) Não( )

Se não, quais foram às medidas adotadas para eliminação desse cão? 
Descrever o tipo:

\section{Características gerais da comunidade:}

11.1 Em sua opinião, quais são os principais problemas em sua comunidade?

a) saneamento básico ( )

b) falta de atendimento à saúde ( )

c) Disposição das casas próximas a vegetação ( )

11.2 Em relação ao saneamento básico, responda:

11.3 Há coleta de lixo na comunidade?

Sim ( ) Não ( )

11.4 Provisão de água:

Rede pública ( ) Córrego / Riacho/Lago ( ) Poço artesiano ( ) 13. Faz uso de água potável em casa?

Sim ( ) Não( )

14. É realizado algum tipo de programa de controle de pragas, mosquitos e de outros patógenos na comunidade que reside?

$\operatorname{Sim}($ ) Não( )

\section{Medidas de controle:}

15.1. Encaminhamento à Unidade básica de Saúde Sim （ ） Não ( )

15.2. Quais foram às providências adotadas na Unidade básica de Saúde?

a) Visita domiciliar (retorno) Sim ( ) Não ( )

b) Retirada do cão doente do domicilio? $\operatorname{Sim}(\quad)$ Não ( )

c) Foi realizada uma avaliação clinica? Sim ( ) Não ( )

d) Outros tipos de monitoramento? Sim ( ) Não ( )

Qual?

Outros tipos de monitoramento 


\section{APÊNDICE III}

\section{Termo de Consentimento Livre e Esclarecido-TCLE: Participantes do Estudo 2}

\section{Termo de Consentimento Livre e Esclarecido - TCLE}

O (a) Senhor (a) está sendo convidado (a) a participar do projeto: avaliação das políticas de controle da Leishmaniose Visceral Humana, com ênfase na integralidade da atenção.

Esta pesquisa tem como objetivo analisar o conhecimento, práticas profissionais e a atenção aos casos diagnosticados em um território endêmico do Distrito Federal, no âmbito da atenção primária à saúde.

O (a) senhor(a) receberá todos os esclarecimentos necessários antes e no decorrer da pesquisa e lhe asseguramos que seu nome não aparecerá sendo mantido o mais rigoroso sigilo através da omissão total de quaisquer informações que permitam identificá-lo(a).

A sua participação será através de um questionário (ou entrevista) que o(a) senhor(a) deverá responder nas dependências das unidades básicas de saúde, o (a) qual está lotado. Não existe obrigatoriamente, um tempo pré-determinado, para responder o questionário. Será respeitado o tempo de cada um para respondê-lo. Informamos que o(a) Senhor(a) pode se recusar a responder qualquer questão que lhe traga constrangimento, podendo desistir de participar da pesquisa em qualquer momento sem nenhum prejuízo para o(a) senhor(a).

Os resultados da pesquisa serão divulgados no Programa de Pós-graduação em Ciências Médicas da Universidade de Brasília, podendo ser publicados posteriormente. Os dados e materiais utilizados na pesquisa ficarão sobre a guarda do pesquisador.

Se o(a) Senhor(a) tiver qualquer dúvida em relação à pesquisa, por favor telefone para: Viviane Fragoso de Moura Lane na Universidade de Brasília-UNB. Telefone: (61) 98602885 nos horários de $08 \mathrm{hs}$ as $12 \mathrm{hs}$ e de $14 \mathrm{hs}$ as $18 \mathrm{hs}$.

Este projeto foi Aprovado pelo Comitê de Ética em Pesquisa da SES/DF. As dúvidas com relação à assinatura do TCLE ou os direitos do sujeito da pesquisa podem ser obtidos através do telefone: (61) 3325-4955.

Este documento foi elaborado em duas vias, uma ficará com o pesquisador responsável e a outra com o sujeito da pesquisa.

Nome / assinatura

Pesquisador Responsável

Nome e assinatura Brasília, de de 


\section{APÊNDICE IV}

Termo de Consentimento livre e Esclarecimento - TCLE: Participantes do Estudo 3

\section{Termo de Consentimento Livre e Esclarecido - TCLE}

Você está sendo convidado (a) a participar do projeto: avaliação das políticas de controle da Leishmaniose Visceral Humana, com ênfase na integralidade da atenção.

Esta pesquisa tem como objetivo investigar a evolução clínica de pacientes que apresentaram o teste Montenegro positivo, residentes da região administrativa da Fercal- DF.

Você receberá todos os esclarecimentos necessários antes e no decorrer da pesquisa e lhe asseguramos que seu nome não aparecerá sendo mantido o mais rigoroso sigilo através da omissão total de quaisquer informações que permitam identificá-lo(a)

A sua participação será por meio de uma entrevista, durante uma visita domiciliar. Não existe obrigatoriamente, um tempo pré-determinado, para responder as questões ao pesquisador envolvido. Informamos que você pode se recusar a responder qualquer questão que lhe traga constrangimento, podendo desistir de participar da pesquisa em qualquer momento sem nenhum prejuízo.

Os resultados da pesquisa serão divulgados no Programa de Pós-graduação em Ciências Médicas da Universidade de Brasília, podendo ser publicados posteriormente. Os dados e materiais utilizados na pesquisa ficarão sobre a guarda do pesquisador.

Caso tenha alguma dúvida em relação à pesquisa, por favor, telefone para: Viviane Fragoso de Moura Lane na Universidade de Brasília-UNB. Telefone: (61) 98602885 nos horários de $08 \mathrm{hs}$ as $12 \mathrm{hs}$ e de $14 \mathrm{hs}$ as $18 \mathrm{hs}$.

Este projeto foi Aprovado pelo Comitê de Ética em Pesquisa da SES/DF. As dúvidas com relação à assinatura do TCLE ou os direitos do sujeito da pesquisa podem ser obtidos através do telefone: (61) 3325-4955.

Este documento foi elaborado em duas vias, uma ficará com o pesquisador responsável e a outra com o sujeito da pesquisa.

Nome / assinatura

Pesquisador Responsável

Brasília, de de 